\title{
Um Sistema Baseado em \\ Conhecimento para Auxiliar no \\ Processo de Alocação de Rins
}

José Augusto Baranauskas

\author{
Orientação: \\ Profa. Dra. Maria Carolina Monard
}

Dissertação apresentada ao Instituto de Ciências Matemáticas de São Carlos - USP, como parte dos requisitos para obtenção do título de Mestre em Ciências - Área: Ciências de Computação e Matemática Computacional.

Trabalho realizado dentro do projeto de pesquisa apoiado pela FAPESP, Processo № 92/2151-8.

USP - São Carlos

Novembro de 1993 
Aos meus pais e à minha irmã.

Diante da vastidão do espaço e da imensidão do tempo é uma alegria, para mim, partilhar um planeta e uma época com eles. 
Não é no espaço que devo procurar a minha dignidade, mas na direção do meu pensamento. Não deverei tê-la mais se possuir mundos. Pela amplidão, o universo me envolve e me traga como um átomo; pelo pensamento eu compreendo o mundo.

Blaise Pascal, Pensées.

Deus é capaz de criar as partículas de matéria de vários tamanhos e feitios... e talvez de diferentes divindades e forças $e$, assim, variar as leis da Natureza e fazer mundos de vários tipos em várias partes do Universo. Pelo menos, não vejo nada de contraditório nisso.

Isaac Newton, Óptica.

Vivo cada dia como se fosse viver para sempre. E também vivo cada dia preparado para o fim, antevendo o futuro, esteja ele a um ou a vinte anos de distância. As pessoas que vivem no futuro permanecem jovens, qualquer que seja sua idade.

Albert Bruce Sabin. 
A juventude não é um periodo da vida; a juventude é um estado de espirito, um efeito da vontade, uma qualidade da imaginação, uma intensidade emotiva, uma vitória do valor sobre a timidez, do gosto pela aventura sobre o amor ao conforto. Alguém não se torna velho por haver vivido um certo número de anos; torna-se velho porque desertou dos ideais. Os anos enrugam a pele, mas a renúncia a um ideal enruga a alma. As preocupações, as dúvidas, os temores $e$ as desesperanças são os inimigos que, lentamente, nos fazem vergar para o chão e nos convertem em pó antes da morte. Jovem é o que deslumbra $e$ se maravilha... o que pergunta como menino

- $E$ depois ? Jovem é o que desafia os acontecimentos e encontra alegrias no jogo da vida. As provas galvanizam-no; os fracassos o tornam mais forte, as vitórias o tornam melhor.

Serás tão jovem como tua fé, tão velho como tuas dividas, tão jovem como a confiança que tenhas em ti, tão velho como tuas desesperanças $e$ mais velho ainda como o teu abatimento. Permanecerás jovem, tanto quanto permaneceres verdadeiramente generoso, tanto quanto sentires - entusiasmo de dar alguma coisa de ti: pensamentos, palauras, amor; tanto quanto o fato de dar alguma coisa te der a impressão de receber; e, por conseguinte, que sempre estás devendo e desejando dar mais. Permanecerás jovem enquanto fores receptivo a tudo quanto é belo, bom e grandioso, podendo desfrutar das mensagens da natureza, do homem $e$ do infinito. Se um dia, qualquer que seja tua idade, teu coração for mordido pelo pessimismo, torturado pelo egoísmo, roído pelo cinismo, que Deus tenha piedade de tua alma de velho.

General Douglas MacArthur. 


\section{Agradeço}

à Maria Carolina, pela orientação a mim proporcionada desde o início desta dissertação, pelo incentivo, dedicação ao trabalho; partilhar de sua amizade enriqueceu minha existência;

ao Prof. Dr. Agenor, pelo amor dedicado ao trabalho e às pessoas, pelo precioso tempo dispensado no auxílio e revisão das versões preliminares desta dissertação e por conceder-me a oportunidade de realizar um trabalho que proporcionou-me alegria e satisfação;

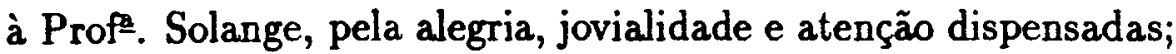

à Prof ${ }^{2}$. Dr ${ }^{\mathrm{a}}$. Neide, pelo respeito e altivez a mim concedidos;

à Roseli, com carinho especial;

à Ana Paula, Rita, Roseli Maria e Alida pela amizade e apoio;

à Beth e Laura, pela solicitude e carinho com que tratam a todos;

à Giselda, Gislene, Maria, Sandra, Rose e, especialmente à Silvana, pelo afeto e alegria que proporcionam aos usuários da biblioteca;

ao Marco, pela dedicação demonstrada aos usuários do setor de fotocópias;

à Ângela e à Regina, pelo carinho que tratam as pessoas e dedicação que proporcianam aos pacientes;

à minha família pelo apoio, carinho e compreensão pelo tempo que deixei de dedicar-lhe;

à todos que, de uma forma ou outra, contribuíram para a realização deste trabalho e

à Deus, a Quem devo minha existência e sem $\mathrm{O}$ Qual nada seria possível. 


\section{Resumo}

O objetivo deste trabalho é o de apresentar o desenvolvimento e a implementação de um sistema para auxílio, aos usuários da área médica, no processo de alocação de rins a serem transplantados em pacientes com problemas renais.

A idéia básica do sistema desenvolvido é a de utilizar um Sistema de Base de Dados - para manter e gerenciar as informações relevantes para o processo de alocação de rins'- e um Sistema Baseado em Conhecimento - responsável especificamente pelo processo de alocação.

Durante a fase de desenvolvimento, contou-se com o auxilio do especialista no domínio de transplantes renajs, Prof. Dr. Agenor Ferraz, médico e docente do Hospital das Clínicas da Faculdade de Medicina de Ribeirão Preto - USP. Buscou-se, também, utilizar as normas definidas pelo Protocolo São Paulo Interior Transplante. 


\section{Conteúdo}

1 Introdução 1

1.1 Considerações Iniciais . . . . . . . . . . . . . . . 1

1.2 Motivação do Trabalho ... . . . . . . . . . . . 2

1.3 Organização do Trabalho ................. 5 5

2 Sistemas de Base de Dados e Sistemas Baseados em Conhecimento 7

2.1 Considerações Iniciais . . . . . . . . . . . . . . 7

2.2 Sistemas de Base de Dados . . . . . . . . . . . . 7

2.3 Sistemas Baseados em Conhecimento . . . . . . . . . . 12

2.3.1 Sistemas Especialistas ............... 15

2.3.2 Componentes Básicos . . . . . . . . . . . 16

2.4 Bases de Conhecimento versus Bases de Dados . . . . . . . . 18

2.5 Considerações Finais . . . . . . . . . . . . . . 21

3 Interações entre Sistemas de Base de Dados e Sistemas Baseados em Conhecimento

3.1 Considerações Iniciais . . . . . . . . . . . . . . 22

3.2 Formas de Interação entre SBCs e SBDs . . . . . . . . . . 23 
3.2 .1 SBD Inteligente $\ldots \ldots \ldots \ldots \ldots \ldots \ldots$

$3.2 .2 \quad$ SBC Melhorado . . . . . . . . . . . . 25

3.2 .3 Comunicação Intersistemas . . . . . . . . . . . 27

3.3 Consideraçôes Finais $\ldots \ldots \ldots \ldots \ldots \ldots$

4 O Sistema SPIT

4.1 Considerações Iniciais . . . . . . . . . . . . 31

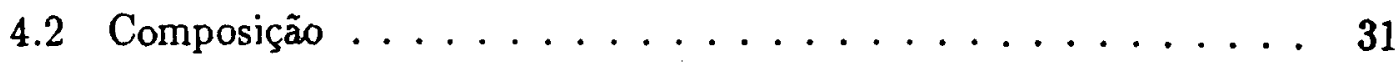

4.3 Considerações Finais $\ldots \ldots \ldots \ldots \ldots \ldots \ldots \ldots$

5 Fatores Considerados na Alocação de Rins 36

5.1 Considerações Iniciais . . . . . . . . . . . . . 36

5.2 Agrupando os Fatores $\ldots \ldots \ldots \ldots \ldots \ldots \ldots$

5.3 Fatores Primários . . . . . . . . . . . 38

5.3.1 Grupo $A B O($ Grupo Sangüíneo) $\ldots \ldots \ldots \ldots \ldots . \ldots 39$

5.3 .2 Cross-Match . . . . . . . . . . . . 41

$5.3 .3 \quad$ HLA $\ldots \ldots \ldots \ldots \ldots \ldots \ldots \ldots \ldots \ldots \ldots$

5.4 Fatores Secundários . . . . . . . . . . . . 47

5.4 .1 Transfusões $\ldots \ldots \ldots \ldots \ldots \ldots \ldots \ldots \ldots$

5.4 .2 Retransplantes $\ldots \ldots \ldots \ldots \ldots \ldots \ldots \ldots$

5.4 .3 Painel $\ldots \ldots \ldots \ldots \ldots \ldots \ldots \ldots \ldots \ldots$

5.4 .4 Gestagóes . . . . . . . . . . . . . . 49

5.4.5 Distância entre Doador e Receptor $\ldots \ldots \ldots \ldots$. . 49

5.5 Fatores Terciários . . . . . . . . . . . . 50

5.5 .1 Tempo de Hemodiálise $\ldots \ldots \ldots \ldots \ldots \ldots \ldots$ 
5.5 .2 Urgência Médica $\ldots \ldots \ldots \ldots \ldots \ldots \ldots$

5.5.3 Idade do Receptor $\ldots \ldots \ldots \ldots$. . . . . . . . 51

5.5.4 Tempo de Espera do Receptor por um Órgão . . . . . . 51

5.6 Considerações Finais $\ldots \ldots \ldots \ldots \ldots \ldots \ldots$

6 O Processo de Alocação de Órgãos 53

6.1 Considerações Iniciais . . . . . . . . . . . . . 53

6.2 Regras para a Alocação de Rins . . . . . . . . . . 54

6.3 Fatores Primários . . . . . . . . . . . . . 54

$6.3 .1 \quad$ Grupo $A B O \ldots \ldots \ldots \ldots \ldots \ldots \ldots \ldots$

6.3.2 Cross-Match $\ldots \ldots \ldots \ldots \ldots \ldots \ldots \ldots \ldots$

6.3.3 $H L A \ldots \ldots \ldots \ldots \ldots \ldots \ldots \ldots \ldots \ldots$

6.4 Fatores Secundários . . . . . . . . . . . . . 57

6.4.1 Transfusões $\ldots \ldots \ldots \ldots \ldots \ldots \ldots \ldots \ldots$

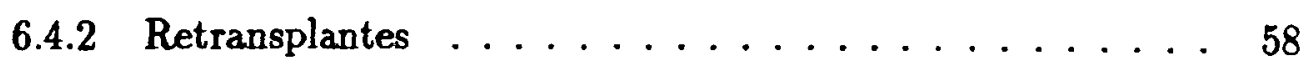

6.4 .3 Painel $\ldots \ldots \ldots \ldots \ldots \ldots \ldots \ldots \ldots \ldots$

6.4.4 Gestações . . . . . . . . . . . . . . 59

6.4.5 Distância entre Doador e Receptor . . . . . . . . 59

6.5 Fatores Terciários . . . . . . . . . . . . . . 59

6.5 .1 Tempo de Hemodiálise $\ldots \ldots \ldots \ldots \ldots \ldots$

6.5 .2 Urgência Médica . . . . . . . . . . . 60

6.5.3 Idade do Receptor $\ldots \ldots \ldots \ldots \ldots \ldots$

6.5.4 Tempo de Espera do Receptor por um Órgão . . . . . 61

6.6 Estrutura das Regras em Prolog . . . . . . . . . . . 61

6.7 Consideraşões Finais $\ldots \ldots \ldots \ldots \ldots \ldots \ldots \ldots$ 
7.1 Considerações Iniciais . . . . . . . . . . . . . . 65

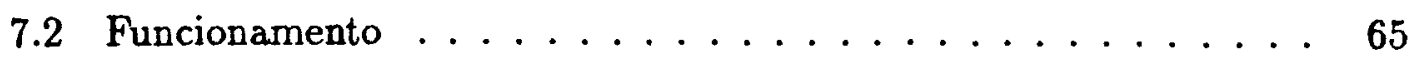

7.3 Ambiente de Desenvolvimento do SBD . . . . . . . . 70

7.4 Ambiente de Desenvolvimento do SBC . . . . . . . . 71

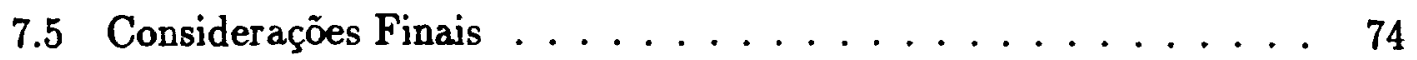

8 Exemplos de Funcionamento do Sistema $\mathcal{O R I O N} \quad 75$

8.1 Considerações Iniciais . . . . . . . . . . . . . . . 75

8.2 O SBD de $\mathcal{O R I O N} \ldots \ldots \ldots \ldots \ldots \ldots \ldots$

8.2.1 Menus Disponíveis . . . . . . . . . . 77

$8.3 \quad$ O SBC de ORION $\ldots \ldots \ldots \ldots \ldots \ldots \ldots \ldots \ldots$

8.3.1 Menus Disponiveis . . . . . . . . . . . . 92

8.4 Considerações Finais $\ldots \ldots \ldots \ldots \ldots \ldots \ldots$

9 Conclusões 100

9.1 Considerações Iniciais . . . . . . . . . . . . . . . . 100

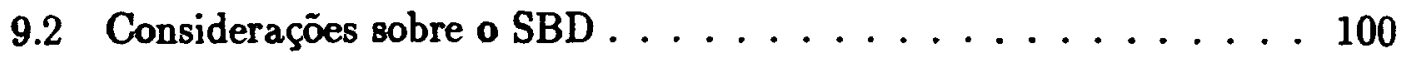

9.3 Considerações sobre o SBC . . . . . . . . . . . . 101

9.3.1 Ferramentas . . . . . . . . . . . . . . 102

9.4 Trabalhos Futuros . . . . . . . . . . . . . 103

9.4.1 Extensões no Sistema de Base de Dados . . . . . . . . 103

9.4.2 Extensões no Sistema Baseado em Conhecimento . . . . 104

9.5 Considerações Finais . . . . . . . . . . . . . . 104

$\begin{array}{ll}\text { Referências } & 106\end{array}$ 
B Projeto do Sistema de Base de Dados

B.1 Consideraçóes Iniciais . . . . . . . . . . . . . . . . . . . 117

B.2 Sobre JSD . . . . . . . . . . . . . . . . 117

B.3 Escolha das Entidades e Ações . . . . . . . . . . . . . . 119

B.4 Estruturação Cronológica das Ações . . . . . . . . . . . . . . 123

B.5 Construção do Modelo Inicial . . . . . . . . . . . . . . . 127

B.6 Adição de Funções . . . . . . . . . . . . . . . . . . 128

B.7 Articulação Temporal . . . . . . . . . . . . . . . . 131

B.8 Projeto da Implementação do Sistema . . . . . . . . . . . 133

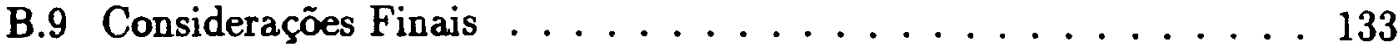




\section{Lista de Figuras}

2.1 Dependência entre Aplicação e Arquivo . . . . . . . . 8

2.2 Sistema Gerenciador de Arquivos . . . . . . . . . . 9

2.3 Sistema Gerenciador de Base de Dados . . . . . . . . . . 10

2.4 Sistema de Base de Dados . . . . . . . . . . . . . 11

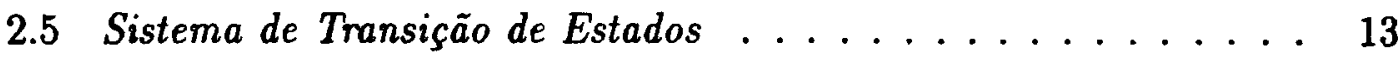

$2.6 I A, S B C s$ e $S E s \ldots \ldots \ldots \ldots \ldots \ldots \ldots \ldots \ldots$

2.7 Sistema Baseado em Conhecimento . . . . . . . . . . 16

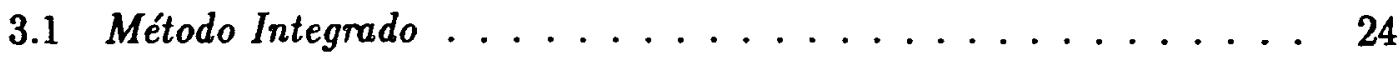

3.2 Método de Filtragem Dedutiva . . . . . . . . . . . . 24

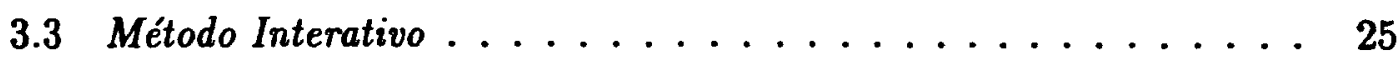

3.4 Extensão de Linguagem. . . . . . . . . . . . 26

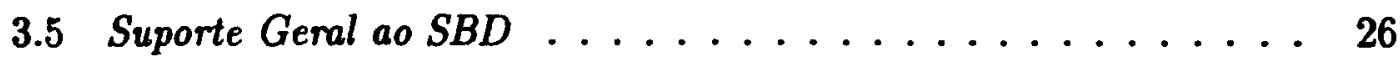

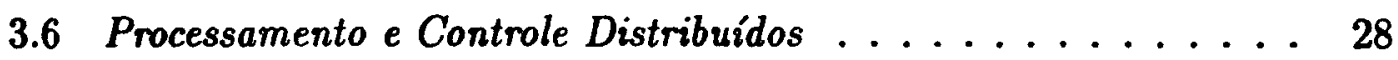

3.7 Processamento e Controle Locais. . . . . . . . . . . . . . 28

3.8 Processamento Distribuído Controlado por um Subsistema Independente. . . . . . . . . . . . . . . 29

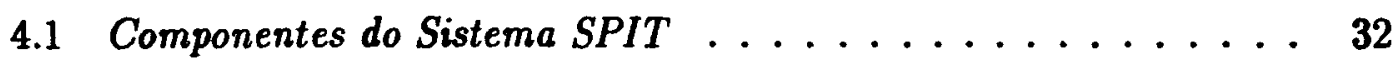

4.2 Ciclo de Vida de um Receptor no Sistema SPIT . . . . . . . 34 
5.1 Fatores Considerados na Alocação de Receptores . . . . . . . 38

5.2 Célula Mostrando um Par de Cromossomos Homólogos . . . . . 43

5.3 Herança de Haplótipos HLA . . . . . . . . . . . . 45

6.1 Regra Inicial do Processo de Alocação. . . . . . . . . . . . 62

6.2 Regra para os Fatores Primários. . . . . . . . . . . . 63

7.1 O Sistema $\mathcal{O} R \mathcal{I O N} \ldots \ldots \ldots \ldots \ldots \ldots$

7.2 Modelo Entidade-Relacionamento de $\mathcal{O R I O N}$. . . . . . . 71

7.3 Ambiente para Auxiliar a Construção de Núcleos Específicos . . 72

8.1 Tela de Apresentação . . . . . . . . . . . . . 76

8.2 Autenticação do Usuário . . . . . . . . . . . . 76

8.3 Menu Principal . . . . . . . . . . . . . . . 77

8.4 Menu Receptor ...................... 78

8.5 Cadastro de Receptor não Preenchido . . . . . . . . . . 79

8.6 Mensagem de Erro Exibida Quando o Sexo é Difenente de ' $M$ ' ou ' $F$ ' 79

8.7 Cadastro de um Receptor . . . . . . . . . . . . . . 80

8.8 Janela de Aviso . . . . . . . . . . . . . . . . 80

8.9 Suspensão de Receptor ................... 82

8.10 Consulta às Suspensões de um Receptor . . . . . . . . . . . . 82

8.11 Cadastro de Doador. . . . . . . . . . . . . 83

8.12 Menu Hospital. . . . . . . . . . . . . . . . . 83

8.13 Alteração de Hospital . . . . . . . . . . . . . . 84

8.14 Alteração de Parâmetros ................. 85

8.15 Seleção de Receptores . . . . . . . . . . . . . . 85 
8.16 Opções para Seleção de Receptores na Construção de Gráfico . . 86

8.17 Gráfico de Distribuição de HLA de um Doador Comparado com o HLA da População de Receptores . . . . . . . . . . . . 87

8.18 Gráfico de Distribuição da Porcentagem de PRA na População de Receptores.................... 87

8.19 Freqüência dos loci HLA na População de Receptores . . . . . 88

8.20 Gráfico de Freqüência dos loci HLA na População de Receptores (Sem Conectar as Linhas) . . . . . . . . . . . . 88

8.21 Gráfico de Freqüência dos loci HLA na População de Receptores (Linhas Conectadas) ................ 89

8.22 Consulta aos Acessos de um Usurío no Sistema . . . . . . . . . 90

8.23 Tela de Apresentação . . . . . . . . . . . . . . 91

8.24 Menu Principal .................... 91

8.25 Verificando os Fatores Utilizados na Alocação de Rins. . . . . . 93

8.26 Verificando todos os Fatores Disponiveis. . . . . . . . . 93

8.27 Alterando os Fatores Utilizados na Alocação de Rins. . . . . . . 94

8.28 Selecionando Receptores. . . . . . . . . . . . . . . 94

8.29 Pergunta feita ao Usuário. . . . . . . . . . . . . . 95

8.30 Usuário Questiona "por que" o Sistema Necessita uma Informação. 96

8.31 Usuário Questiona novamente "por que" o Sistema Necessita uma Informação. ..................... 96

8.32 Pontuação dos Receptores. . . . . . . . . . . . . . . . 97

8.33 Receptores Selecionados par Cross-Match. . . . . . . . . . 97

8.34 Receptores Desempatados. . . . . . . . . . . . . 98

8.35 Explicação de Como o Sistema chegou a uma Solução . . . . . . 98

B.1 JSD: Visão Geral . . . . . . . . . . . . . . 118 
B.2 Hospital: Diagrama de Estrutura Cronológica . . . . . . . 124

B.3 Suspensão de Hospital: Diagrama de Estrutura Cronológica . . . 124

B.4 Receptor: Diagrama de Estrutura Cronológica . . . . . . . . 125

B.5 Suspensão de Receptor: Diagrama de Estrutura Cronológica . . . 125

B.6 Doador: Diagrama de Estrutura Cronológica . . . . . . . . 126

B.7 Transplante: Diagrama de Estrutura Cronológica. . . . . . . 126

B.8 Diagrama de Especificação do Sistema: Modelo Inicial. . . . . . 129

B.9 Diagrama de Especificação do Sistema: Processos Funcionais . . 130

B.10 Projeto da Implementação do Sistema . . . . . . . . . . . . . 132 


\section{Lista de Tabelas}

2.1 Alguns Sistemas Gerenciadores de Base de Dados . . . . . . . . 12

2.2 Alguns Sistemas Especialistas . . . . . . . . . . . 18

2.3 Propostas para a Distinção entre uma $B D$ e uma $B C$. . . . . 19

5.1 Esquema das Possíveis Transfusões entre os Grupos Sangüíneos . 40

9.1 Ferramentas de Apoio e Shells . . . . . . . . . . . . 102

B.1 Entidades e Ações do Sistema $\mathcal{O R I O N}$. . . . . . . . . . 121 


\section{Capítulo 1}

\section{Introdução}

\subsection{Considerações Iniciais}

Há vários séculos, as pessoas sentem um certo fascínio pela inteligência. Várias tentativas para "mecanizá-la" foram efetuadas. Muitas tentativas precedem a idéia dos computadores digitais. É interessante notar que Ada Augusta - Condessa de Lovelace e filha de Lord Byron - nas suas anotações datando de 1842, a respeito da Máquina de Babbage, afirmou que essa máquina, se pudesse ser construída, seria capaz de processar não apenas números mas qualquer coisa que pudesse ser reduzida a um conjunto de símbolos [Rich 87].

Entretanto, foi somente por volta de 1950 que originou-se a área de Inteligência Artificial - IA - quando cientistas da Computação começaram a utilizar computadores no desenvolvimento de programas simbólicos com o objetivo de resolver problemas [DISCO 90,Miola 91].

Desde então, a área de Inteligência Artificial vem se desenvolvendo em várias linhas de pesquisa - e.g. planejamento [EWSP 91], interpretação de linguagem natural [EAIA 90] e elaboração de diagnósticos [Bachanan 85] - com o objetivo de fornecer ao computador as habilidades para efetuar funções antes desempenhadas apenas pela inteligência humana.

Uma das linhas de pesquisa em IA consiste no desenvolvimento de Sistemas Baseados em Conhecimento. Esses sistemas, de uma maneira genérica, empregam o conhecimento bumano para solucionar problemas que essencialmente necessitam do uso da inteligência bumana, ou seja, simulam a capacidade humana de raciocínio. 
Neste trabalho é desenvolvida uma aplicação composta de um Sistema Baseado em Conhecimento e um Sistema de Base de Dados. O Sistema de Base de Dados é responsável por fornecer a maior parte dos dados necessários para o Sistema Baseado em Conhecimento guiar seus mecanismos de inferência. Esses dois sistemas interagem entre si formando uma única aplicação, denominada $\mathcal{O R I O N}$ (leia-se Órion). 0 objetivo desse sistema é auxiliar usuários da área médica no processo de alocação de rins a serem transplantados em pacientes com problemas renais.

\subsection{Motivação do Trabalho}

Todo ser vivo é composto por pequenas estruturas com vida autônoma - as células. Existem muitos animais e vegetais constituídos por uma única célula. Esses seres vivos realizam digestão, respiram, possuem circulação, excreção, crescem, etc. Percebe-se que esses seres possuem todas as funções vitais, o que mostra a grande complexidade, de informação e "conhecimento", contida numa única célula.

Nos seres multicelulares - entre os quais a raça humana está situada - ocorre uma divisão de trabalho. Várias células semelhantes se reúnem para realizar uma determinda função, formando um tecido. As células nervosas, por exemplo, interligam-se com a finalidade de transmitir estímulos da periferia do organismo para o encéfalo e vice-versa. Os tecidos reúnem-se e formam os órgãos, tais como o fígado, o estômago, o coração e os rins.

Nos seres humanos, os rins situam-se na região lombar, tendo a forma de um feijão com aproximadamente 10 a $12,5 \mathrm{~cm}$ de comprimento por 5 a $7,5 \mathrm{~cm}$ de largura. $O$ peso de cada rim em uma pessoa adulta é de cerca de $125 \mathrm{~g}$. A função dos rins é a de filtrar o sangue sob pressão, eliminando impurezas através da urina.

Quando um ser humano não possui esses órgãos, ou quando eles não funcionam adequadamente, as impurezas do sangue devem ser retiradas de outras formas. Uma dessas formas é a hemodiálise.

A hemodiálise ${ }^{1}$ é um processo que consiste em conectar a pessoa a um aparelho para o qual seu sangue é bombeado, purificado e devolvido ao organismo. Esse processo é contínuo e gradual de forma que a pessoa consiga manter suas atividades vitais. Ele deve ser repetido sempre que a taxa de impurezas no sangue for grande. Em média, a hemodiálise deve ser efetuada três vezes por semana.

\footnotetext{
${ }^{1}$ hemo-: do grego haíma = sangue; -diaalise: do grego dialysis = dissolução.
} 
Outra forma de remover as impurezas do sangue é proporcionar, ao indivíduo com problemas renais, um órgão que possa executar suas funções, através do transplante renal. $\mathrm{O}$ transplante de rins consiste em substituir, ou repor, esses órgãos do corpo humano por outro retirado de um ser vivo, ou de um cadáver, através de cirurgia. Com o subsequeente funcionamento do rim transplantado, as impurezas são eliminadas pelo próprio organismo.

Não é difícil imaginar as dificuldades das pessoas que não possuem seus rins ou cujos rins não funcionam adequadamente. Todas essas pessoas têm que passar algumas horas por semana ligadas a um aparelho de hemodiálise do qual dependem suas vidas.

Entretanto, em nosso país, como em outras partes do globo, as pessoas têm um certo receio em permitir que seus órgãos sejam doados após a sua morte. Nos Estados Unidos, por exemplo, cerca de $94 \%$ das pessoas já ouviram algo a respeito de transplantes e aproximadamente $70 \%$ receberam alguma informação sobre a doação de órgãos; todavia, apenas $19 \%$ registraram-se como doadores [Manninen 85].

Somando-se a esse aspecto, de acordo com a legislação federal, todo brasileiro não é um doador de órgãos a não ser que seja explicitamente declarado o contrário. Em outros países, dentre eles a França, ocorre justamente o oposto. Esses e outros aspectos contribuem de forma significativa para que o número de órgãos disponiveis para transplante em nosso país seja muito pequeno.

Desse modo, as pessoas que aguardam por um rim têm que esperar anos até receber um transplante. Muitas sequer chegam a ter tempo para isso... outras podem rejeitar o órgão algum tempo após o transplante. Além das consequêencias fisiológicas de uma rejeição, há também consequiências psicológicas que marcam profundamente a vida dessas pessoas.

Foi justamente para promover e desenvolver o transplante renal, com órgãos provenientes de cadáveres, que foi criado em nosso estado o sistema São Paulo Interior Transplante - SPIT - cuja Coordenadoria Central se localiza no Hospital das Clínicas da Faculdade de Medicina de Ribeirão Preto - USP - HCFMRP. Esse sistema engloba vários hospitais do estado de São Paulo com o intuito de formar um "banco de receptores", ou seja, um conjunto de pessoas que necessitam realizar transplante de rins. Um dos objetivos primários do SPIT é alocar os rins disponíveis aos receptores de modo a aumentar as chances de sucesso no transplante [Halasz 91]. 
Com o objetivo de automatizar e tornar homogêneo o processo de alocação de órgãos aos receptores, o sistema São Paulo Interior Transplante desenvolveu um sistema computadorizado, denominado TX3. Além do auxilio no processo de alocação, esse sistema é também responsável por cadastrar os receptores, gerar relatórios, etc. Como o sistema TX3 é basicamente composto por um Sistema de Base de Dados, seu auxílio aos especialistas no processo de decisão é incompleto quando é necessário raciocinar sobre os dados disponiveis.

Com o passar do tempo, os especialistas sentiram a necessidade de considerar outros aspectos no processo de alocação que não foram considerados na fase de desenvolvimento do sistema TX3. Alguns desses novos aspectos não poderiam ser considerados num programa apenas composto por um Sistema de Base de Dados, o qual não manipula conhecimento ou informações incompletas.

Diante disso, pensou-se em desenvolver, neste trabalho, o sistema $\mathcal{O R I O N}^{2}$, que incorpora e amplia as funções do sistema TX3. A ampliação das funçōes em $\mathcal{O} R I O \mathcal{N}$ tem como metas fornecer uma visão ampla aos especialistas do processo de alocação de órgãos e permitir explicar as decisóes por ele tomadas. $\mathcal{O R I O N}$, é conveniente salientar, foi desenvolvido independentemente do sistema TX3 existente, contudo obedecendo aos critérios determinados pelo sistema São Paulo Interior Transplante.

Devido à natureza dinâmica da área de transplantes - onde os especialistas estão sempre pesquisando melhores formas de selecionar os receptores mais promissores para um determinado órgão e minimizando as chances de rejeição - outro aspecto positivo do sistema desenvolvido é permitir que as regras de conhecimento possam ser trocadas convenientemente para que possam refletir essas novas situações provenientes de pesquisas mais recentes.

Como um Sistema de Base de Dados não consegue "raciocinar", a aplicação desenvolvida é composta pela interação de um Sistema Baseado em Conhecimento e um Sistema de Base de Dados convencional. Dessa forma, utiliza-se as facilidades de gerenciamento de dados fornecidas por um Sistema de Base de Dados e a capacidade de raciocínio de um Sistema Baseado em Conhecimento. Para a construção das Bases de Conhecimento e Dados, foi utilizado o "conhecimento" contido no sistema SPIT.

\footnotetext{
${ }^{2}$ Esse nome não constitui uma composição de siglas. A priori, ele foi escolhido pelo efeito sonoro produzido ao ser pronunciado. Só mais tarde é que verificou-se que Órion significa Caçador [Sagan 85]. Coincidência ou não, o sistema ORION procura, busca ou caça os receptores mais promissores para um determindado rim.
} 


\subsection{Organização do Trabalho}

Este trabalho está organizado da seguinte forma:

No Capitulo 2 é efetuada uma revisão bibliográfica dos Sistemas de Base de Dados e Sistemas Baseados em Conhecimento, descrevendo algumas das suas respectivas características. É explicado o motivo do uso do termo Sistema de Base de Dados como substituto de Sistema de Informação. São mostrados, também, alguns exemplos de cada um dos sistemas. Por último, é realizado um estudo comparativo entre Bases de Dados e Bases de Conhecimento, salientando suas diferenças.

No Capítulo 3 são mostradas as razões pelas quais é considerada, neste trabalho, a interação entre Sistemas de Bases de Dados e Sistemas Baseados em Conhecimento. A seguir, são descritas diversas formas pelas quais essa interação pode ser efetuada. São apresentadas basicamente três classes de interações entre esses sistemas.

No Capítulo 4 é apresentada a composição do sistema São Paulo Interior Transplante, ressaltando aspectos gerais de seu funcionamento. São mostradas as funções desempenhadas por cada um dos seus hospitais componentes bem como a atuação dos pacientes que aguardam um transplante renal.

Uma descrição dos fatores considerados - pelo sistema SPIT - no processo de alocação de órgãos é fornecida no Capítulo 5. Esses fatores são agrupados de acordo com o grau de influência que exercem na qualidade e na sobrevida do receptor transplantado.

As regras de conhecimento, utilizadas pelo Sistema Baseado em Conhecimento no processo de alocação de órgãos aos receptores, são descritas no Capítulo 6. Também é mostrado como as essas regras foram transcritas para a linguagem de implementação do Sistema Baseado em Conhecimento.

A idéia geral de funcionamento do sistema $\mathcal{O R I O N}$ é descrita no Capitulo 7, destacando a forma de interação - dentre aquelas citadas no Capítulo 2 - entre o Sistema de Base de Dados e o Sistema Baseado em Conhecimento.

No Capítulo 8 são apresentados alguns exemplos de utilização da aplicação ORION. Os exemplos são descritos de forma separada para cada subsistema compondo a aplicação desenvolvida.

As conclusões deste trabalho encontram-se no Capítulo 9. Também são apresentadas propostas para trabalhos futuros. 
No Apêndice A são descritas as siglas e abreviaturas mais utilizadas.

Finalmente, no Apêndice B é detalhado o projeto do Sistema de Base de Dados do sistema $\mathcal{O} \mathcal{I O N}$, através do método Jackson System Design. Uma visão geral desse método também é fornecida. 


\section{Capítulo 2}

\section{Sistemas de Base de Dados e Sistemas Baseados em Conhecimento}

\subsection{Considerações Iniciais}

Neste capítulo é efetuada uma revisão bibliográfica sobre Sistemas de Base de Dados e Sistemas Baseados em Conhecimento, mostrando suas características básicas. Exemplos de cada um desses sistemas são expostos. São salientadas as diferenças entre Sistemas Baseados em Conhecimento e Sistemas Especialistas e, por último, são descritos alguns diferenciadores entre Bases de Dados e Bases de Conhecimento.

Nas seções seguintes, bem como no restante deste trabalho, o termo Base de Dados refere-se a uma base de dados convencional.

\subsection{Sistemas de Base de Dados}

Originalmente, os dados de cada programa eram manipulados individualmente pela própria aplicação - Figura 2.1. Esse individualismo, embora parecesse simples, acarretou duplicações muito grandes de esforço e de informação. Adicionalmente, as diversas aplicações não conseguiam compartilhar seus dados de forma trivial. 

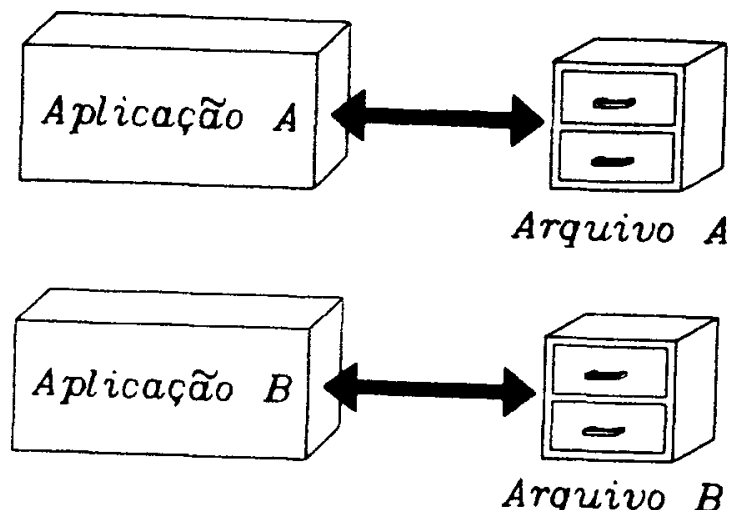

Arquivo $B$

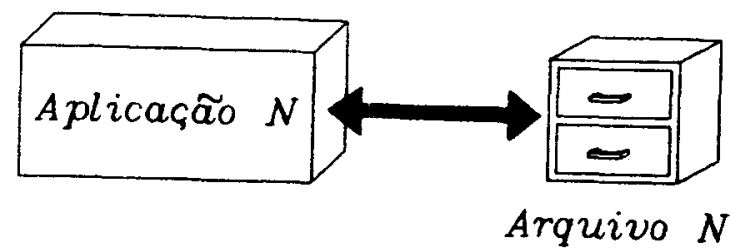

Figura 2.1: Dependência entre Aplicação e Arquivo

Para tentar minimizar esses problemas, os Sistemas Gerenciadores de Arquivos, ou simplesmente Sistemas de Arquivos, foram introduzidos. Os objetivos desses sistemas eram:

- Facilitar a alocação de dados nos dispositivos físicos e

- Permitir uma forma de compartilhar os dados entre as diversas aplicações.

Com isso, criou-se uma padronização nos métodos de acesso aos dados utilizados pelas aplicações [Davis 90], como mostra a Figura 2.2. Um certo grau de independência do armazenamento físico foi obtido, uma vez que as modificações na estrutura física, ou na tecnologia do meio de armazenamento, poderiam ser incorporadas nos métodos comuns de acesso sem afetar as aplicações. Compartilhar os dados tornou-se mais fácil e as duplicações das informações diminuiram.

Entretanto, todos os métodos ainda se fundamentavam nas propriedades da alocação física dos dados. 0 usuário tinha que estar ciente de alguns dos detalhes de como os dados estavam armazenados e como podiam ser recuperados. Usualmente, os programas aplicativos faziam certas suposiçóes a respeito dessas propriedades físicas dos dados, tais como características do volume, formato do registro e tamanho do arquivo. 


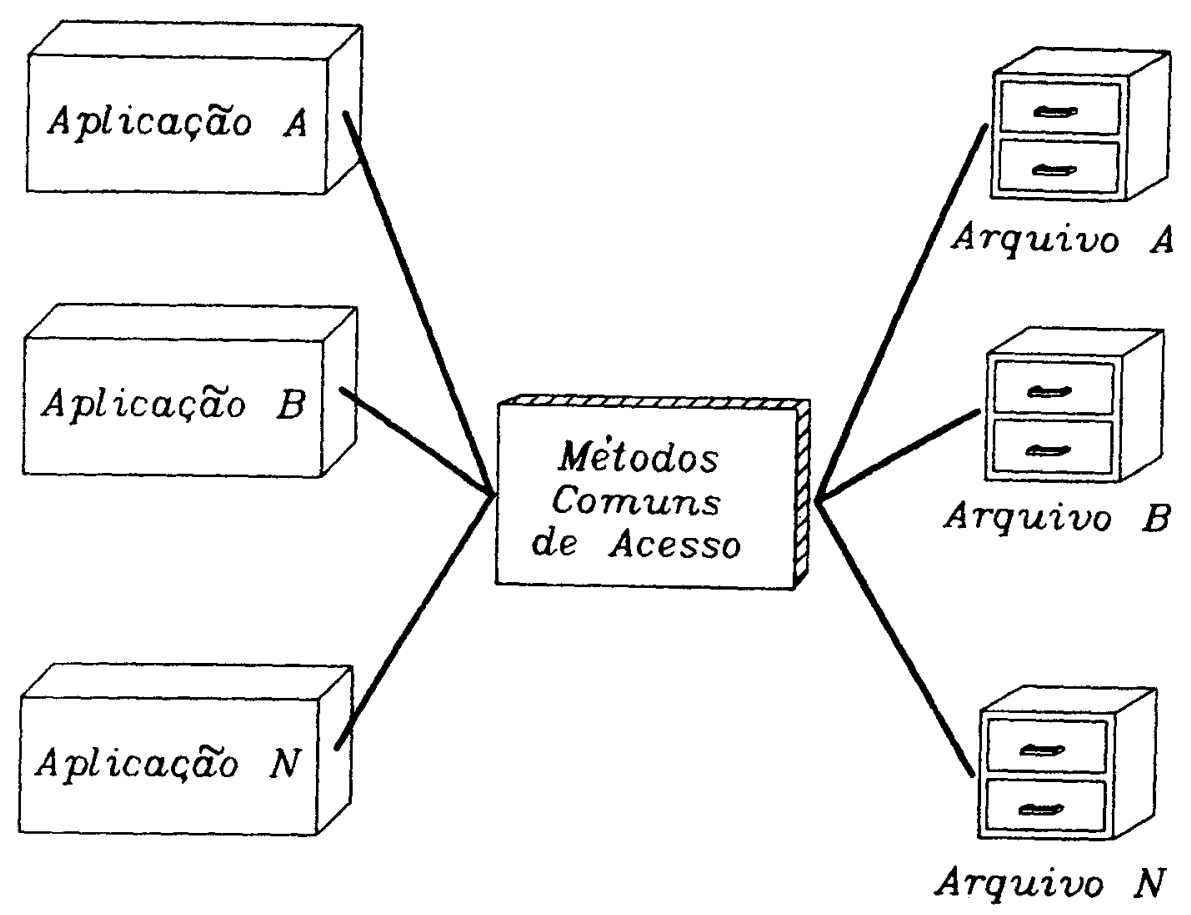

Figura 2.2: Sistema Gerenciador de Arquivos

Essa situação tornou possivel o acesso às informações apenas para um usuário sofisticado. E mais ainda: os programas eram muito dependentes da organização física dos dados. Eles deveriam ser reescritos sempre que os arquivos fossem reorganizados. Programas diferentes necessitavam de diferentes arquivos, mesmo se eles manipulassem, essencialmente, os mesmos dados, pois os programas requeriam que esses dados estivessem organizados de formas distintas.

Com o advento, em meados dos anos 60, dos Sistemas Gerenciadores de Bases de Dados - SGBD - generalizados, a organização e o acesso às informações tornaram-se mais fáceis. Os SGBDs servem como uma interface entre o usuário e as cópias físicas dos dados, como expõe a Figura 2.3. 0 usuário especifica quais dados ele deseja e de que forma; ele não necessita especificar onde eles se localizam ou como obtềlos.

Dessa forma, um Sistema Gerenciador de Base de Dados age como um intermediário entre uma aplicação e a estrutura física de armazenamento, denominada Base de Dados - BD. Pode-se definir um Sistema Gerenciador de Base de Dados como um conjunto de procedimentos e estruturas de dados que isolam a aplicação dos detalhes de criação, armazenamento, recuperação e modificação das Bases de Dados, permitindo que a informação seja compartilhada entre diversas aplicações [Date 86]. 


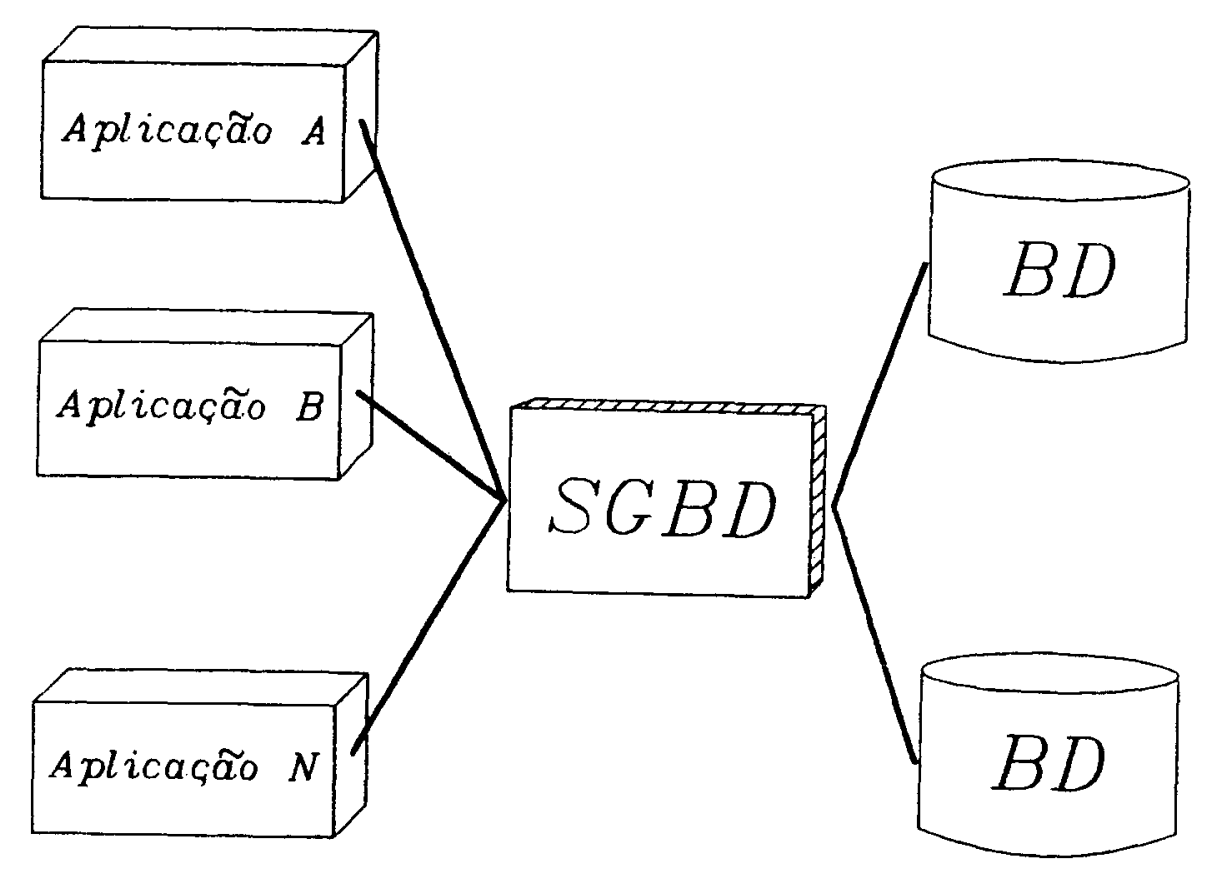

Figura 2.3: Sistema Gerenciador de Base de Dados

Além de fornecer essa independência da organização física entre aplicações e dados, o SGBD é responsável pela integridade, segurança e controle de acesso concorrente aos dados. Também deve ser confiável - considerando as falhas de hardware como as de software - e eficiente no tempo de pesquisa e no espaço utilizado para o armazenamento da informação [Ullman 82].

Sem dúvida alguma, a tecnologia de gerenciamento de dados progrediu rapidamente nos últimos anos [CA 90,Wiederhold 84]. Atualmente existem muitos Sistemas Gerenciadores de Bases de Dados disponíveis comercialmente. Esses sistemas utilizam diversos modelos de dados - padrões conforme os quais os dados são organizados - entre eles o hierárquico, o de rede ou o relacional [Martin 86], para armazenar e recuperar grandes quantidades de informação em vários meios físicos, incluindo microcomputadores, estações de trabalho, até máquinas especializadas em gerenciamento de Base de Dados [Hikita 85,Leland 85,Scholl 87].

Neste trabalho, um Sistema de Base de Dados - SBD - é definido como:

$$
\mathrm{SBD}=\mathrm{SGBD}+\mathrm{BD}+\text { Interface com o Usuário }
$$

Um forma esquemática pode ser vista na Figura 2.4. A Interface é responsável pela comunicação entre o SGBD e o usuário, possibilitando a troca de informação entre eles. 


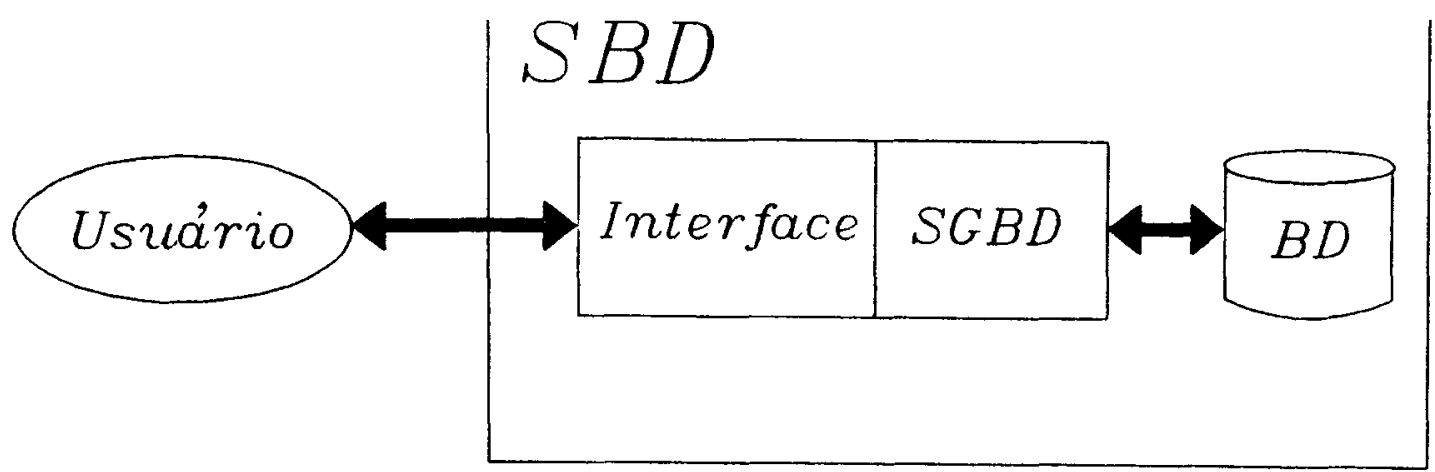

Figura 2.4: Sistema de Base de Dados

É conveniente salientar que o termo Sistema de Base de Dados poderia ser entendido como Sistema de Informação. Entretanto, no entender desta dissertação, um Sistema de Informação é constituído por:

- aplicaçōes que utilizam um SGBD e

- aplicações que não utilizam um SGBD.

Como os Sistemas de Base de Dados constituem uma subclasse dos Sistemas de Informação, aqui, como em grande parte das referências consultadas, evitou-se tal equivalência.

Na Tabela 2.1 são citados alguns Sistemas Gerenciadores de Base de Dados existentes. IDS, o primeiro SGBD generalizado, foi utilizado pela empresa General Eletric - GE - inicialmente em 1.961 numa aplicação de manufaturação; sua distribuição em grande escala, entretanto, ocorreu somente em 1.964. 


\begin{tabular}{|l|l|c|}
\hline \multicolumn{1}{|c|}{ Sistema } & \multicolumn{1}{|c|}{ Desenvolvedor } & Lançamento \\
\hline \hline IDS & GE & 1964 \\
\hline IMS & IBM & 1968 \\
\hline ADABAS & Software AG & 1974 \\
\hline Ingres & Ingres Corp. & 1981 \\
\hline SQL/DS & IBM & 1981 \\
\hline ZIM & Sterling Software Int. & 1983 \\
\hline Sybase & Sybase, Inc. & 1987 \\
\hline
\end{tabular}

$O$ ano de lançamento de cada produto foi obtido através de: IDS, IMS, ADABAS, SQL/DS [Wiederhold 84]; Ingres, Sybase [Thomas 90]; ZIM, informe técnico distribuido pela RCM Informática Ltda.

Tabela 2.1: Alguns Sistemas Gerenciadores de Base de Dados

\subsection{Sistemas Baseados em Conhecimento}

Sistemas Baseados em Conhecimento - SBCs - de uma maneira genérica são programas, executados por computador, que empregam o conhecimento humano para resolver problemas que essencialmente necessitam do uso da inteligência humana para serem solucionados. Assim sendo, os SBCs tentam simular a capacidade humana de raciocinar simbolicamente na resolução de problemas [Ford 87].

Todavia, o que diferencia SBCs dos sistemas convencionais não reside simplesmente no fato que SBCs possuem conhecimento e raciocinam. Todos os programas possuem, de certa forma, esses elementos; caso contrário eles não poderiam realizar as tarefas que realizam.

Os Sistemas Baseados em Conhecimento diferem na sua organização, na forma de incorporar o conhecimento, no método de execução que empregam e no impacto que causam nos usuários com os quais interagem. Nos Sistemas Baseados em Conhecimento há um interesse para tornar explícito o conhecimento contido num programa. Tornar o conhecimento explícito não se restringe meramente a um princípio de organização mas sim na distinção entre dois tipos de conhecimento. Conhecimento pode ser incluído num programa como:

- um procedimento ou

- uma estrutura de dados - e, logicamente, o código necessário para interpretar a estrutura de dados. 


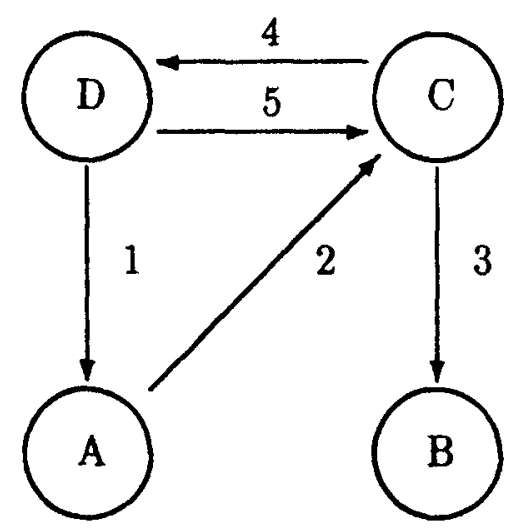

Figura 2.5: Sistema de Transição de Estados

Essa distinção corresponde a uma diferença filosófica entre saber como fazer e o que fazer.

Um exemplo pode ajudar a esclarecer esse ponto. Considere o sistema de transição de estados mostrado na Figura 2.5. A versão procedimental desse sistema, dada a seguir, possui informaçôes de como simular a transição de estados.
A: se entrada $=2$ enţ̌o desvie para estado $C$
B : $\quad$ im
$C$ : se entrada $=4$ então desvie para estado $D$
se entrada $=3$ então desvie para estado $B$
$D$ : se entrada $=5$ então desvie para estado $C$
se entrada $=1$ então desvie para estado $A$

Caso as informações sobre esse sistema sejam colocadas numa estrutura de dados, por exemplo uma matriz,

\begin{tabular}{|c||c|c|c|c|}
\hline Transição & A & B & C & D \\
\hline \hline A & & & 2 & \\
\hline B & & & & \\
\hline C & & 3 & & 4 \\
\hline D & 1 & & 5 & \\
\hline
\end{tabular}


e um algoritmo genérico seja construído para manipular a matriz, por exemplo,

Seja $W$ a matriz de transição do exemplo. Estando o sistema no estado $i$ e ocorrendo a entrada $W_{i j}$, o sistema deverá ir para o estado $j$ e repetir esse processo. Esse processo termina quando todas as entradas de $W$ para o estado atual $i$ estiverem vazias.

essa versão interpretada além de saber como fazer, sabe o que as transiçôes de estado significam. Isto permite que essa versão manipule outro sistema análogo ao exemplo fornecido, bastando para isto alterar as entradas da matriz. Nesse caso, o conhecimento sobre o sistema é mais explícito.

O desenvolvimento de Sistemas Baseados em Conhecimento está intimamente ligado a situações que não admitem soluções ótimas ou quando o tempo computacional necessário para encontrar-se uma solução ótima é inconcebivel em situações práticas. Nesse caso os SBCs, como os seres humanos, combinam modelos e regras heuristicas para solucionar o problema.

Muitos profissionais realizam tarefas que requerem um julgamento hábil e positivo. Muitas vezes, esses requisitos originam-se da complexidade, ambigüidade ou incerteza dos dados e métodos de solução disponíveis. Dessa forma, dependendo da aplicação, os Sistemas Baseados em Conhecimento devem ser capazes de trabalhar com informação e conhecimento imprecisos [Lecot 86, $\mathrm{Ng} 90$, Richards 88, Zadeh 83].

Como durante as diversas fases de construção dos Sistemas Baseados em Conhecimento [Debenham 89,Hayes-Roth 84], é fornecida a eles a capacidade de explicar e justificar os resultados obtidos de uma forma "amigável" aos seres humanos [Swartout 91], os SBCs têm ganho interesse de uma grande variedade de usuários.

A forma de interação entre os SBCs com os usuários - oferecendo formas de explicar como chegaram a determinadas conclusões - muitas vezes causa nesses individuos uma impressão de raciocínio, ou seja, de inteligência. As explicaçōes são possíveis pela transformação de afirmativas e regras heurísticas em linhas de raciocínio [Thompson 85]. Cada linha de raciocínio parte de um conjunto de hipóteses e, pela aplicação de regras heurísticas, mostra como foi possível chegar a uma determinada conclusão. 


\subsubsection{Sistemas Especialistas}

Das várias tarefas realizadas pela mente humana, uma grande variedade exige muito conhecimento especializado para ser desempenhada. Normalmente, essas tarefas - nas quais encontram-se a diagnose médica [Rennels 87] e a análise científica [Hohne 87] - são realizadas por especialistas humanos que acumularam o alto grau de conhecimento necessário.

A existência de programas de computador que realizam essas tarefas complexas é importante, pois, em algumas áreas, o número de especialistas é muito reduzido. Tais programas são denominados Sistemas Especialistas - SEs.

Como o conhecimento necessário no desenvolvimento de SEs é muito grande e complexo [Stefik 82], esses sistemas constituem uma classe mais restrita dos Sistemas Baseados em Conhecimento, como pode ser observado na Figura 2.6. Pode-se dizer que um Sistema Especialista é um SBC capaz de resolver problemas que, quando solucionados por especialistas humanos, requerem conhecimento profundo e alto nivel de habilidade [Waterman 86].

Neste trabalho, o uso do termo Sistema Especialista como sinônimo de Sistema Baseado em Conhecimento é evitado. Em grande parte da literatura, entretanto, esses termos são utilizados indistintamente.

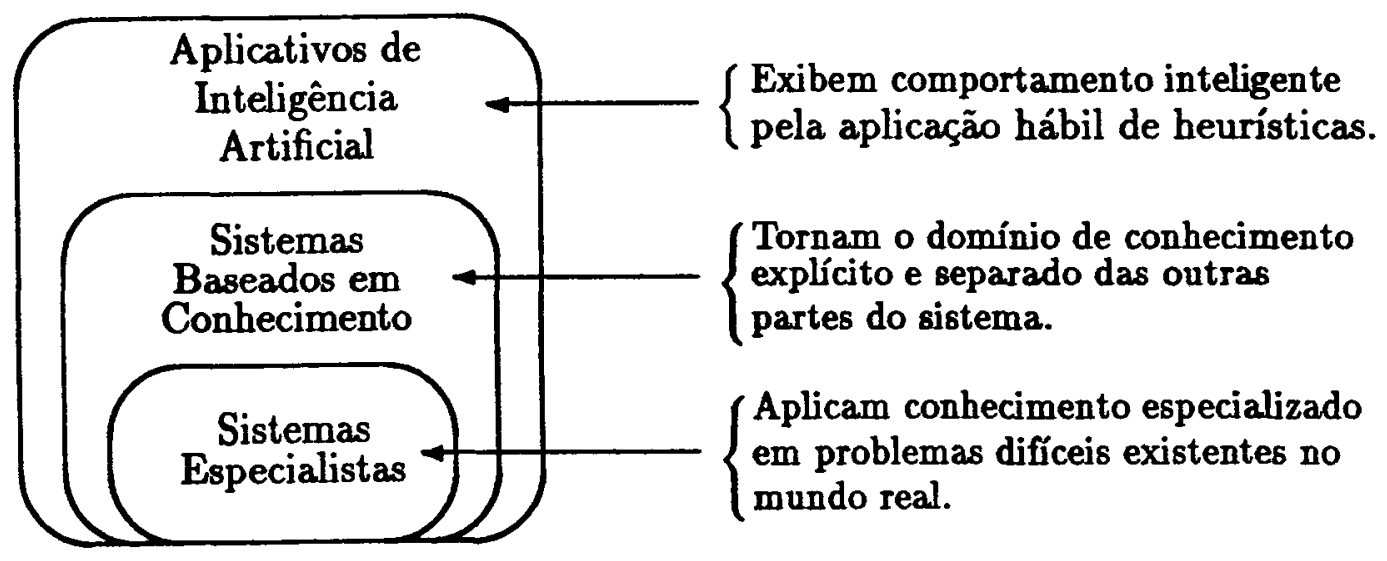

Figura 2.6: $I A, S B C s$ e $S E s$ 


\subsubsection{Componentes Básicos}

De acordo com [Rodrigues 89], um SBC, mostrado na Figura 2.7, é composto pelos seguintes elementos básicos:

- Base de Conhecimento;

- Área de Trabalho;

- Motor de Inferência e

- Interface com o Usuário:

口 Módulo Coletor de Dados e

口 Módulo de Explicação.

A Base de Conhecimento - BC - contém informações, ao nível de um especialista, necessárias para solucionar problemas num domínio específico. Essas informações são representadas de diversas formas, mas principalmente como um conjunto de regras de produção [Hayes-Roth 87]. Outros esquemas de representação incluem frames, redes semânticas e scripts [Ávila 91,Ávila 92,Rich 88, Sawaki 91].

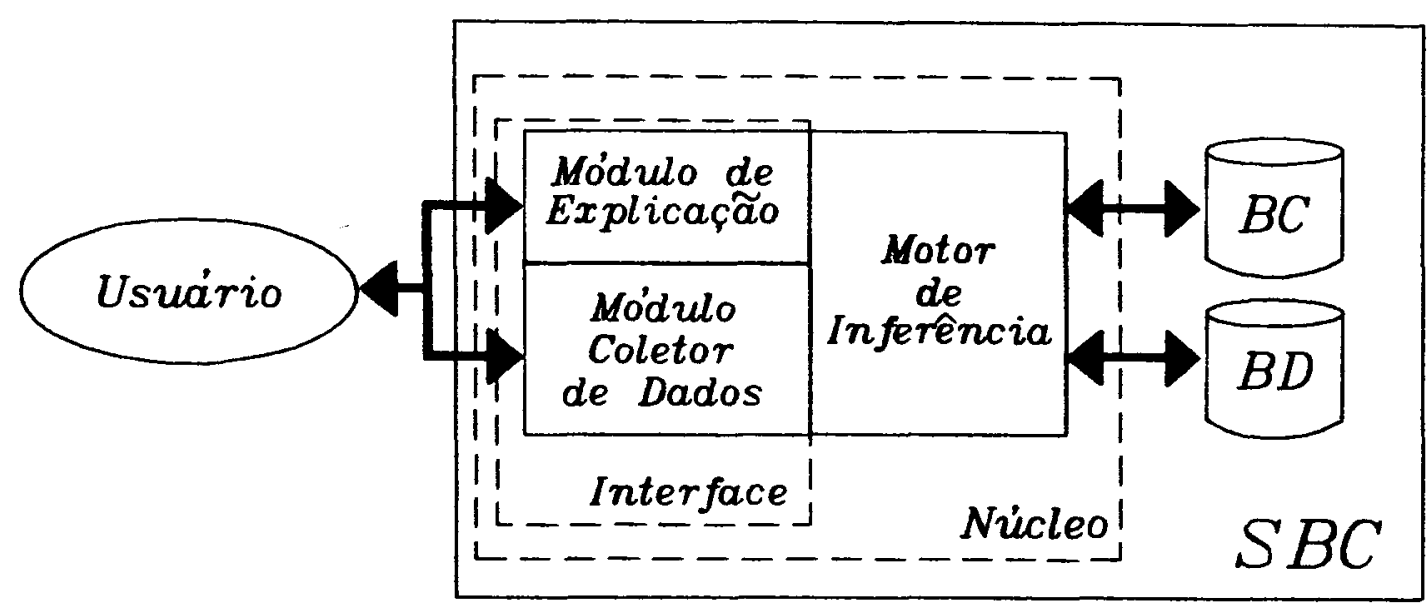

Figura 2.7: Sistema Baseado em Conhecimento 
Os fatos deduzidos a respeito do problema corrente são armazenados, pelo Motor de Inferência, numa Base de Dados - a Área de Trabalho - e atualizados sempre que novas informaçôes tornam-se disponiveis. Geralmente, o conteúdo da Área de Trabalho é descartado ao término da operação do SBC.

O Motor de Inferência é responsável em aplicar as estratégias de inferência e controle. Utilizando uma linha de raciocínio, processa as informações contidas na Base de Conhecimento e na Área de Trabalho, tentando encontrar uma solução para o problema no qual está trabalhando.

Muitas vezes, o Motor de Inferência necessita de dados específicos durante a solução de um problema. O Módulo Coletor de Dados é então ativado, interagindo com o usuário com o objetivo de perguntar e adquirir as respostas. Uma vez obtidas as respostas, elas são enviadas ao Motor de Inferência para a continuação da linha de raciocinio sendo utilizada.

São duas as estratégias de raciocínio usualmente utilizadas [Payne 90]:

- Encadeamento Regressivo ou "Backward Chaining" e

- Encadeamento Progressivo ou "Forward Chaining".

No Encadeamento Regressivo, o Motor de Inferência utiliza linhas de raciocínio que partem das metas em direção aos dados. Esta estratégia corresponde a seguinte pergunta:

É possivel provar as metas especificadas a partir das informações disponíveis?

No Encadeamento Progressivo, ocorre exatamente o oposto, podendo ser associada a seguinte pergunta:

O que é possivel concluir, ou seja, quais as metas que podem ser provadas a partir das informações disponiveis?

É função do Módulo de Explicação indicar ao usuário, sempre a pedido deste, como o Motor de Inferência chegou a uma determinada conclusão, porque realizou uma pergunta, etc.

O conjunto formado pelo Motor de Inferência, Módulo Coletor de Dados e Módulo de Explicação é denominado Núcleo do Sistema Baseado em Conhecimento. 


\begin{tabular}{|l|l|l|l|c|}
\hline Sistema & \multicolumn{1}{|c|}{$\begin{array}{c}\text { Área de } \\
\text { Aplicação }\end{array}$} & \multicolumn{1}{|c|}{ Descrição } & $\begin{array}{l}\text { Centro de } \\
\text { Pesquisa }\end{array}$ & $\begin{array}{l}\text { Lança- } \\
\text { mento }\end{array}$ \\
\hline \hline Dendral & Química & $\begin{array}{l}\text { Identificação de compostos } \\
\text { orgânicos pela análise de } \\
\text { espectrograma de massa }\end{array}$ & $\begin{array}{l}\text { Stanford } \\
\text { University }\end{array}$ & 1965 \\
\hline Mycin & Medicina & $\begin{array}{l}\text { Diagnose de doenças } \\
\text { infecciosas e recomen- } \\
\text { dação da droga } \\
\text { apropriada ao tratamento }\end{array}$ & $\begin{array}{l}\text { Stanford } \\
\text { University }\end{array}$ & 1975 \\
\hline Molgen & Biologia & $\begin{array}{l}\text { Planejamento de experi- } \\
\text { mentos em Génetica } \\
\text { Molecular }\end{array}$ & $\begin{array}{l}\text { Stanford } \\
\text { University }\end{array}$ & 1977 \\
\hline Macsyma & Matemática & Manipulação Algébrica & MIT & 1979 \\
\hline Prospector & Geologia & $\begin{array}{l}\text { Avaliação de sítios geoló- } \\
\text { gicos pela existência de } \\
\text { determinados depósitos } \\
\text { de minérios }\end{array}$ & $\begin{array}{l}\text { SRI } \\
\text { International }\end{array}$ & 1979 \\
\hline Gamma & Ciência & $\begin{array}{l}\text { Interpretação de espectros } \\
\text { de ativação de Rajos } \gamma\end{array}$ & $\begin{array}{l}\text { Yale } \\
\text { University }\end{array}$ & 1979 \\
\hline Crib & $\begin{array}{l}\text { Diagnose } \\
\text { de Falha }\end{array}$ & $\begin{array}{l}\text { Diagnose de falhas em } \\
\text { software e hardware }\end{array}$ & $\begin{array}{l}\text { International } \\
\text { Computers }\end{array}$ & 1980 \\
\hline
\end{tabular}

Tabela 2.2: Alguns Sistemas Especialistas

Na Tabela 2.2 [Bramer 82], uma exposição de alguns Sistemas Especialistas existentes é fornecida com o objetivo de mostrar algumas áreas onde eles são utilizados [Alty 84,Klahr 86,Nau 83]. Dendral, datando de 1965, foi o primeiro SE e o que obteve maior sucesso na sua época.

\subsection{Bases de Conhecimento versus Bases de Da- dos}

Bases de Conhecimento podem não parecer diferentes de Bases de Dados. Ambas são estruturas de dados, ou conjuntos de estruturas de dados, nas quais a informação é armazenada e recuperada. Ainda que intuitivamente pareçam semelhantes, Bases de Conhecimento e Bases de Dados não representam a mesma coisa. Segundo [Freundlich 90], existem quatro propostas para distinguir uma BD de uma BC, resumidas na Tabela 2.3. $O$ autor salienta que esses diferenciadores devem ser considerados como um todo e não separadamente. 


\begin{tabular}{|l||l|l|}
\hline \multicolumn{1}{|c||}{ Diferenciador } & \multicolumn{1}{c|}{ Base de Dados } & Base de Conhecimento \\
\hline \hline Coletor & Escriturário & Especialista \\
\hline Uso & Recuperação & Múltiplo \\
\hline Tipo de Informação & Fatos & Alto Nível \\
\hline Requisitos Teóricos & Teoria da Computação & Interpretação \\
\hline
\end{tabular}

Tabela 2.3: Propostas para a Distinção entre uma $B D$ e uma $B C$

Conforme o primeiro diferenciador, quando um especialista - alguém com conhecimento especializado em algum domínio específico - é necessário para coletar a informação, aquela informação é conhecimento e é armazenada numa Base de Conhecimento; contudo, quando um escriturário pode fazê-lo - conhecimento especializado não é realmente necessário - a informação é um dado e é armazenada numa Base de Dados.

O segundo diferenciador indica que Bases de Dados são usadas apenas para recuperar informação, enquanto Bases de Conhecimento possuem muitos usos: informar, diagnosticar, monitorar e assim por diante.

O terceiro diferenciador é baseado no tipo de informação armazenada: fatos, tais como uma descrição de uma conta bancária, são dados; abstrações de níveis mais elevados - por exemplo, uma afirmação que baleias são animais - é conhecimento.

De acordo com o quarto diferenciador, as bases possuem requisitos teóricos diferentes. Uma Base de Conhecimento possui uma interpretação, ou seja, uma especificação de seu relacionamento com o mundo real. Por outro lado, uma Base de Dados é guarnecida com uma teoria computacional de forma que possa gerenciar o armazenamento físico das informações.

De certo modo, as Bases de Dados possuem uma semântica mas é o usuário ou analista que realiza essa interpretação. Por exemplo, interpreta-se um registro de empregado na Base de Dados como uma referência a um empregado.

Com isso, é possível concluir que [Brachman 88]:

- A complexidade das informações armazenadas numa Base de Conhecimento é muito maior daquela suportada por uma BD.

a Como já descrito na página 1, Sistemas Baseados em Conhecimento são programas que tentam simular a capacidade de raciocínio do ser 
humano. Por isso, usualmente esses sistemas têm que lidar com informaçôes incompletas. Os Sistemas de Base de Dados não possuem nenhum mecanismo para deixar alguns dos campos da Base de Dados sem alguma informação [Grahne 91]. Cada campo deve ser preenchido com um valor individual. Quando expressões quantificadas são permitidas numa Base de Dados, elas servem apenas como condições de integridade [Menezes Filho 88] - para a verificação da Base de Dados - e não como fatos armazenados, disponiveis para recuperação e inferência.

- Os fatos armazenados numa Base de Dados devem amoldar-se a uma forma rígida e exceções não são permitidas. Por outro lado, BCs usualmente abrangem uma vasta área de conhecimento não homogêneo.

- As Bases de Conhecimento dependem crucialmente de uma interpretação das estruturas de conhecimento. As Bases de Dados, por outro lado, explicitamente evitam o interesse com o que os dados significam ou quaisquer conseqüências lógicas que eles possam ter. Os SBDs estão comumente interessados em registros, que são meramente estruturas de dados sem interpretação. Uma consequêencia importante dessa diferença é que não há uma noção de vínculo - e assim de inferência a respeito do domínio - definido pelas Bases de Dados. Enquanto BDs podem permitir que questões complexas sejam respondidas, os cálculos efetuados são apenas a respeito das estruturas de dados - contando campos, procura por sequêencia de caracteres, etc.

- As BCs representam descrições genéricas de maneira a permitir que novas classes ou instâncias sejam reconhecidas ou classificadas sob elas. Bases de Dados são apenas representações planas dos fatos e não têm condições para reconhecer novos itens como membros de classes para as quais eles não foram explicitamente declarados a pertencer ${ }^{1}$.

- Aplicações típicas de Inteligência Artificial possuem mais classes (relações) do que instâncias, ao passo que Bases de Dados são dirigidas para problemas onde as instâncias são armazenadas em número muito maior que as relações.

Essas diferenças entre Bases de Conhecimento e Bases de Dados não são, de modo algum, algo rígido. É ainda possível considerar uma Base de Dados relacional como uma Base de Conhecimento extremamente simples [Braga 88]. Todavia, dadas as complexidades e necessidades das aplicações em Inteligência Artificial,

\footnotetext{
${ }^{1}$ Isso tornou-se possivel somente com o advento das Bases de Dados Orientadas a Objeto [Unland 90].
} 
isto não aparenta ser uma visão produtiva. Gerenciamento de Bases de Dados está ligado principalmente com tarefas de segurança, compartilhamento e distribuição. Ele está muito menos interessado com as formas de conhecimento que podem ser armazenadas e suas conseqüências lógicas. Já o trabalho com Bases de Conhecimento está centralizado principalmente na interpretação e inferência.

\subsection{Considerações Finais}

Sem dúvida nenhuma, Bases de Dados e Bases de Conhecimento armazenam informaçào de algum tipo. As diferenças residem nas formas segundo as quais a informação é coletada, utilizada, abstraída e embasada teoricamente.

Outro ponto importante é que Sistemas Especialistas constituem um subconjunto de Sistemas Baseados em Conhecimento. Nos SEs, os níveis de habilidade são muito profundos em um domínio restrito de conhecimento.

Deve ser ressaltado também que um Sistema de Base de Dados constitui uma classe mais restrita dos Sistemas de Informação. Nos SBDs, os programas utilizam um Sistema Gerenciador de Base de Dados para manipular suas informaçōes; num Sistema de Informação, entretando, os programas podem ou não utilizarem-se de um SGBD.

Salientadas algumas características dos Sistemas de Bases de Dados e dos Sistemas Baseados em Conhecimento, no próximo capítulo são descritas diversas formas de interação entre esses sistemas, mostrando os benefícios obtidos em relação à utilização separada de cada um deles. 


\section{Capítulo 3}

\section{Interações entre Sistemas de Base de Dados e Sistemas Baseados em Conhecimento}

\subsection{Considerações Iniciais}

Há diversas formas pelas quais um Sistema Baseado em Conhecimento pode obter os dados necessários para dirigir seus mecanismos de inferência. Muitos SBCs simplesmente obtêm todos os seus dados diretamente dos usuários à medida que estes interagem com o sistema. Outros coletam seus dados de sensores de tempo real. Existem ainda aqueles que utilizam dados existentes num dispositivo secundário de armazenamento.

Cada vez mais, os Sistemas Baseados em Conhecimento estão tornando-se progressivamente complexos e diversos [Mattos 90a]. A necessidade de gerenciamento eficiente de dados para suas BCs - cada vez maiores - é aparente, pois com a utilização de Sistemas de Base de Dados, alguns dos dados fatuais operacionais requeridos pelo $\mathrm{SBC}$ estão, freqüentemente, disponiveis numa Base de Dados. Torna-se necessária, portanto, apenas uma interação apropriada entre o SBD e o SBC [Mattos 90b].

Neste capítulo são apresentadas diversas formas através das quais um SBC pode interagir com um SBD. É conveniente ressaltar que neste trabalho é desenvolvido o sistema $\mathcal{O} \mathcal{} \mathcal{} \mathcal{N}$ composto por um SBC e um SBD que interagem entre si. 


\subsection{Formas de Interação entre SBCs e SBDs}

Há uma variedade de formas pelas quais um Sistema Baseado em Conhecimento pode interagir com um Sistema de Base de Dados de maneira a obter os dados necessários para sua execução. Tipicamente, é possível dividir estes tipos de interação em três classes [Zobaidie 87]:

- SBD Inteligente;

- SBC Melhorado e

- Comunicação Intersistemas.

\subsubsection{SBD Inteligente}

Nesta classe de sistemas, um componente de inferência é embutido no próprio Sistema de Base de Dados resultando numa Base de Dados "inteligenten. O objetivo desse componente é melhorar a eficiência e funcionalidade do SBD. 0 aumento da eficiência pode ser obtido através da otimização das perguntas que são passadas para o SBD. Outra possibilidade consiste na extração de informações que não estão explicitamente armazenadas mas que podem ser obtidas através de inferências sobre os fatos contidos na Base de Dados e regras armazenadas na Base de Conhecimento.

Praticamente, há três métodos pelos quais esse componente de inferência pode ser incorporado ao Sistema de Base de Dados:

- Método Integrado;

- Método de Filtragem Dedutiva e

- Método Interativo.

No Método Integrado - Figura 3.1 - os procedimentos de inferência são embutidos como uma parte integral do SBD [Harris 87]. No segundo método, como pode ser visto na Figura 3.2, as perguntas do usuário são filtradas através do componente de inferência antes de serem processadas pelo Sistema de Base de Dados, embora de forma transparente ao usuário [Silva 90]. No Método Interativo, esquematizado na Figura 3.3, página 25, é o próprio SBD - ao invés do usuário - que interage com o componente de inferência [Kellogg 86]. 


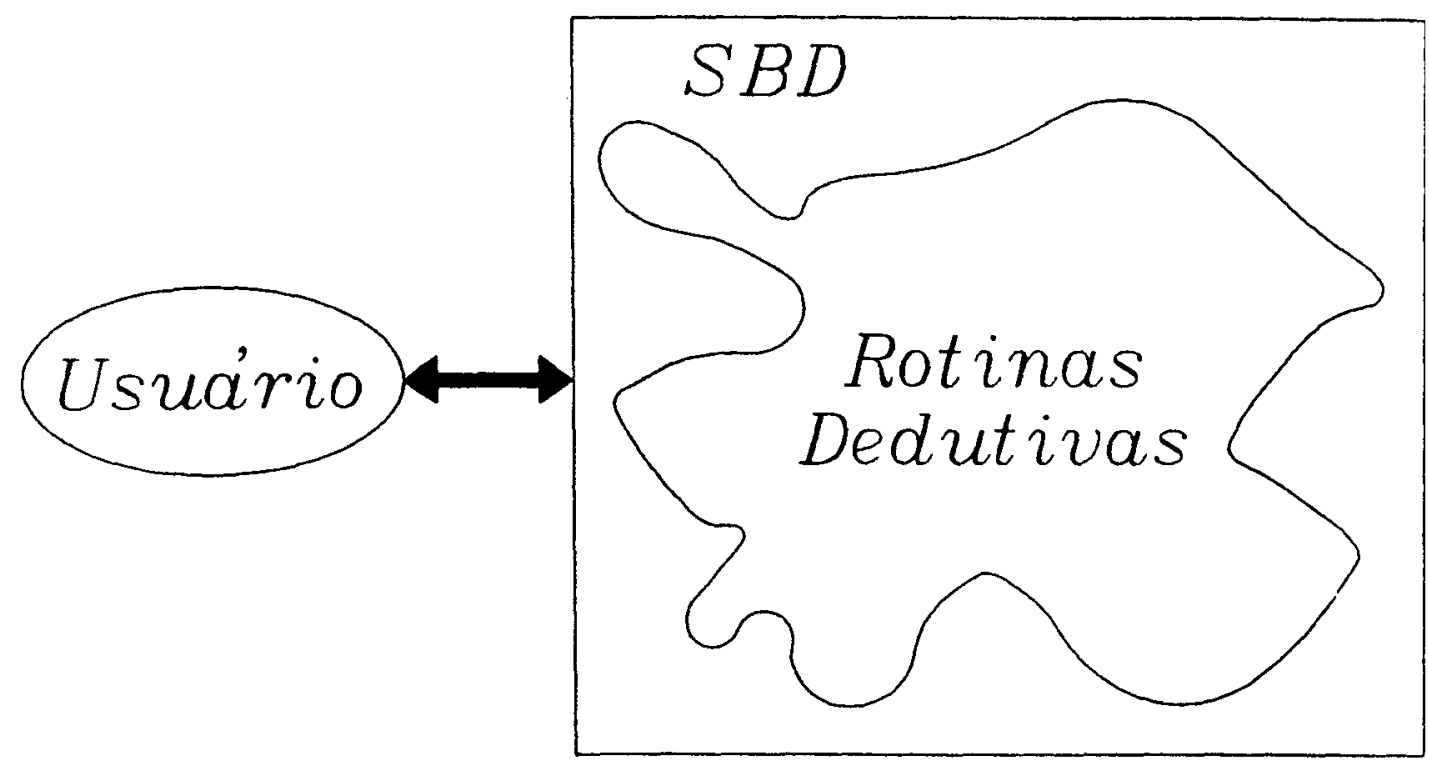

Figura 3.1: Método Integrado

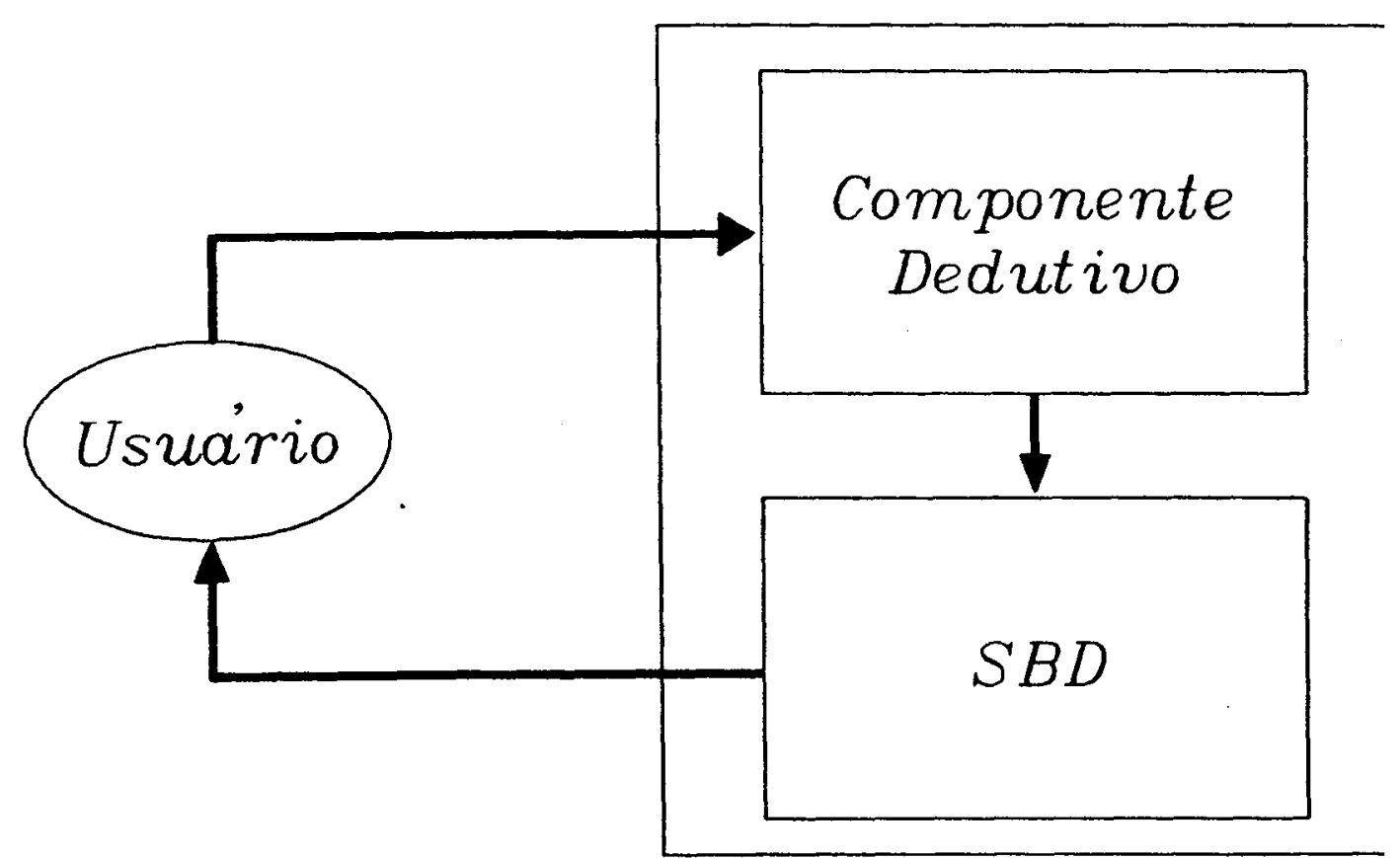

Figura 3.2: Método de Filtragem Dedutiva 


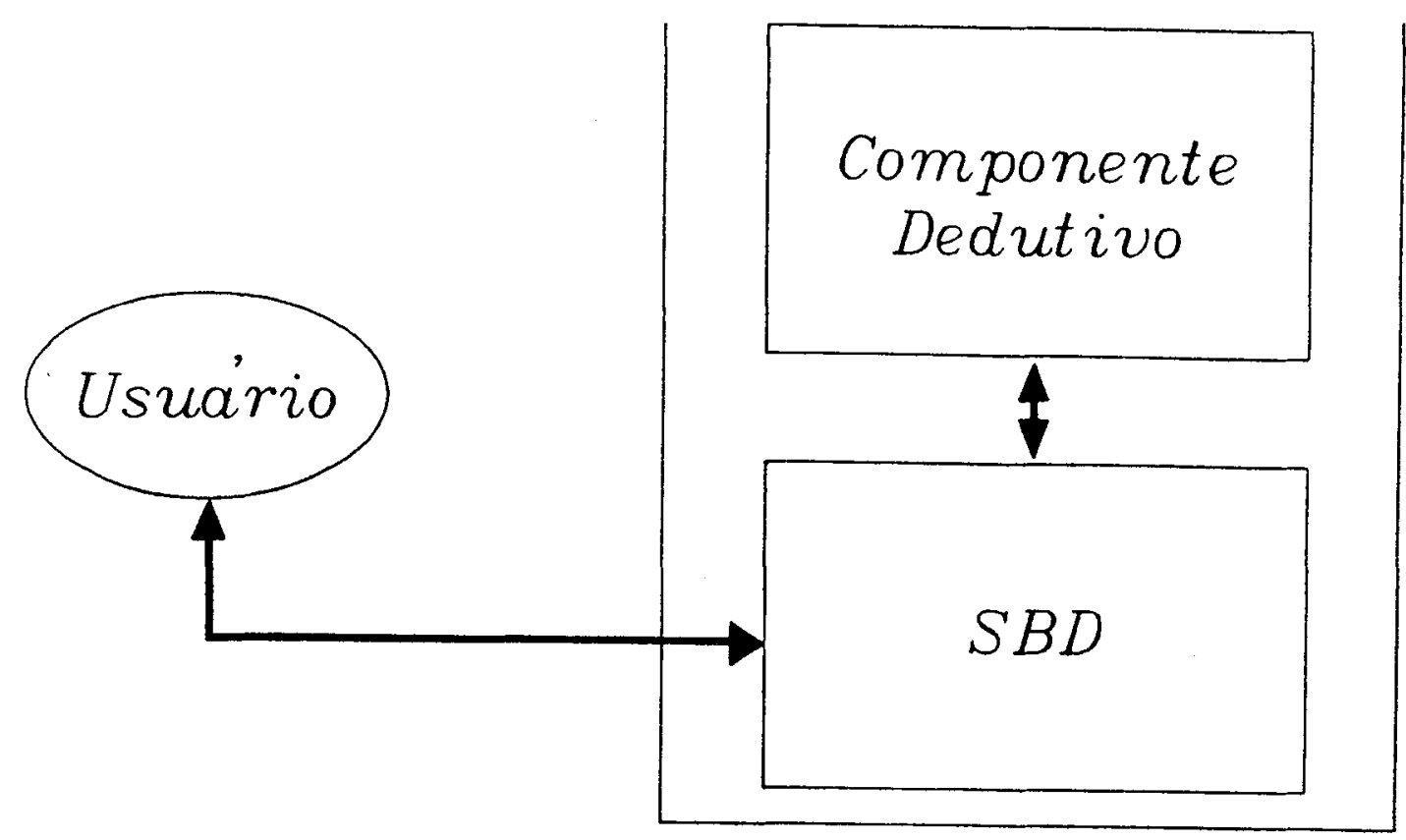

Figura 3.3: Método Interativo

\subsubsection{SBC Melhorado}

A classe anterior de sistemas envolve melhoramentos no Sistema de Base de Dados. Nesta segunda classe de sistemas, a otimização se localiza no Sistema Baseado em Conhecimento através da incorporação de facilidades extras de gerenciamento de dados. Isto é obtido de duas formas:

- Extensão de Linguagem e

- Suporte Geral ao SBD.

A Extensão de Linguagem consiste na ampliação da linguagem de programação na qual o SBC é escrito - Figura 3.4. Este tipo de interação é mais utilizado pelos sistemas escritos em linguagens de programação lógica [Gray 89a,Sciore 88] - e.g. Prolog.

Um abordagem mais ampla consiste em fornecer um Suporte Geral ao Sistema de Base de Dados, pois não envolve modificação direta nas linguagens de programação existentes [Gray $89 \mathrm{~b}$ ]. Ao invés disso, o componente de inferência do SBC é guarnecido com um mecanismo de acesso direto a um SBD generalizado, conforme mostra a Figura 3.5. 


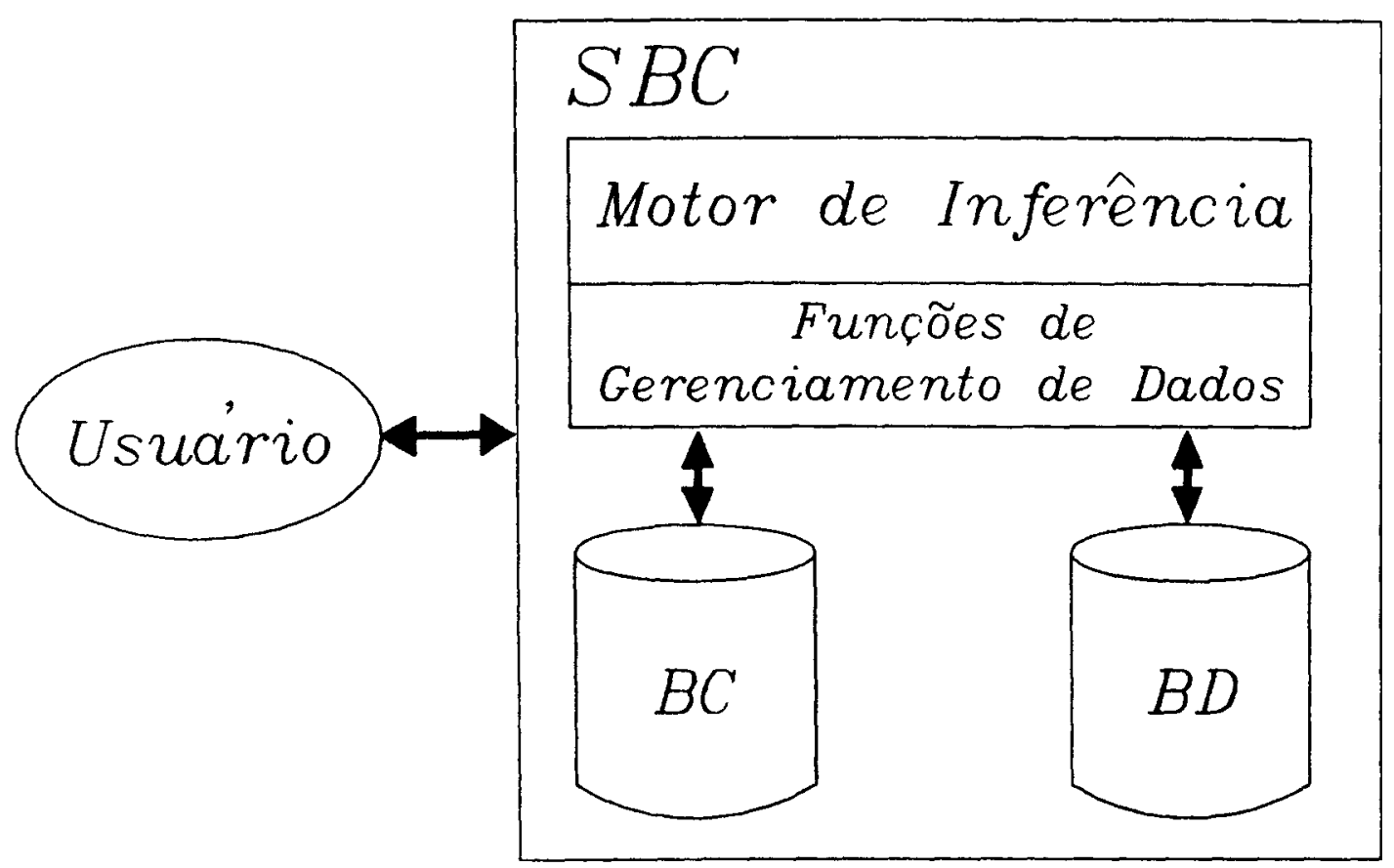

Figura 3.4: Extensão de Linguagem

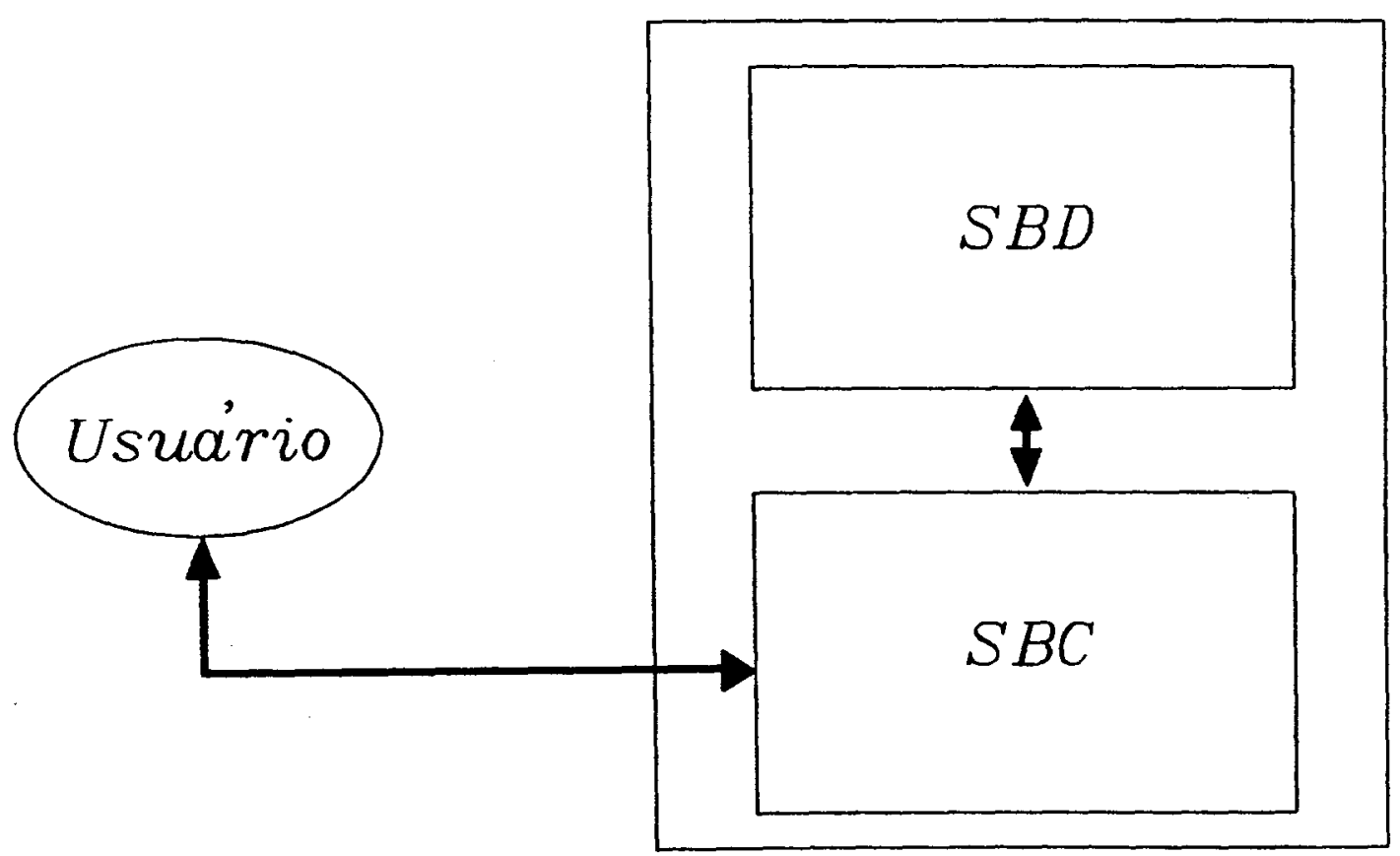

Figura 3.5: Suporte Geral ao SBD 
Nesse último caso, o acesso ao Sistema de Base de Dados é efetuado de duas maneiras:

- Os sistemas são fracamente acoplados, isto é, não há uma ligação dinâmica entre o Sistema de Base de Dados e o Sistema Baseado em Conhecimento. Neste caso, os dados são transferidos do SBD para o SBC antes do início da operação do último. Duplicações das informações são inerentes neste processo.

- Os sistemas são fortemente acoplados. Em tal situação, há uma conexão dinâmica entre eles. Os dados são recuperados do SBD apenas quando são necessários durante a operação do SBC. Isto pode acarretar um sobrecarga de processamento, pois cada vez que o SBC necessitar alguma informação, ele deve efetuar um acesso à Base de Dados através do Sistema Gerenciador de Base de Dados.

É claro que, embora um Sistema de Base de Dados de propósito geral seja utilizado, as Bases de Dados são completamente dedicadas ao Sistema Baseado em Conhecimento.

\subsubsection{Comunicação Intersistemas}

Como visto nas Seções 3.2.1 e 3.2.2, as formas de interação apresentadas envolvem melhorias ou no Sistema de Base de Dados ou no Sistema Baseado em Conhecimento. A terceira forma de interação permite que os dois sistemas coexistam independentemente um do outro, fornecendo alguma forma de comunicação entre eles.

Quando este tipo de interação é utilizado, é necessário decidir onde deve se localizar o controle geral - em particular, a localização do processamento e o controle da interação entre os dois sistemas. Isto pode ser obtido de três formas:

- Processamento e Controle Distribuídos;

- Processamento e Controle Locais e

- Processamento Distribuido Controlado por um Subsistema Independente. 


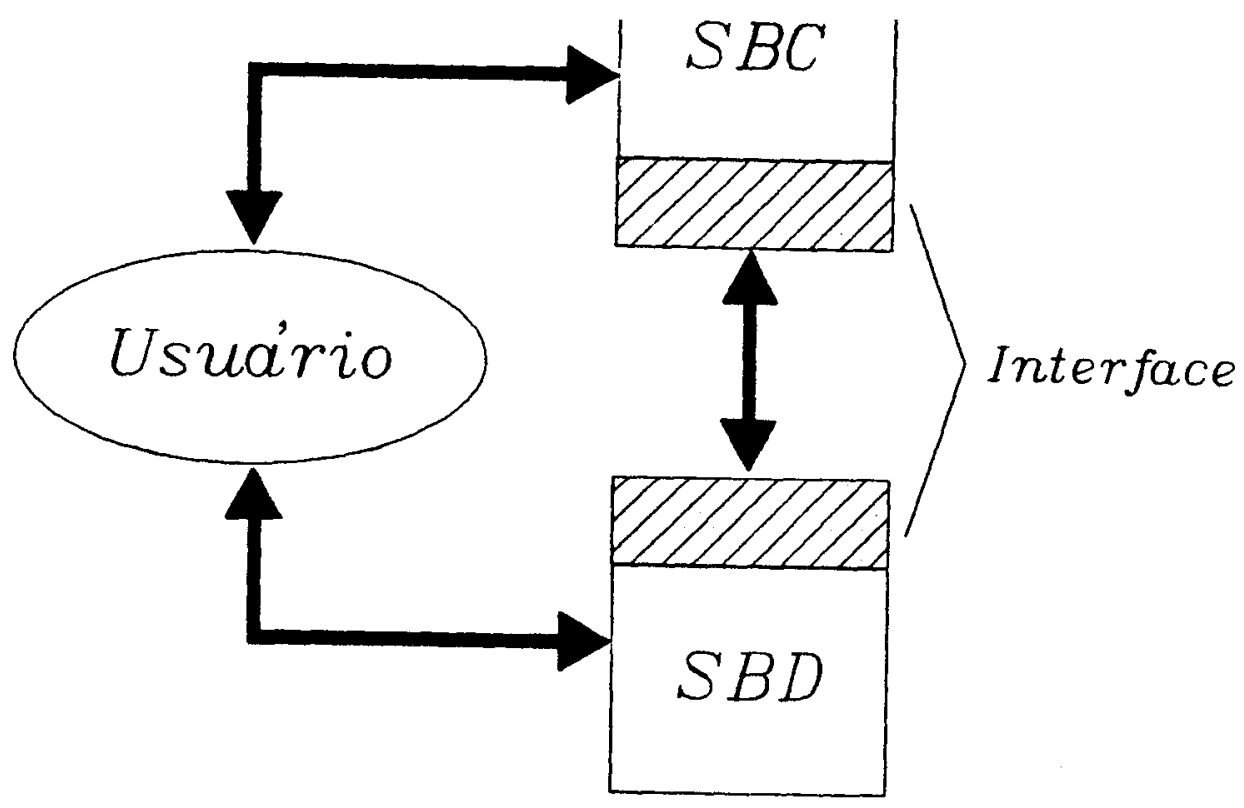

Figura 3.6: Processamento e Controle Distribuidos

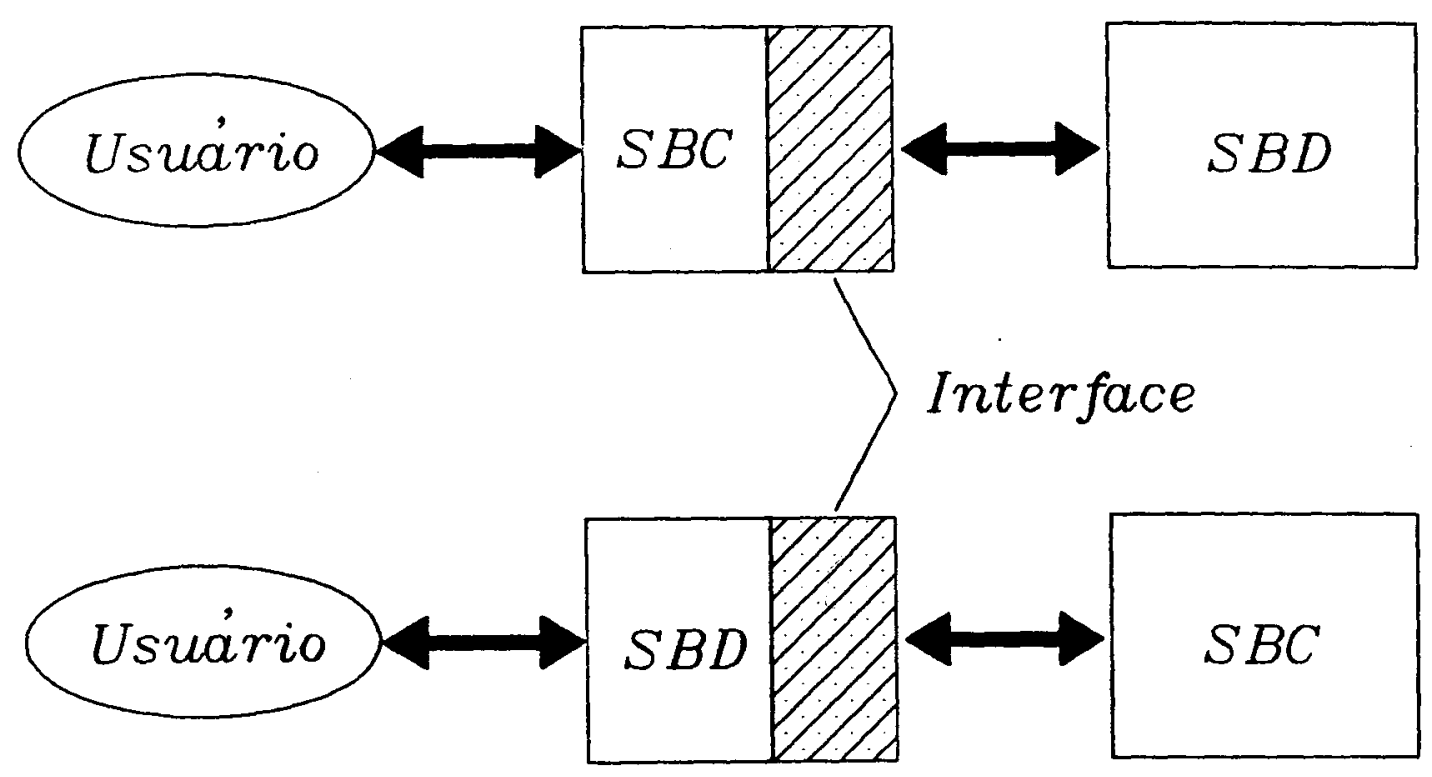

Figura 3.7: Processamento e Controle Locais 


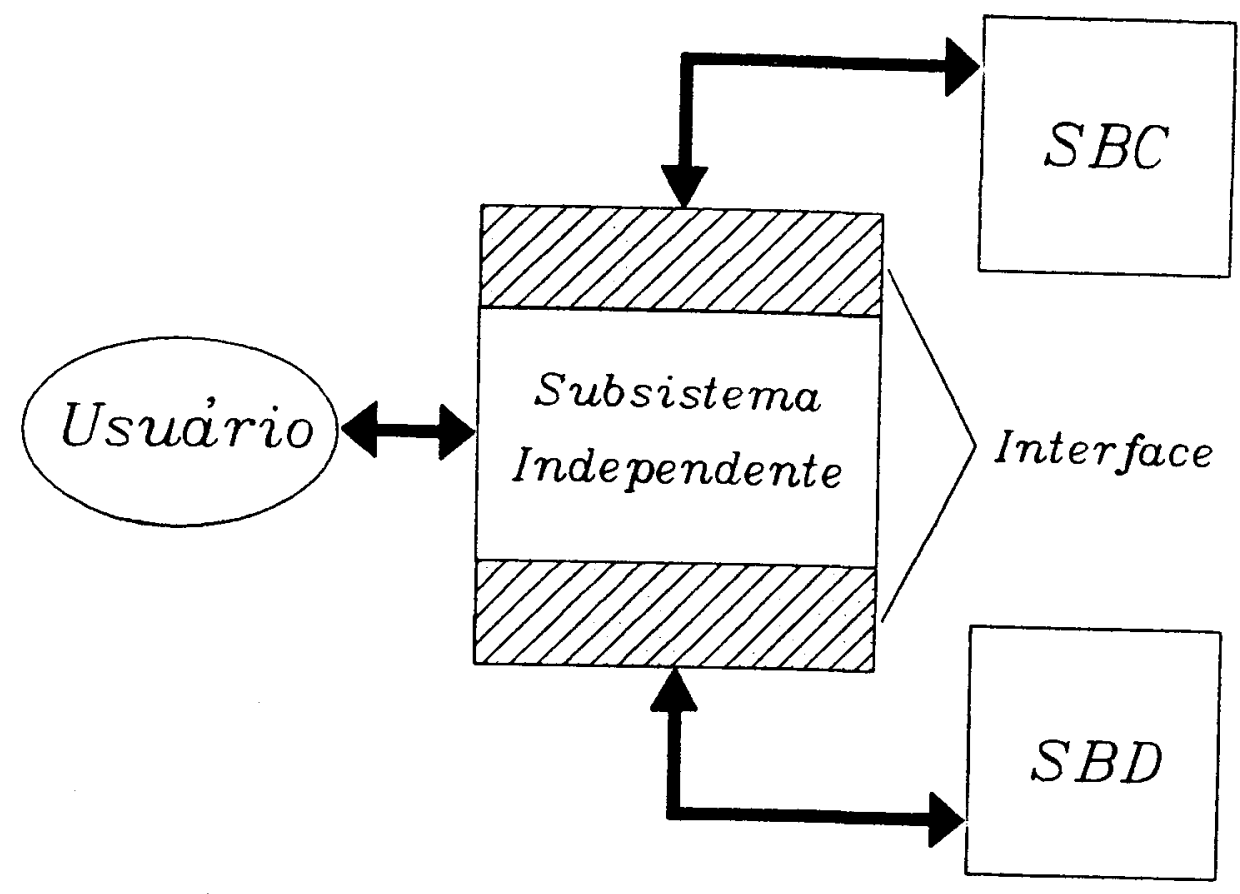

Figura 3.8: Processamento Distribuído Controlado por um Subsistema Independente

$\mathrm{Na}$ primeira abordagem - Figura 3.6 - os dois sistemas podem operar independentemente e toda interação entre eles é efetuada por passagem de mensagens [Schur 88]. Tal abordagem oferece independência da aplicação e sistema, podendo permitir a incorporação de outros Sistemas Baseados em Conhecimento e Sistemas de Base de Dados. Contudo, devido ao fato de ambos sistemas serem totalmente independentes um do outro, podem ocorrer problemas de inconsistência, incompatibilidade e redundância.

Na abordagem de Processamento e Controle Locais, conforme mostrada na Figura 3.7, um dos sistemas tem controle sobre o outro [Leung 90]. Isto oferece uma arquitetura mais flexivel, mas a integração de novos subsistemas é difícil.

A terceira abordagem tenta superar os problemas existentes nas duas abordagens anteriores. Aqui o processamento é distribuido mas o controle se localiza em um subsistema independente [Howard 89], como mostra a Figura 3.8.

\subsection{Considerações Finais}

Nos dias atuais, existe uma área grande e crescente de importância prática que nem os Sistemas Baseados em Conhecimento nem os Sistemas de Base de Da- 
dos separadamente podem satisfazer. Os Sistemas Baseados em Conhecimento existentes, enquanto podem utilizar algumas centenas ou milhares de peças de informação, não possuem a habilidade de procurar eficientemente e explorar quantidades da ordem de milhões ou bilhões de dados. De modo similar, os Sistemas de Base de Dados, embora tenham sido otimizados para lidar com grandes quantidades de dados comerciais e científicos, não foram projetados para enfrentar e manipular o tipo de informação encontrado nos SBCs.

Como cada vez mais os SBCs possuem Bases de Conhecimento fatual maiores, ao invés de impor todo o gerenciamento dessa grande quantidade de informação para ele - tarefa para o qual não foi originariamente definido - é conveniente a utilização de um SBD que efetua esse trabalho com muito melhor desempenho. Daí a importância em considerar-se a interação entre SBCs e SBDs.

Neste capítulo foram descritas diversas formas de interação entre esses sistemas. Foram ressaltadas as vantagens e desvantagens de cada uma das formas apresentadas em relação às demais. Como a aplicação desenvolvida neste trabalho faz uso de um Sistema de Base de Dados e de um Sistema Baseado em Conhecimento que interagem entre si, no Capítulo 7 é descrita a forma de interação - dentre aquelas aqui citadas - utilizada pelo sistema $\mathcal{O R I O N}$. 


\section{Capítulo 4}

\section{O Sistema SPIT}

\subsection{Considerações Iniciais}

O objetivo desse capítulo é o de apresentar o sistema São Paulo Interior Transplante - SPIT. São mostrados os elementos que o compõe, as funções desempenhadas por cada um e, por último, uma visão geral do ciclo de vida de pacientes receptores que fazem parte desse sistema.

Deve ficar claro que o objetivo deste capítulo é descrever aspectos administrativos, organizacionais e operacionais do sistema SPIT. Como esses aspectos diferem daqueles necessários para a aquisição de conhecimento para $O R I O N$, o capítulo seguinte é dedicado inteiramente a esse propósito.

\subsection{Composição}

O sistema SPIT foi criado com o objetivo de promover e dar condições ao desenvolvimento do transplante com rins de cadáver no estado de São Paulo, sendo composto por vários hospitais do estado.

Agrupando os hospitais e coordenando a forma pela qual os órgãos disponiveis são compartilhados entre eles, o sistema SPIT visa melhorar a qualidade de vida oferecida aos receptores que aguardam por um transplante, bem como aos pacientes já transplantados. Estudos realizados nessa área médica mostraram que compartilhando órgãos entre diversos centros hospitalares, realmente há um aumento na sobrevida dos receptores transplantados [Opelz 88]. 


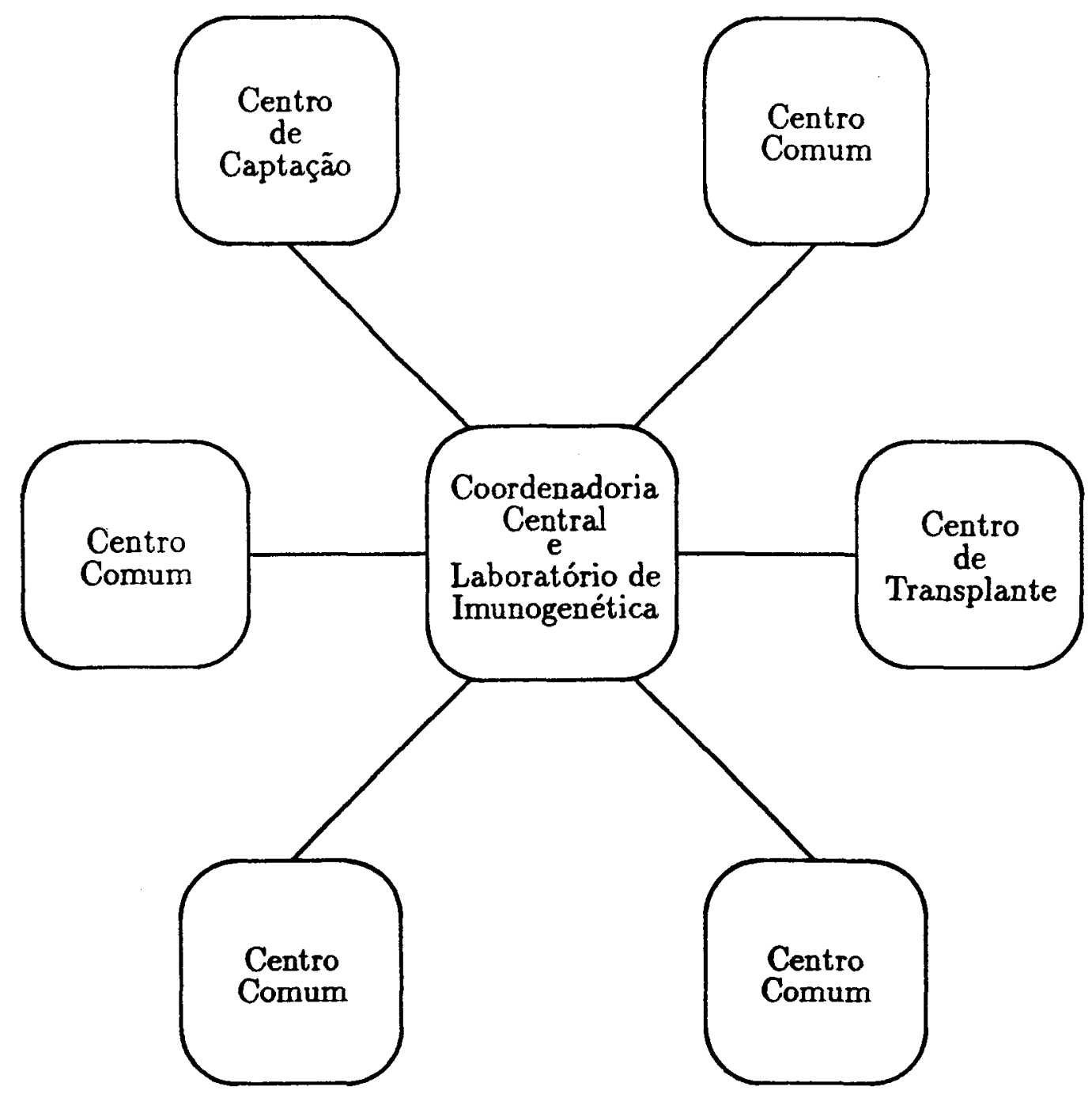

Figura 4.1: Componentes do Sistema SPIT

Os centros hospitalares associados ao SPIT são classificados da seguinte forma:

- Coordenadoria Central e Laboratório de Imunogenética;

- Centros de Transplante;

- Centros de Captação e

- Centros Comuns,

como pode ser observado na Figura 4.1. 
Os Centros Comuns são centros hospitalares que somente mantêm pacientes em tratamento à espera de transplante, realizando hemodiálises. Esses centros nâo possuem estrutura para a realização de transplantes.

Os Centros de Captação, além de exercerem as funções dos Centros Comuns, possuem a capacidade de captar, ou seja, retirar órgãos de doadores. Entretanto, não possuem condições para a realização de transplantes. Somando-se o número de Centros Comuns e Centros de Captação, atualmente existem vinte hospitais filiados ao sistema SPIT.

Os Centros de Transplante possuem estruturas mais sofisticadas, tais como laboratórios, aparelhos de Raios X, banco de sangue, etc. Esses centros exercem as funções dos Centros de Captação e, adicionalmente, sâo responsáveis pela realização de transplantes. Atualmente, existem quatro Centros de Transplante, distribuídos em três cidades:

- Ribeirão Preto:

口 Hospital das Clínicas - FMRP-USP;

口 Hospital São Francisco;

- Marília e

- São José do Rio Preto.

A função da Coordenadoria Central é atuar como coordenadora desse programa, recolhendo, controlando dados, mantendo a lista de pacientes receptores à espera de um transplante e realizando a seleção de receptores quando um órgão torna-se disponível. A Coordenadoria Central do SPIT está localizada no Hospital das Clínicas da Faculdade de Medicina de Ribeirão Preto - USP - HCFMRP. Devido a sua estrutura hospitalar, além de atuar como Coordenadoria Central, o HCFMRP realiza as atividades de um Centro de Transplante.

O Laboratório de Imunogenética é responsável pela realização dos exames imunológicos necessários para o processo de alocação de órgãos.

Cada hospital desejando integrar-se ao sistema SPIT é avaliado pela Coordenadoria Central. Sendo aprovada sua integração, o hospital então é cadastrado, tornado-se um Centro de Transplante, Centro de Captação ou um Centro Comum, de acordo com sua infra-estrutura.

Eventuamente, um centro integrante - Centro Comum, Centro de Captação ou Centro de Transplante - pode ser suspenso por decisão da Coordenadoria 


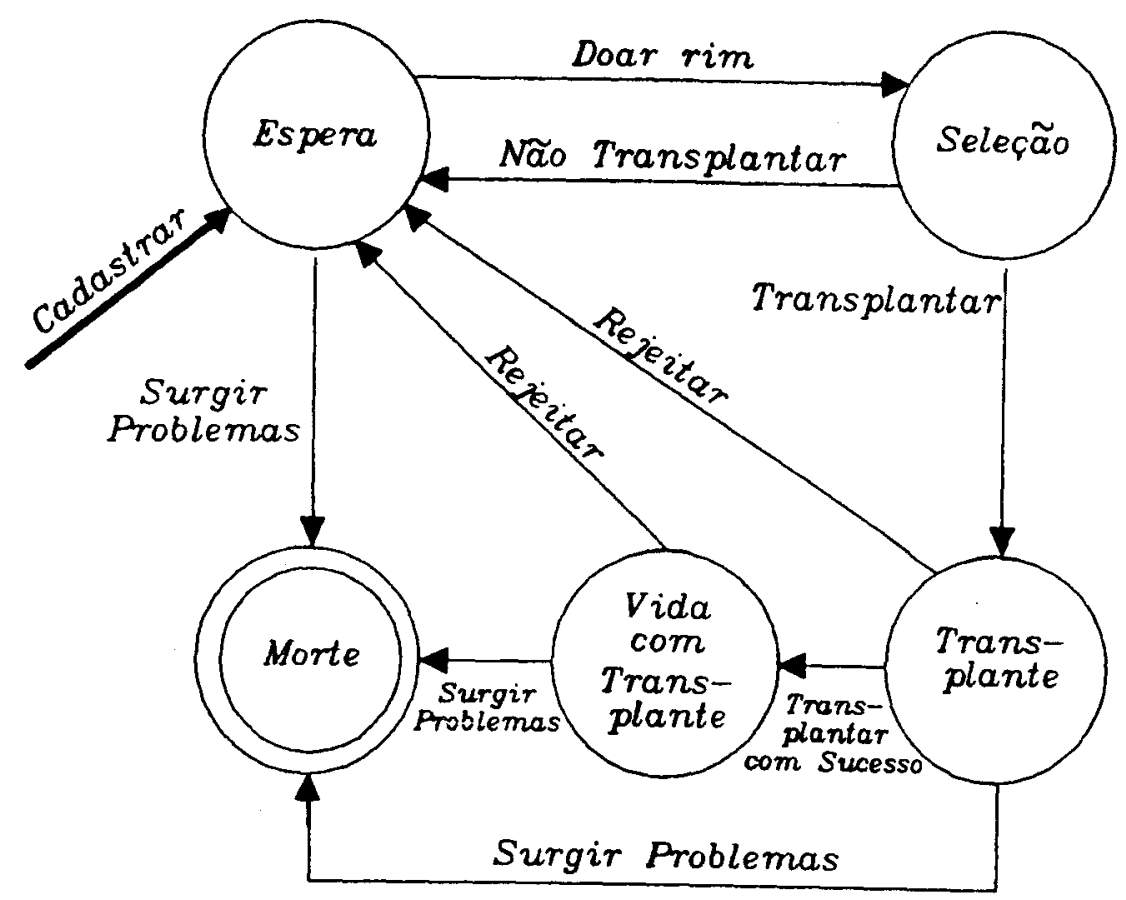

Figura 4.2: Ciclo de Vida de um Receptor no Sistema SPIT

Central devido a, por exemplo, não estar enviando relatórios periódicos sobre o estado de saúde dos seus pacientes. A suspensão de um centro integrante significa que nenhum de seus pacientes receberá um transplante até que a suspensão que foi aplicada sobre o centro seja retirada.

Para cadastrar receptores no sistema SPIT, os centros integrantes encaminham à Coordenadoria Central uma lista com dados de seus pacientes que necessitam um transplante. Cada paciente recebe um registro SPIT único e o centro recebe instruções para mandar sangue e soro para exames imunológicos. Dessa forma, pode-se notar que a Coordenadoria Central é responsável pelo gerenciamento dos receptores em potencial de vários hospitais do estado. O gerenciamento é efetuado através da criação de um único "banco de receptores" mantido pela própria Coordenadoria Central.

Casualmente, um receptor pode apresentar algum problema clínico que o impossibilita receber um transplante. Nesse caso, o receptor é suspenso do processo de alocação de órgãos até a solução do problema. Com isto, ele retorna da suspensão, tornando-se apto a ser selecionado para transplante - de modo análogo à suspensão e retorno de um centro integrante.

Quando um doador torna-se disponível, um processo de alocaşão é realizado selecionando-se, no máximo, dois receptores para receber os rins. 0 ciclo de vida de 
um receptor dentro do sistema SPIT, de uma maneira simplificada, é mostrado na Figura 4.2. Observa-se que a suspensão do receptor não foi considerada. Contudo, ela pode ser subentendida como parte de "Espera".

\subsection{Considerações Finais}

Nos dias atuais, em várias partes do mundo é comum encontrar-se, diariamente nos jornais, anúncios de indivíduos desesperados oferecendo um rim ou até mesmo um olho - para transplante de córnea - por dinheiro [TCOTTS 86]. Por outro lado, há pessoas que necessitam receber um transplante para poderem continuar vivendo.

Parece claro que quando o fato de melhorar as condições ou até mesmo salvar vidas é relegado às leis do comércio, particularmente quando o menos privilegiado é explorado para melhorar a saúde do mais privilegiado, todos na sociedade são diminuídos.

No entanto, é encorajador, para os indivíduos que necessitam um transplante renal e enriquecedor para os valores sociais, saber que existem pessoas responsáveis e interessadas em mudar essa perspectiva nada agradável.

Neste capítulo foram mostrados os componentes do sistema SPIT, seguindo-se uma descrição das funções desempenhadas por cada componente. Uma visão geral do ciclo de vida de cada receptor dentro do sistema foi estabelecida.

No capitulo seguinte são descritos os fatores que os especialistas do sistema SPIT utilizam para alocar os órgãos disponíveis aos receptores cadastrados; tal descrição corresponde à fase de aquisição de conhecimento para o sistema $\mathcal{O R I O N}$. 


\section{Capítulo 5}

\section{Fatores Considerados na Alocação de Rins}

\subsection{Considerações Iniciais}

Neste capítulo são descritos os fatores considerados no processo de alocação de rins pelo sistema SPIT, baseado principalmente em [Starzl 87]. Esse sistema tem como objetivo selecionar um receptor - proveniente do "banco de receptores", formado pelos pacientes dos vários hospitais filiados ao SPIT - no qual as chances de sucesso sejam as maiores possiveis, tentando diminuir as probabilidades de rejeição do órgão transplantado pelo receptor. $\mathrm{O}$ sucesso pode ser avaliado pela longevidade e pela qualidade de vida oferecida ao receptor transplantado.

Nas seções seguintes, deve ficar subentendido que sobrevivência do transplante significa sobrevivência tanto do receptor como do órgão transplantado como um todo e não apenas do órgão. Deve ficar implícito também que o fato de uma maior sobrevivência do transplante implica numa melhor qualidade de vida do receptor transplantado.

Deve-se deixar claro que a aplicação proposta respeita os critérios definidos pelo sistema SPIT. Mas não apenas isso. $\mathcal{O} \mathcal{L} \mathcal{\text { N }}$ amplia tais critérios no modo como podem ser utilizados, sendo mais flexível. Dessa forma, basta a Coordenadoria Central apenas restringir as extensões introduzidas em $\mathcal{O R I O N a}$ fim de selecionar receptores de acordo com os critérios por ela definidos.

Sempre que necessário são também citadas as diferenças e extensões do sistema $\mathcal{O} \mathcal{I} \mathcal{O N}$ em relação ao sistema TX3. 


\subsection{Agrupando os Fatores}

No processo de alocação de rins aos receptores no sistema SPIT, vários fatores sâo considerados. Durante o processo de aquisiçâo de conhecimento para este trabalho foi possivel notar que algo em comum existe entre determinados fatores. Foi com o objetivo de facilitar o entendimento e o estudo que tais fatores foram agrupados de acordo com os seguintes critérios:

- Fatores que, caso não satisfeitos, resultam na rejeição, imediata ou precoce, do órgão são denominados fatores primários;

- Fatores que influenciam na sobrevida do órgão transplantado a médio e longo prazo, sem contudo impedir que a cirurgia seja efetuada - ou seja, não causando rejeição precoce - são denominados fatores secundários e

- Fatores ligados a considerações humanas ou que atuam como um ponto de referência para os especialistas médicos são denominados fatores terciários.

Cada fator é satisfeito de modo diferente dos demais fatores. $\mathrm{O}$ significado de satisfazer tornar-se-á claro nas seções seguintes. Os fatores primários, secundários e terciários considerados pelo SPIT são os seguintes:

1. Fatores Primários:

口 Grupo $A B O$,

口 Cross-Match e

口 $H L A$.

2. Fatores Secundários:

- Transfusões;

口 Retransplantes;

- Painel;

- Gestações e

口 Distância entre Doador e Receptor.

3. Fatores Terciários:

- Tempo de Hemodiálise;

口 Urgência Médica;

- Idade do Receptor e

口 Tempo de Espera do Receptor por um Órgão. 


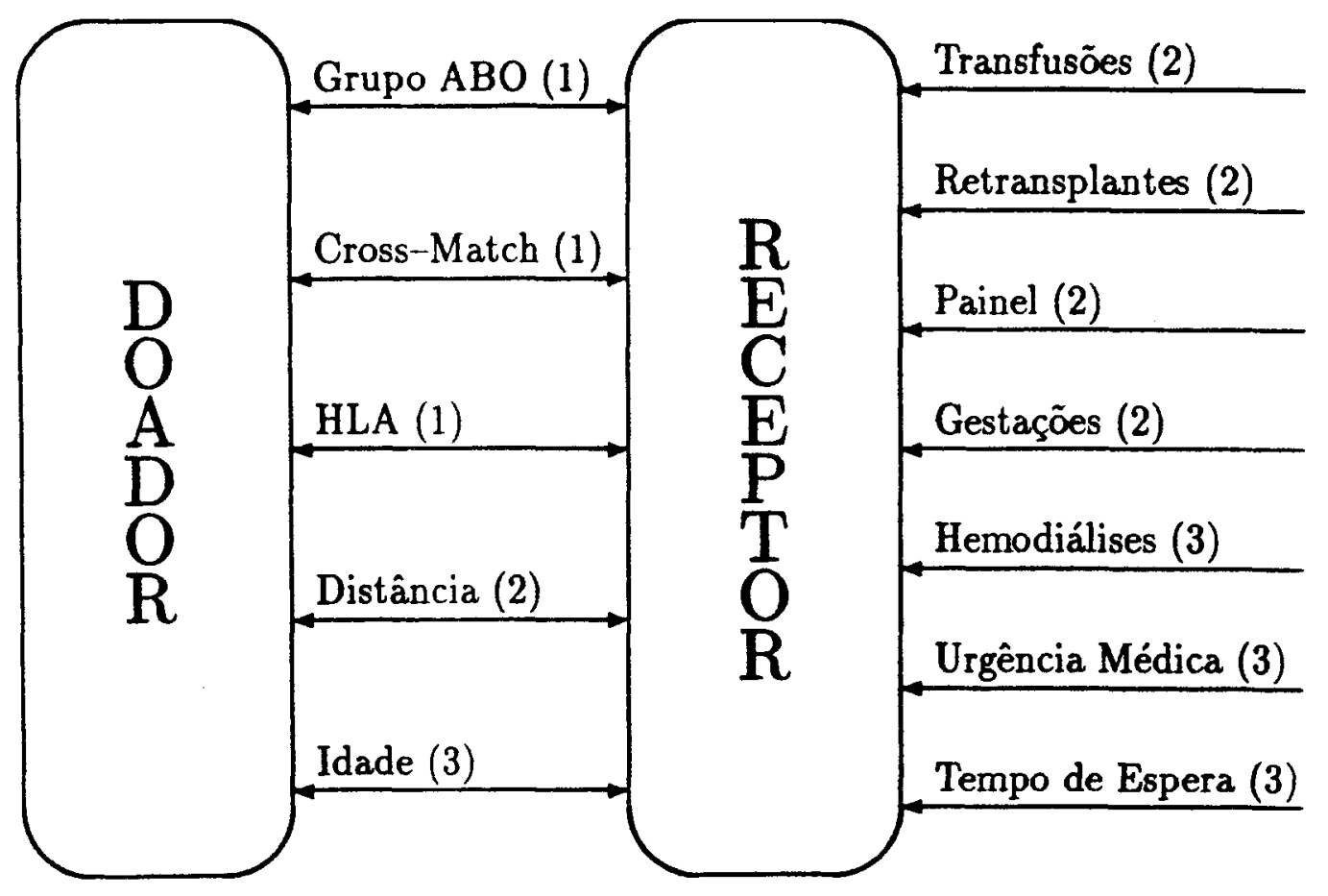

Figura 5.1: Fatores Considerados na Alocação de Receptores

Esse agrupamento é, realmente, muito conveniente, facilitando muito durante a fase de estruturação do conhecimento - descrita no Capítulo 6.

A Figura 5.1 mostra a relação entre os fatores, doador e receptor. Os números entre parênteses indicam se o fator é primário (1), secundário (2) ou terciário (3). As linhas existentes entre doador-receptor indicam que existe uma relação entre seus respectivos fatores. As linhas conectadas apenas ao receptor indicam que tais fatores estão relacionados somente com ele.

\subsection{Fatores Primários}

Os fatores primários, descritos a seguir, resultam na rejeição imediata ou a curto prazo do rim após a cirurgia, caso não sejam satisfeitos. Os três fatores primários considerados são:

- Grupo $A B O$;

- Cross-Match e

- HLA. 


\subsubsection{Grupo $A B O$ (Grupo Sangüíneo)}

Dentre os diversos tecidos que compöem o corpo humano, existe um denominado Tecido Sangüíneo que, de uma maneira simplificada, é assim constituído:

- Parte Líquida:

口 Plasma.

- Parte Sólida:

口 Leucócitos ou Glóbulos Brancos;

- Plaquetas e

口 Hemácias ou Glóbulos Vermelhos.

Basicamente, os leucócitos são responsáveis pela defesa do organismo. As plaquetas têm a função de realizar a coagulação sangüínea. As hemácias realizam o transporte de gases pelo organismo.

As hemácias contêm antígenos - substâncias de natureza protéica capazes de, penetrando no organismo dos seres vivos, provocar a formação de anticorpos - denominados aglutinogênios, na superfície de suas células. Os antígenos dos glóbulos vermelhos são responsáveis pelos diferentes grupos sangüíneos. É importante salientar que esses antígenos também estão presentes em outras células do organismo, e.g. nas células dos pulmöes, dos rins, etc.

Por outro lado, no plasma sangūíneo podem existir anticorpos - substâncias responsáveis pela defesa do organismo - contra esses aglutinogênios. Por essa razão, os individuos de grupos sangüíneos incompativeis não podem doar sangue entre si. Caso isso seja efetuado, ou seja, uma vez colocados em contato o anticorpo com seu antígeno específico, ocorre aglutinação dos glóbulos vermelhos causando sérios riscos ao organismo do indivíduo.

Existem dois tipos de aglutinogênio encontrados nas hemácias, identificados pelas letras $A$ e $B$. Se uma pessoa possuir apenas um desses aglutinogênios, seu sangue é classificado como sendo do grupo $A$ ou $B$, conforme o caso. Quando uma pessoa possui os dois, seu sangue é classificado como sendo do grupo $A B$; por último, se não possuir nenhum, seu sangue é classificado como sendo do grupo $O$.

A Tabela 5.1 mostra como o fato de pertencer a diferentes grupos sanguíneos condiciona a possibilidade de doar ou receber sangue. As entradas da tabela 


\begin{tabular}{|c||c|c|c|c|}
\hline \multicolumn{1}{|c||}{ Grupo ABO } & \multicolumn{4}{c|}{ Receptor } \\
\hline Doador & A & B & AB & O \\
\hline \hline A & $\odot$ & & $\odot$ & \\
\hline B & & $\odot$ & $\odot$ & \\
\hline AB & & & $\odot$ & \\
\hline O & $\odot$ & $\odot$ & $\odot$ & $\odot$ \\
\hline
\end{tabular}

Tabela 5.1: Esquema das Possíveis Transfusôes entre os Grupos Sangüineos

marcadas com o símbolo $\odot$ indicam transfusão de sangue entre grupos compatíveis entre si. As entradas vazias indicam uma incompatibilidade sanguínea, ou seja, a transfusão não pode ser efetuada.

Assim, segundo a Tabela 5.1, um doador pertencente ao grupo $A$ pode fornecer sangue para pessoas dos grupos $A$ e $A B$ (primeira linha); por outro lado, uma pessoa do grupo $A$ pode receber sangue de pessoas dos grupos $A$ e $O$ (primeira coluna). Aquelas pessoas que possuem o grupo sangüíneo $A B$ podem receber sangue de qualquer outro grupo - são receptoras universais; pessoas de grupo sangüineo $O$ podem doar para qualquer outro grupo - são doadoras universais.

Num transplante, uma incompatibilidade $A B O$ resulta na rejeição imediata do órgão pelo receptor. Dessa forma, é necessário que doador e receptor possuam compatibilidade no sistema $A B O$ para que o transplante possa ser efetuado. Ressalta-se que a compatibilidade corresponde às entradas preenchidas na Tabela 5.1. A igualdade sanguínea corresponde somente à diagonal principal.

O sistema TX3, utilizado pelo sistema SPIT, considera a compatibilidade sangüinea entre doador e receptor na alocação de orgãos. $O$ sistema $\mathcal{O R I O N}$ permite considerar, além da compatibilidade, a igualdade entre o grupo $A B O$, deixando a decisão de utilizar ora uma ora outra a cargo da Coordenadoria Central.

O fato de utilizar-se a compatibilidade ou igualdade pode ser explicado observando-se a Tabela 5.1. É fácil perceber que uma pessoa do grupo $O$ é um doador universal, mas pode receber sangue apenas do seu próprio grupo. Isso implica que, utilizando-se o critério de compatibilidade sangüinea, numa seleção de receptores para transplante, aqueles do grupo $O$ são prejudicados: eles compartilham rins com os demais receptores. Com os demais grupos sangüineos, entretanto, isso não ocorre. 


\section{Fator $R h$}

Do mesmo modo que o sangue é classificado nos grupos $A, B, A B$ e $O$, ele também pode ser classificado atendendo a um outro critério que indica a presença ou não de uma substância chamada de fator $R h$. Quando um indivíduo possui tal substância, é classificado como um indivíduo $R h$ positivo - $R h^{+}$. Caso não possua, é classificado como $R h$ negativo - $R h^{-}$. O fator $R h$ é independente da classificação $A B O$.

Devido ao fato de não ter sido comprovada, até o presente momento, uma influência evidente do fator $R h$ no sucesso do transplante renal, ele não é considerado no processo de alocação de órgãos no sistema TX3. Entretanto, como uma extensão do sistemá TX3, o fator $R h$ é considerado no sistema $\mathcal{O R I O N}$. Caberá à Coordenadoria Central decidir se e quando utilizá-lo.

\subsubsection{Cross-Match}

O Cross-Match é um teste que verifica, no receptor, a presença de anticorpos préformados contra antígenos $H L A$ - Seção 5.3.3 - das células do doador. Para tal finalidade, o soro dos receptores é armazenado até a disponibilidade de um órgão.

$\mathrm{Na}$ disponibilidade de um doador, o Cross-Match é realizado num subconjunto da população de receptores. Esse subconjunto é determinado, pelo sistema TX3, selecionando-se os dez primeiros pacientes - incluindo aqueles com a mesma classificação do décimo colocado - que possuem maior compatibilidade com os antígenos $H L A$ desse doador específico. $\mathrm{O}$ número limitante igual a dez é devido à quantidade de tempo e ao custo necessários para a realização desse teste.

Uma vez realizado, o Cross-Match possui dois resultados possíveis: negativo ou positivo. Um resultado positivo contra indica o transplante; ocorrerá rejeição do órgão pelo receptor caso o transplante seja efetuado. Um Cross-Match negativo dos receptores em potencial deve ser obtido antes do transplante do órgão.

No sistema SPIT, o soro de cada paciente - contido em frascos de vidro de pequeno tamanho - é rotulado com a data da retirada do soro do receptor, as iniciais do seu nome e seu número de registro SPIT. Após ser rotulado, o soro é armazenado em embalagens de isopor em ambiente refrigerado.

Com esse processo de refrigeração, o soro de cada receptor poderia ser armazenado por um prazo relativamente grande. Contudo, como o soro deve refletir a condição 
imunológica do paciente, ele é armazenado por noventa dias. Após esse intervalo de tempo, o soro deve ser renovado, pois supóe-se que a imunologia do paciente alterou-se durante esse intervalo de tempo - por exemplo, através de transfusões de sangue. Essa renovação é efetuada retirando-se uma nova quantidade de soro do receptor.

Como o Cross-Match só pode ser efetuado com soro dentro do prazo de validade, todos os receptores que possuem soro com validade vencida são excluídos do processo de alocação até a renovação de seu soro.

Diferentemente do sistema TX3, o sistema aqui proposto permite que:

- o prazo de validade do soro de cada receptor e

- o número de receptores a serem selecionados para Cross-Match

sejam alterados, segundo o entender da Coordenadoria Central. ORION também considera, além da compatibilidade $H L A$ entre doador e receptor, os demais fatores na seleção dos pacientes para Cross-Match.

\subsubsection{HLA}

Todas as características que os seres vivos apresentam são determinadas por agentes localizados nos cromossomos existentes no núcleo das células. Esses agentes são denominados gens ou genes. Cada gen ocupa um lugar definido - ou locus - no cromossomo.

Os cromossomos, existentes aos pares, que possuem a forma ligeiramente igual com a mesma sequêencia de gens, originários cada um de um dos pais, são denominados cromossomos homólogos. Cada cromossomo do par homólogo é chamado haplótipo. Em um par de cromossomos homólogos, os gens que se localizam no mesmo lugar em cada cromossomo e são responsáveis pelo mesmo tipo de característica são denominados gens alelos - Figura 5.2. Para cada característica exibida por uma pessoa, existe um par de gens, um gen em cada cromossomo, responsável por ela.

De maneira geral, um dos gens exerce uma dominância sobre seu alelo, ou seja, um dos gens pode impedir que a característica do seu alelo se manifeste. $\mathbf{O}$ gen que exerce dominância sobre seu alelo é chamado de gen dominante; o outro gen é dito recessivo. 


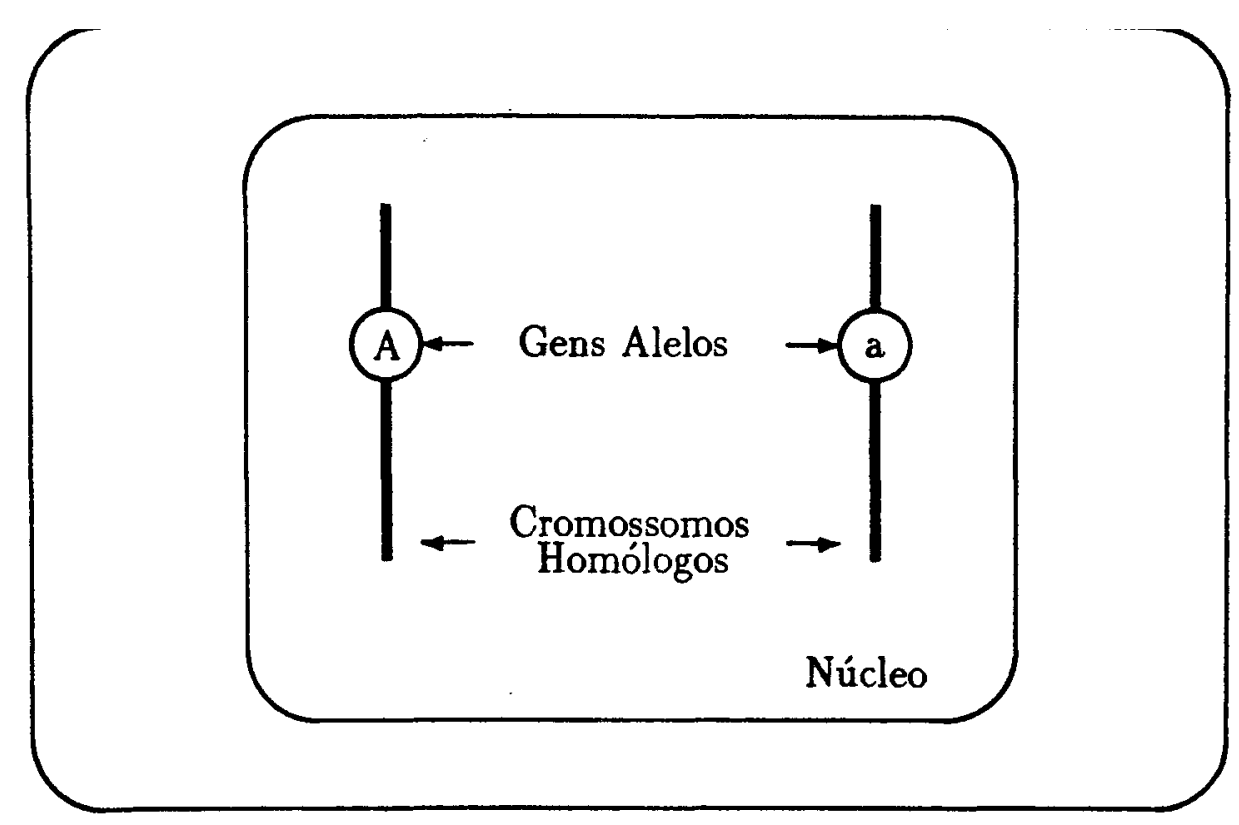

Figura 5.2: Célula Mostrando um Par de Cromossomos Homólogos

Essa dominância de um gen sobre seu alelo significa que as características exibidas por um organismo são determinadas pelos gens dominantes. As características dos gens recessivos ficam ocultas na existência do gen dominante e só são notadas quando o gen dominante não está presente. Na Figura 5.2, o gen dominante é indicado por uma letra maiúscula e o gen recessivo por uma letra minúscula.

Supondo que o gen rotulado com a letra $\mathbf{A}$ determine a cor do olho como sendo marrom e a letra a determine a cor do olho como sendo azul, o individuo que possui o genótipo - característica herdada através dos gens - AA ou Aa terá olhos de cor marrom, pois o gen que determina a cor marrom exerce dominância sobre o gen que determina a cor azul dos olhos. $O$ indivíduo com genótipo aa terá olhos azuis. $O$ indivíduo que possui suas células iguais àquela mostrada na Figura 5.2 - genótipo Aa - terá olhos de cor marrom.

Como citado na Seção 5.3.1, página 39, na natureza existem substâncias de origem protéica capazes de provocar a formação de anticorpos - os antígenos. Existem, contudo, antígenos que os filhos herdam dos pais através dos gens ao invés de serem introduzidos no organismo de uma outra forma qualquer. 
Os antígenos $H L A$,

$$
\begin{aligned}
& \mathrm{H}=\text { Humano } \\
& \mathrm{L}=\text { Leucócito } \\
& \mathrm{A}=\text { Antígeno }
\end{aligned}
$$

são desse último tipo. Dentre os antígenos $H L A$, três loci são considerados na seleção de receptores:

$$
H L A-A, H L A-B \text { e } H L A-D R
$$

Como os cromossomos existem aos pares homólogos, cada ser humano possui um $H L A-A$ originário do pai e outro $H L A-A$ proveniente da mãe; o mesmo é válido para $H L A-B$ e $H L A-D R$. Existem mais de 80 gens alelos diferentes para os loci $H L A-A, H L A-B$ e $H L A-D R$. Como descrito anteriormente, geralmente um dos gens exerce uma dominância sobre seu alelo. Isso, todavia, não ocorre com os antígenos $H L A$, ou seja, os genes são co-dominantes, o que confere um grande polimorfismo ao sistema $H L A$. A Figura 5.3 mostra a herança de haplótipos $H L A$. Cada indivíduo possui dois haplótipos: no homem mostrado eles são

$$
A=8, B=15, D R=3 \quad \text { e } \quad A=1, B=5, D R=2
$$

Se rotular-se o haplótipo do pai como ab e o haplótipo da mãe como $c d$, seus filhos podem ser apenas de quatro tipos:

$$
a c, a d, b c \text { e } b d
$$

Os filhos,

$$
\begin{array}{lll}
a c & \mathrm{e} & a d \\
b c & \mathrm{e} & b d \\
a c & \mathrm{e} & b c \\
\mathrm{ad} & \mathrm{e} & b d
\end{array}
$$

são $H L A$ semi-idênticos, ou seja, possuem um haplótipo diferente. 


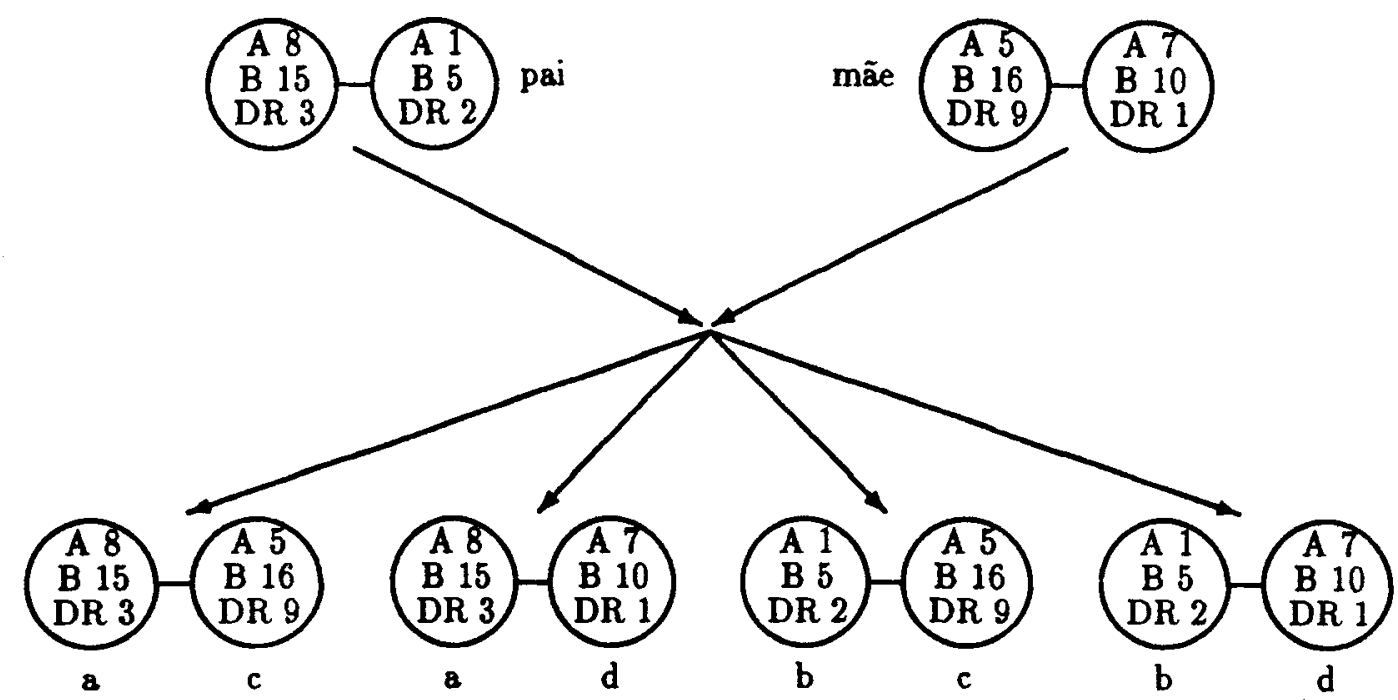

Figura 5.3: Herança de Haplótipos HLA

É importante ressaltar que os números atribuidos aos gens são apenas rótulos. Assim, não existe uma medida de proximidade ou compatibilidade entre os diversos antígenos $H L A$.

Por exemplo, caso três pessoas $\mathrm{X}, \mathrm{Y}$ e $\mathrm{Z}$ possuam em um de seus loci:

$$
\mathrm{X} \equiv H L A-A=28, \quad \mathrm{Y} \equiv H L A-A=29 \quad \text { e } \quad \mathrm{Z} \equiv H L A-A=35
$$

não se pode afirmar que $X$ é mais compativel com $Y$ ( "distância" $=29-28=1$ ) do que com Z ( "distância" = 35-28 = 7).

Segundo alguns estudos realizados por [Gabriel 85], tem-se que:

- Transplante entre gêmeos idênticos possui um resultado muito favorável;

- A sobrevivência do transplante entre duas pessoas que são $H L A$ idênticos - dois haplótipos iguais - é quase tão favorável como no caso anterior;

- A sobrevivência do transplante entre pessoas com um haplótipo em comum é cerca de $75 \%$ em 3 anos;

- Para pessoas sem haplótipos em comum, a sobrevivência do transplante cai para cerca de $60 \%$; 
- O $H L A-D R$ é, provavelmente, o majs importante em termos de forçar a indução de rejeição; $H L A-B$ é o segundo mais importante e, por último, $H L A-A$ é o terceiro mais importante. Igualdade no $H L A-D R$ entre doador e receptor deve ser obtida para sobrevivência prolongada do órgão e

- A identidade do $H L A$ é independente do grupo $A B O$.

\section{Splits}

Na população humana, pode-se perceber a diversidade de pessoas existentes. Embora, como um todo, uma pessoa difira completamente de outras, é possível notar semelhanças em partes do corpo humano entre alguns indivíduos. Por exemplo, uma pessoa pode possuir o formato dos olhos - ou de outra parte qualquer do organismo - muito parecido com o de outra pessoa, mesmo que não sejam parentes.

De modo análogo, isso acontece com os antígenos $H L A$. Alguns gens desses loci possuem subunidades que se assemelham com outros antigenos $H L A$. Essas subunidades são denomindas Splits. Um antígeno $H L A$ pode possuir no máximo dois Splits.

A notação utilizada para indicação dos Splits é a seguinte:

$$
\begin{array}{ll}
x(y, z) & y \text { e } z \text { são Splits de } x . \\
x(y) & y \text { é Split de } x .
\end{array}
$$

Por exemplo, um $H L A-A=9(23,24)$ indica que o antígeno 9 possui subunidades que se assemelham com os antígenos 23 e 24 .

Os Splits são mantidos como parte integrante dos dados do receptor pelo sistema SPIT, contudo não são considerados na seleção de receptores para transplante no sistema TX3.

No sistema $\mathcal{O} \mathcal{I} \mathcal{N}$, essas subunidades são consideradas no processo de alocação de órgãos uma vez que, de acordo com os especialistas do SPIT, há um aumento na sobrevida dos receptores quando os Splits são utilizados. 


\subsection{Fatores Secundários}

Como explanado na Seção 5.2, os fatores secundários são aqueles que, caso satisfeitos, aumentam as chances de sucesso do transplante a médio ou longo prazo. Tajs fatores:

- Transfusões;

- Retransplantes;

- Painel;

- Gestações e

- Distância entre Doador e Receptor

são detalhados nas seções seguintes.

\subsubsection{Transfusōes}

Aproximadamente há duas décadas atrás, os especialistas em transplante renal observaram que os pacientes que haviam recebido algumas transfusões de sangue pré-transplante - não imediatamente antes, mas num período de dias ou meses antes do transplante ser efetuado - possuiam uma probabilidade maior de manter o rim funcionando e, conseqüentemente, de sucesso no transplante do que pacientes que não haviam recebido sangue no periodo pré-operatório.

Estudos posteriores mostraram que realmente as transfusões pré-transplante, de alguma forma, aumentavam as chances de sobrevivência a longo prazo do transplante. Isso é aparentemente contraditório, pois como o receptor entra em contato com sangue de diversos individuos, e assim com vários antígenos, existe a possibilidade dele formar muitos anticorpos. Isso pode torná-lo hipersensibilizado contra grande parte da população e, portanto, com majores chances de rejeitar um transplante. Esse aparente paradoxo não está totalmente explicado pela Imunologia.

Dependendo de decisão da Coordenadoria Central, pode exigir-se que cada receptor receba um número mínimo de transfusões antes de realizar um transplante. $\mathrm{Na}$ época da publicação de [SPIT 89], três transfusões eram exigidas antes do transplante. Atualmente, essa restrição não mais existe [SPIT 91]. Isso é devido 
ao fato que a Coordenadoria Central deseja futuramente verificar qual a influência real do número de transfusões na sobrevida receptor-órgão transplantado.

O sistema TX3, entretanto, não permite que o número mínimo de transfusões seja alterado facilmente. No trabalho proposto, é possivel modificar esse número de forma que os receptores cadastrados que não possuam essa quantidade mínima de transfusões sejam excluídos do processo de alocação de órgãos.

\subsubsection{Retransplantes}

De modo análogo ao explicado na seção anterior, o número de retransplantes está relacionado a uma maior formação de anticorpos no receptor contra antígenos $H L A$ do doador. No sistema SPIT, o paciente que já passou por pelo menos um transplante, deve ter, no mínimo, compatibilidade total nos loci $H L A-D R$ e $H L A-B$ para efetuar um retransplante.

No sistema $\mathcal{O} \mathcal{R} \mathcal{I} \mathcal{N}$, o número mínimo de compatibilidade em cada locus $H L A$ para receptores retransplantados pode ser alterado pela Coordenadoria Central. No sistema TX3 isso não ocorre.

\subsubsection{Painel}

Painel é um exame que tem como objetivo identificar o grau de sensibilização que cada receptor possui em relação aos antígenos $H L A$ da população humana. Para fins práticos, a quantidade de anticorpos pré-formados contra as células de uma população de 30 indivíduos - que, geralmente, não possui nenhum vínculo com a população de receptores - é medida em todos os receptores em potencial no sistema SPIT. A quantidade desses anticorpos é expressa como um número porcentual, denominado Panel Reactive Antibody number-PRA.

Dessa forma, o PRA tem como objetivo indicar a porcentagem da população contra a qual um receptor possui anticorpos. Assim, um indivíduo com um PRA de $0 \%$ não está sensibilizado; um paciente com um $P R A$ de $100 \%$, indica sensibilização e formação de anticorpos contra toda a população. Quanto major o PRA maior a sensibilização do receptor contra o $H L A$ de toda a população.

Atualmente no sistema SPIT, para um PRA major ou igual a 50\%, indicando sensibilização do receptor com mais da metade da população - no mínimo quatro compatibilidades $H L A$ são necessárias para o transplante: duas no locus 
$H L A-D R$ e duas no locus $H L A-B .0$ soro que forneceu o major $P R A$ de cada receptor é armazenado para uma comparação futura feita pelos especialistas.

$\mathrm{Na}$ aplicação aqui proposta, o número de compatibilidades necessárias em cada locus $H L A$ para transplante em um receptor com $P R A \geq 50 \%$ pode ser alterado pela Coordenadoria Central. Mas não apenas isso. A porcentagem demilitadora, atualmente igual a $50 \%$, também poder ser alterada. Novamente, essa facilidade não está disponível no sistema TX3.

\subsubsection{Gestações}

O número de gestações tem como finalidade explicar um $P R A$ muito grande, pois tende a aumentar a formação de anticorpos na mãe, indicando uma maior sensibilização contra os antígenos da população humana.

Por exemplo, caso uma receptora tenha um $P R A$ muito grande, isso pode ser explicado por um grande número de gestações pois em cada gestação, a mãe produz anticorpos contra os antígenos do pai, presentes no filho.

\subsubsection{Distância entre Doador e Receptor}

De modo a aumentar as chances de sucesso do transplante, esse deve ser efetuado o mais breve possível a partir da retirada do órgão do doador. Antes de descreverse o significado de o mais breve possivel, três termos necessitam ser definidos:

- Tempo de isquemia ${ }^{1}$ total: compreende o intervalo de tempo entre o momento quando a circulação do sangue pelo rim é interrompida no doador até a completa anastomose ${ }^{2}$ no receptor;

- Tempo de isquemia quente: periodo de quando a circulação de sangue no doador cessa até a introdução do rim em solução preservativa resfriada e

- Tempo de isquemia fria: é a duração da preservação do rim em solução resfriada.

O tempo de isquemia quente tem um importante relacionamento com a sobrevivência do rim transplantado. Se esse período excede 60 minutos, as chances

\footnotetext{
${ }^{1}$ Supressão da circulação sangǘnea em determinada parte do organismo.

${ }^{2}$ Comunicação entre dois vasos sangüíneos.
} 
de funcionamento do rim transplantado são reduzidas seriamente. A duração do tempo de isquemia fria não é tão crítico. $O$ subseqũente funcionamento do órgão não é alterado até 48 horas de preservação [Opelz 88].

O controle sobre o tempo de isquemia quente está fora do escopo do sistema proposto neste trabalho. Contudo, o tempo de isquemia fria, não considerado durante o desenvolvimento do sistema TX3, pode ser minimizado pelo sistema $\mathcal{O R I O N}$ considerando-se a distância - e, conseqüentemente, o tempo de transporte - entre órgão e receptor até o Centro de Transplante mais próximo.

\subsection{Fatores Terciários}

Os fatores terciários são aqueles ligados a consideraçóes humanas ou que atuam como um ponto de referência para os especialistas da área médica. Geralmente, alguns desses fatores são considerados quando existem vários receptores em condições semelhantes para receber um transplante, facilitando a decisão dos médicos.

Os fatores terciários,

- Tempo de Hemodiálise;

- Urgência Médica;

- Idade do Receptor e

- Tempo de Espera do Receptor por um Órgão

são descritos a seguir.

\subsubsection{Tempo de Hemodiálise}

A influência do tempo de hemodiálise, ou duração do tratamento dialítico, no transplante renal pode ser assim descrita: geralmente, uma pessoa que faz hemodiálise precisa receber sangue - devido à perda de sangue ocorrida durante a hemodiálise ou pelo fato de uma parte do sangue ficar no aparelho - fazendo com que o receptor entre em contato com antígenos de várias pessoas, aumentando assim seu número de anticorpos. Dessa forma, é maior a probabilidade de um receptor com muito tempo de hemodiálise apresentar um PRA - Seção 5.4.3 maior que um receptor com um menor tempo de hemodiálise. 


\subsubsection{Urgência Médica}

Cada paciente é classificado com um número descrito pelo sinal de adição $(+)$, número esse que varia de um a cinco, ou seja,

$$
+,++,++,++++,++++
$$

dependendo do grau de urgência médica. Tal classificação é realizada pelos especialistas médicos do sistema SPIT, de acordo com o estado de saúde da cada receptor. Quanto maior o número de + , maior é a urgência médica, ou seja, ao receptor é alocada uma maior prioridade para receber um órgão. Esse fator foi introduzido com o intuito de reduzir o tempo de espera por um órgão por pacientes em estado crítico de saúde. Ele não é considerado pelo sistema TX3 mas sim pela aplicação $\mathcal{O} \mathcal{R} \mathcal{I} \mathcal{N}$.

\subsubsection{Idade do Receptor}

O receptor deve ter uma idade situada em um intervalo pré-definido para que possa ser selecionado para transplante. Atualmente, esse intervalo varia entre 5 até 60 anos completos mas pode ser alterado por decisão da Coordenadoria Central. $\mathrm{O}$ transplante é mais aplicável a pacientes após a puberdade até a idade de 35 a 40 anos devido aos melhores resultados obtidos [Gabriel 85].

Além desse fato, quando o doador é pediátrico, o sistema SPIT considera conveniente que o receptor também seja pediátrico, uma vez que o tamanho do rim adulto é diferente do rim de criançcas.

Devido ao caráter dinâmico da área de transplantes renais e diferindo do sistema TX3, ORION permite alterar o intervalo de idades de forma a adequar-se aos critérios definidos pela Coordenadoria Central.

\subsubsection{Tempo de Espera do Receptor por um Órgão}

No sistema SPIT, um receptor com muito tempo de espera por um órgão tem prioridade sobre outro receptor com pouco tempo de espera no processo de alocação de rins. $O$ tempo de espera é calculado a partir da data de cadastro do paciente no sistema SPIT. 
Esse fator foi introduzido no sistema SPIT devido ao fato que alguns haplótipos HLA são mais comuns que outros. Caso isso nao fosse considerado, muitos receptores poderiam esperar indefinidamente para receber um transplante [Gilks 91].

\subsection{Considerações Finais}

Para que um transplante possa ser efetuado com maior probabilidade de sucesso, vários fatores são relevantes ao sistema SPIT. Neste capítulo esses fatores foram agrupados conforme seu grau de influência na sobrevivência do par receptor-rim transplantado. Isso possibilitou uma primeira etapa na estruturação do conhecimento do sistema $\mathcal{O} \mathcal{R} \mathcal{I O N}$. A seguir, uma descrição detalhada de cada fator foi fornecida, mostrando algumas das extensões do sistema $O R I O N$ em relação ao sistema TX3.

$\mathrm{Na}$ realização do processo de alocação, alguns fatores são claramente mais importantes que outros. Como essa tarefa é realizada pelo Sistema Baseado em Conhecimento existente em $\mathcal{O R I O N}$, o capítulo seguinte é destinado à elucidação desse tema.

Após essa explanação, é possível perceber que um Sistema de Base de Dados sozinho não é capaz de manipular todos esses fatores de forma adequada. $O$ fato de considerar-se, em $\mathcal{O R I O N}$, a interação entre um Sistema de Base Dados e um Sistema Baseado em Conhecimento vem, justamente, da necessidade em preencher algumas lacunas que seriam resultantes da utilização exclusiva de apenas um ou outro desses sistemas. 


\section{Capítulo 6}

\section{O Processo de Alocação de Órgãos}

\subsection{Considerações Iniciais}

Com a chegada de um rim, o sistema São Paulo Interior Transplante seleciona, com base nos fatores introduzidos no Capítulo 5, o receptor mais promissor para receber o órgão.

A escolha desse receptor é baseada em um conjunto de regras. Essas regras são fixadas pela Coordenadoria Central com a participação e a aprovação dos centros hospitalares que integram o SPIT. A partir desse momento, todos os transplantes são efetuados em pacientes escolhidos por essas regras. Somente em casos extraordinários, por exemplo quando um paciente se encontra em estado crítico de saúde, podem ocorrer excesões.

Como uma ciência em contínua evolução, a área de transplantes renais constantemente aprimora-se com as experiências adquiridas e pesquisas realizadas. Da mesma forma, as regras definidas pela Coordenadoria Central são alteradas periodicamente - ressaltando que somente com a aprovação dos centros integrantes - de forma a se adequarem ao processo evolucionário dessa ciência.

As seções seguintes têm o objetivo de estruturar as regras de conhecimento atualmente utilizadas pelo SPIT para a seleção de receptores. Além disso, é mostrada a forma com esses regras são transformadas na linguagem de programação Prolog. 


\subsection{Regras para a Alocação de Rins}

Como foi explanado anteriomente, o sistema $O R \mathcal{I O N}$ tem como objetivo ampliar o sistema TX3 atualmente utilizado. Nas seções seguintes são descritas - de acordo com os fatores explicados na Seção 5.2, página 37 - as regras utilizadas pelo sistema $\mathcal{O} \mathcal{R} \mathcal{I} \mathcal{N}$.

Deve ficar claro que, em todas a regras onde são atribuidos pontos, eles podem ser alterados por outros valores. Como o sistema $\mathcal{O R I O N}$ considera mais fatores do que o sistema SPIT atualmente utiliza, alguns dos valores aqui mencionados são fictícios. Todavia, nada impede que, no futuro, o sistema SPIT os utilize ou que estudantes e pesquisadores os alterem para testar hipóteses. Os valores fictícios utilizados são colocados entre os símbolos $\lceil\mathbf{e}\rceil$.

\subsection{Fatores Primários}

Como ressaltado anteriormente, os fatores primários:

- Grupo $A B O$;

- Cross-Match e

- $H L A$.

resultam na rejeição do transplante imediatamente ou a curto prazo após a cirurgia, caso não sejam satisfeitos. As regras referentes a esses fatores são descritas a seguir.

\subsubsection{Grupo $A B O$}

As regras referentes ao Grupo Sangüíneo são:

SE o grupo sangüíneo do receptor é incompativel com do doador

ENTÃO o receptor não pode receber o transplante.

SE $\quad$ grupo sangüíneo do receptor é igual ao do doador $\mathrm{E}$ o critério de seleção $A B O$ é COMPATIBILIDADE

ENTÃo o receptor recebe $\lceil 1\rceil$ ponto. 
SE $\quad$ grupo sangüíneo do receptor é igual ao do doador $\mathbf{E}$

o critério de seleção $A B O$ é IGUALDADE

ENTÃO o receptor recebe $\lceil 1\rceil$ ponto.

SE o grupo sangüineo do receptor é compativel com do doador E

o critério de seleção $A B O$ é IGUALDADE

ENTÃO o receptor não pode receber o transplante.

SE o grupo sangüíneo do receptor é compatível com do doador E

- critério de seleção $A B O$ é COMPATIBILIDADE

ENTÃO o receptor recebe $[0]$ pontos.

Como uma extensão do sistema TX3, é possível considerar o Fator $R h$ durante a escolha de receptores.

SE o Fator $R h$ do receptor é idêntico ao $R h$ do doador

ENTÃO o receptor recebe $\lceil 1\rceil$ ponto.

SE o Fator $R h$ do receptor é diferente do $R h$ do doador

ENTÃO o receptor recebe $[0\rceil$ pontos.

\subsubsection{Cross-Match}

Como esse exame é realizado após a seleção dos receptores mais promissores a um determinado rim, existe apenas a restrição que o soro do receptor, que será utilizado para realizar o exame de Cross-Match, esteja dentro do prazo de validade, ou seja:

SE $\quad$ soro do receptor foi coletado há mais de 90 dias

ENTÃo o receptor não pode ser selecionado para transplante.

\subsection{3 $\quad H L A$}

Para o sistema $H L A$ é adotado o critério de pontuação mostrado a seguir. Dependendo do número de haplótipos incompativeis em relação ao doador, o receptor recebe uma pontuação diferente.

SE o receptor pertencer hospital diferente do doador

ENTÃo são necessárias 6 compatibilidades nos loci $H L A$ 
SE o receptor for retransplantado

ENTÃO são necessárias 2 compatibilidade nos loci $H L A-D R \mathrm{e}$ 2 compatibilidades nos loci $H L A-B$

SE o número de diferenças entre os loci doador-receptor $H L A-A$ for igual a $0 \mathrm{E}$ $H L A-B$ for igual a $0 \mathrm{E}$ $H L A-D R$ for igual a 0

ENTÃO o receptor recebe 10 pontos

SE o número de diferenças entre os loci doador-receptor $H L A-A$ for igual a 0,1 ou $2 \mathrm{E}$ $H L A-B$ for igual a $0 \mathrm{E}$ $H L A-D R$ for igual a 0

ENTÃO o receptor recebe 7 pontos

SE o número de diferenças entre os loci doador-receptor $H L A-A$ for igual a $0 \mathrm{E}$ $H L A-B$ for igual a $0 \mathrm{E}$ $H L A-D R$ for igual a 0,1 ou 2

ENTÃD o receptor recebe 6 pontos

SE o número de diferenças entre os loci doador-receptor $H L A-A$ for igual a $0 \mathrm{E}$ $H L A-B$ for igual a $1 \mathrm{E}$ $H L A-D R$ for igual a 0

ENTÃO O receptor recebe 3 pontos

SE o número de diferenças entre os loci doador-receptor $H L A-A$ for igual a $0 \mathrm{E}$ $H L A-B$ for igual a $0 \mathrm{E}$ $H L A-D R$ for igual a 1

ENTÃO o receptor recebe 3 pontos

SE o número de diferenças entre os loci doador-receptor $H L A-A$ for igual a $O \mathrm{E}$ $H L A-B$ for igual a $2 \mathrm{E}$ $H L A-D R$ for igual a 0

ENTÃO O receptor recebe 2 pontos 
SE o número de diferenças entre os loci doador-receptor $H L A-A$ for igual a $0 \mathrm{E}$ $H L A-B$ for igual a $0 \mathrm{E}$ $H L A-D R$ for igual a 2

ENTÃo o receptor recebe 2 pontos

SE o número de diferenças entre os loci doador-receptor $H L A-A$ for igual a $0 \mathrm{E}$ $H L A-B$ for igual a $1 \mathrm{E}$ $H L A-D R$ for igual a 1

ENTÃO O receptor recebe 2 pontos

SE o número de diferenças entre os loci doador-receptor $H L A-A$ for igual a $0 \mathrm{E}$ $H L A-B$ for igual a $2 \mathrm{E}$ $H L A-D R$ for igual a 1

ENTÃO o receptor recebe 1 ponto

SE o número de diferenças entre os loci doador-receptor $H L A-A$ for igual a $0 \mathrm{E}$ $H L A-B$ for igual a $1 \mathrm{E}$ $H L A-D R$ for igual a 2

ENTÃD o receptor recebe 1 ponto

SE o número de diferenças entre os loci doador-receptor não estiver definido pelas regras anteriores

ENTÃO o receptor recebe 0 pontos

\subsection{Fatores Secundários}

De acordo com a Seção 5.4, os fatores secundários

- Transfusões;

- Retransplantes;

- Painel;

- Gestações e

- Distância entre Doador e Receptor 
são aqueles que, caso satisfeitos, aumentam as chances de sucesso do transplante a médio ou a longo prazo. Uma descrição da influência deles no processo de seleção de rins é fornecida a seguir.

\subsubsection{Transfusões}

SE O número de transfusões de um receptor estiver entre 0 e 2

ENTÃO o receptor recebe $\lceil 0\rceil$ pontos

SE $\quad$ número de transfusões de um receptor estiver entre 3 e 5

ENTÃO o receptor recebe $\lceil 1\rceil$ ponto

SE O número de transfusões de um receptor for maior que 5

ENTÃO o receptor recebe $\lceil 2\rceil$ pontos

$\mathrm{Na}$ realidade, essas regras foram implementadas através de uma única regra que verifica, numa tabela, em qual intervalo o número de transfusões se situa. Para cada intervalo, existe uma pontuação associada. Assim, é fácil modificar tanto os intervalos utilizados como suas respectivas pontuações.

\subsubsection{Retransplantes}

SE o número de retransplantes de um receptor estiver entre 0 e 1

ENTÃO o receptor recebe $[0]$ pontos

SE o número de retransplantes de um receptor estiver entre 1 e 2

ENTÃO o receptor recebe $\lceil 1\rceil$ ponto

SE o número de retransplantes de um receptor for major que 2

ENTÃO o receptor recebe $\lceil 2\rceil$ pontos

Da mesma forma utilizada com o número de transfusões, essas três regras foram combinadas numa única que verifica uma tabela de pontos.

\subsubsection{Painel}

SE $\quad$ receptor possui um $\mathrm{PRA} \geq 80 \%$

ENTÃo recebe 4 pontos. 
SE $\quad$ o receptor possui um PRA $<80 \%$

ENTÃo não recebe pontos.

\subsubsection{Gestaçōes}

SE $\quad$ número de gestações de uma receptora estiver entre 0 e 1

ENTÃo ela recebe $[0\rceil$ pontos

SE o número de gestações de uma receptora for major que 2

ENTÃo ela recebe $\lceil 1\rceil$ ponto

Considerações análogas às regras referentes aos fatores Transfusões e Retransplantes são válidas para o número de gestações.

\subsubsection{Distância entre Doador e Receptor}

SE a distância entre o doador e um receptor até o centro de transplante mais próximo deles seja tal que exceda o tempo crítico de conservação do rim em solução resfriada

ENTÃo o transplante não pode ser efetuado.

\subsection{Fatores Terciários}

Os fatores terciários são aqueles relacionados com considerações humanas ou que atuam como um ponto de referência para os especialistas médicos, a saber:

- Tempo de Hemodiálise;

- Urgência Médica;

- Idade do Receptor e

- Tempo de Espera do Receptor por um Órgão.

Em seqüência, seguem-se suas regras respectivas. 


\subsubsection{Tempo de Hemodiálise}

SE o tempo de hemodiálise de um receptor estiver entre 0 e 1 ano

ENTÃo o receptor recebe $\lceil 0\rceil$ pontos

SE o tempo de bemodiálise de um receptor for major que 1 ano

ENTÃo o receptor recebe $\lceil 1\rceil$ ponto

As observações descritas para Transfusões também são válidas para esse fator.

\subsubsection{Urgência Médica}

SE um receptor não possui urgência médica

ENTÃO ele recebe $[0]$ pontos

SE um receptor possui urgência médica igual a " $t^{\text {" }}$

ENTÃO ele recebe $\lceil 1\rceil$ ponto

SE um receptor possui urgência médica igual a " $+t^{\text {" }}$

ENTÃo ele recebe [2] pontos

SE um receptor possui urgência médica igual a " $+t+$ "

ENTÃO ele recebe [3] pontos

SE um receptor possui urgência médica igual a " ++++ "

ENTÃO ele recebe [4] pontos

SE um receptor possui urgência médica igual a " $+++++^{\text {" }}$

ENTÃo ele recebe [5] pontos

\subsubsection{Idade do Receptor}

SE doador tem entre 0 e 11 anos

ENTÃo o receptor deve ter entre 0 e 11 anos

SE doador tem mais de 11 anos

ENTÃo o receptor pode ter qualquer idade 


\subsubsection{Tempo de Espera do Receptor por um Órgão}

SE O receptor está cadastrado entre 0 meses e 1 ano incompleto

ENTÃo ele não recebe pontos.

SE o receptor está cadastrado há mais de 1 ano

ENTÃo ele recebe 0,5 pontos por ano.

\subsection{Estrutura das Regras em Prolog}

Com base nas informações descritas nas seções anteriores, é possível transformar as regras - utilizadas no processo de alocação de rins - em Prolog [Arity 90, Monard 89c]. Dessa forma, nos parágrafos seguintes é suposto um prévio conhecimento dessa linguagem de programação. O leitor não familiarizado com Prolog pode deixar de ler o restante desta seção.

O agrupamento dos fatores em 3 categorias de acordo com o grau de influência no resultado do transplante - Seção 5.2 - permite definir a forma básica de funcionamento do sistema $\mathcal{O} \mathcal{L} \mathcal{I} \mathcal{N}$ : para encontrar o(s) receptor(es) mais promissor(es) para um rim, o Sistema Baseado em Conhecimento procede da seguinte forma:

Dado um doador específico, para cada receptor:

1. calcular o número de pontos para seus fatores primários;

2. calcular o número de pontos para seus fatores secundários;

3. calcular o número de pontos para seus fatores terciários e

4. combinar os pontos dos fatores primários, secundários, e terciários para obter o número de pontos do receptor.

Isso pode ser transformando para Prolog da seguinte maneira: para cada par doador-receptor $\langle D, R\rangle$ na Base de Dados determinística do Sistema Baseado em Conhecimento de $O R I O N$ é ativada a regra

$$
\text { O_recomenda }(D, R, P)
$$

onde $\mathrm{P}$ é o número de pontos que o receptor receberá no final do processo de alocação. Essa regra inicial é mostrada a seguir. 


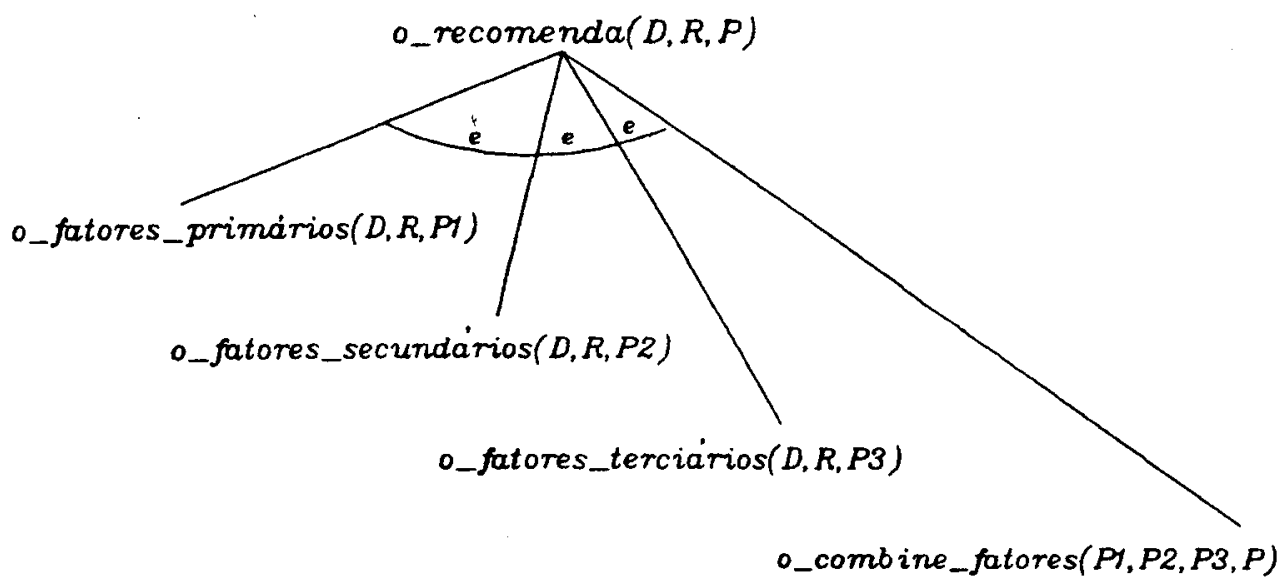

Figura 6.1: Regra Inicial do Processo de Alocação.

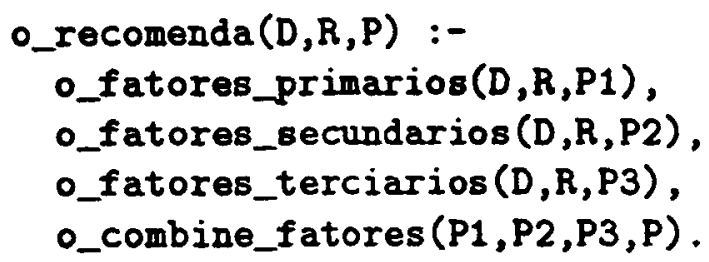

Uma visualização gráfica pode ser observada na Figura 6.1. As variáveis $\mathrm{P} 1$, P2 e P3 correspondem aos pontos dos fatores primários, secundários e terciários, respectivamente.

Pode-se perceber que essa estrutura é interessante para a seleção de receptores pois, como o raciocínio utilizado pelo Sistema de Base de Dados é Regressivo e devido às características do Núcleo do SBC utilizado [Rodrigues 90a] ${ }^{1}$, se a subregra 0_fatores_primarios (D, R, P1) não for bem sucedida, ela falha e o sistema não tenta provar as sub-regras seguintes.

Como uma ampliação, os $P_{i}$ 's são ponderados por valores que podem ser facilmente trocados para todas as regras. Além disso, as combinações de pontos

\footnotetext{
${ }^{1}$ Explicações mais detalhadas sobre o Núcleo do SBC e o uso de Raciocinio Regressivo no sistema ORION são fornecidas no Capítulo 7.
} 


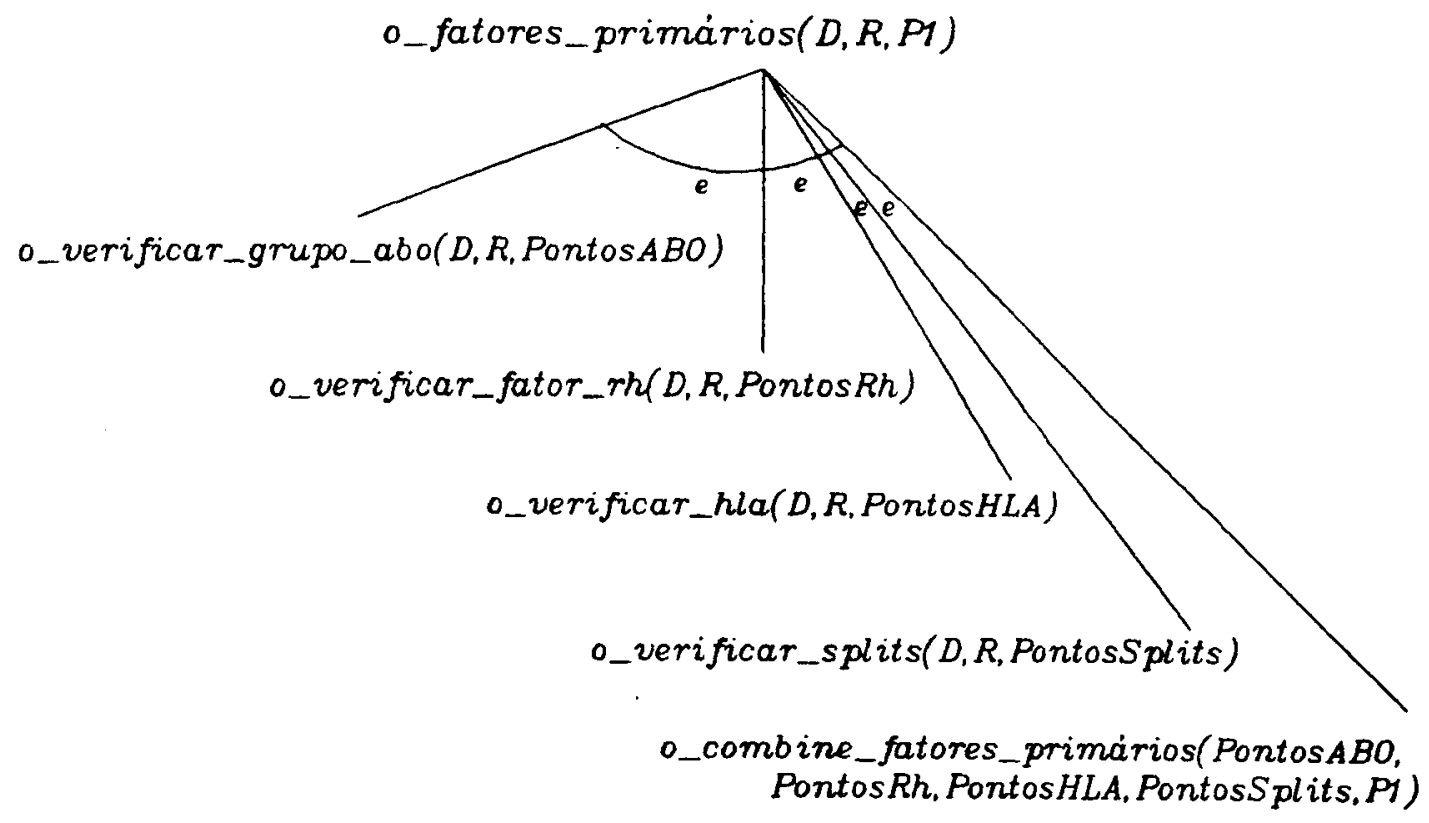

Figura 6.2: Regra para os Fatores Primários.

podem também ser alteradas de forma bem simples. Com isso, é possivel alterar a forma de cálculo dos pontos de receptores alterando apenas as regras que realizam a combinação.

Ao tentar provar a regra o_recomenda $(D, R, P)$, o sistema tenta primeiramente provar a regra o_fatores_primarios(D,R,P1). Essa última regra - graficamente representada na Figura 6.2 - por sua vez, possui sub-regras a serem provadas:

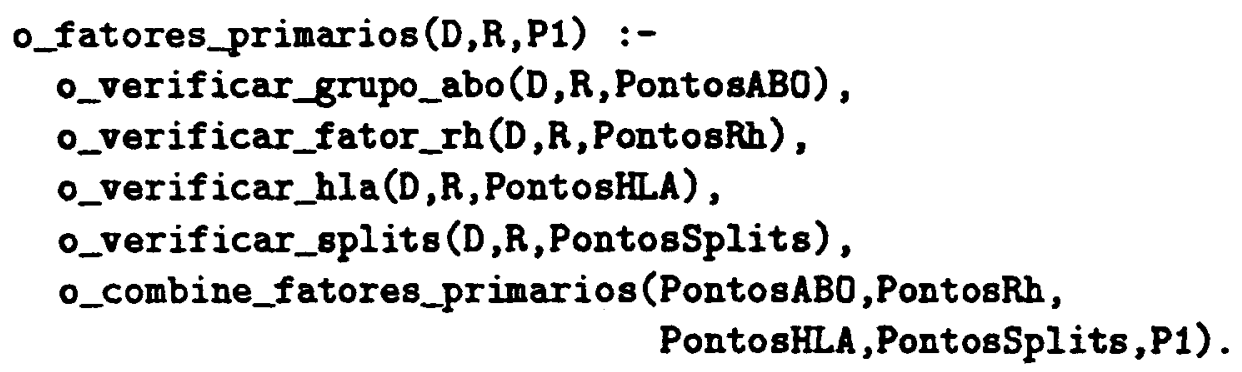

Observa-se a estrutura similar daquela mostrada na Figura 6.1: os fatores são examinados e no final seus pontos são combinados. Esse comportamento também pode ser observado com os demais fatores. 
Para provar a regra o_fatores_primarios $(D, R, P 1), \mathcal{O R I O N}$ tenta verificar a regra o_verificar_grupo_abo (D, R, PontosABO). Essa regra, então, calcula a quantidade de pontos conforme descreve a Seção 6.3.1. Sendo essa regra bem sucedida, o Sistema Baseado em Conhecimento tentará provar a próxima regra, o_verificar_rh ( $D, R$, PontosRh), de forma análoga. Caso todas as regras referentes aos fatores primários sejam bem sucedidas, é efetuada a combinação dos pontos desses fatores, obtendo-se P1. Após isso, o sistema tentará provar as regras dos fatores secundários, terciários e, finalmente, combinar os pontos obtidos nos três grupos de fatores para o receptor em questão.

Após encontrar o número de pontos para todos os receptores, $\mathcal{O R I O N}$ os classifica em ordem decrescente de pontos. Com isso, é gerado um relatório classificado dos receptores mais promissores para aquele doador específico.

Se necessário - no caso de igualdade na pontuação entre receptores - o sistema $\mathcal{O R I O N}$ automaticamente tenta desempatá-los. Isso é obtido através da definição, pelo usuário, de fatores - dentre os fatores primários, secundários e terciários - de desempate.

Por exemplo, suponha que Transfusões e Retransplantes sejam definidos como fatores de desempate. Se, ao final de um processo de alocação, quatro receptores estiverem com a mesma pontuação, $\mathcal{O R I O N}$ verificará a pontuação de cada um referente ao fator Transfusões, ordenando-os de acordo com os pontos obtidos nesse fator. Supondo que, após esse processo, dois receptores continuem empatados, então o fator Retransplantes será utilizado para tentar o desempate entre esses dois indivíduos.

\subsection{Considerações Finais}

Com base nas informações descritas no Capítulo 5 foi possível descrever as regras referentes aos fatores primários, secundários e terciários. Adicionalmente, foi mostrado como as regras foram traduzidas para a linguagem de programação lógica Prolog. Durante esse processo, ficou claro que o agrupamento dos fatores facilitou a estruturação das regras de conhecimento utilizadas em $O R I O N$.

Com o intuito de facilitar a compreensão das regras de conhecimento, descrições sucintas sobre a forma do raciocínio do Sistema Baseado em Conhecimento e de seu funcionamento foram fornecidas. No capítulo seguinte, entretanto, essas e outras características do sistema $O R I O N$ serão melhor explicadas. 


\section{Capítulo 7}

\section{O Sistema $\mathcal{O R I O N}$}

\subsection{Considerações Iniciais}

Neste capítulo é descrito o funcionamento e o tipo de interação entre o Sistema de Base de Dados e o Sistema Baseado em Conhecimento utilizados no sistema $\mathcal{O R I O N}$. São também justificados os motivos pelos quais foi escolhido um tipo específico de interação e mostrado o tipo de "raciocínio" utilizado pelo SBC. São descritos, por último, os ambientes de desenvolvimento utilizados para o SBD e o SBC.

\subsection{Funcionamento}

Das várias maneiras que um SBC pode interagir com um SBD, o sistema $O R I O \mathcal{N}$ utiliza aquela denominada "Comunicação Intersistemas", página 27, com abordagem "Processamento e Controle Distribuidos", como pode ser observada na Figura 7.1. A decisão de utilizar esse tipo de interação será melhor entendida após as explicações dadas a seguir.

A idéia geral da arquitetura de $O R I O \mathcal{N}$ é a seguinte: todas as alterações, cadastros, consultas, etc de receptores, doadores ou hospitais são efetuadas com acesso direto ao Sistema de Base de Dados, tais como:

- Cadastrar um receptor;

- Suspender um receptor por algum motivo; 


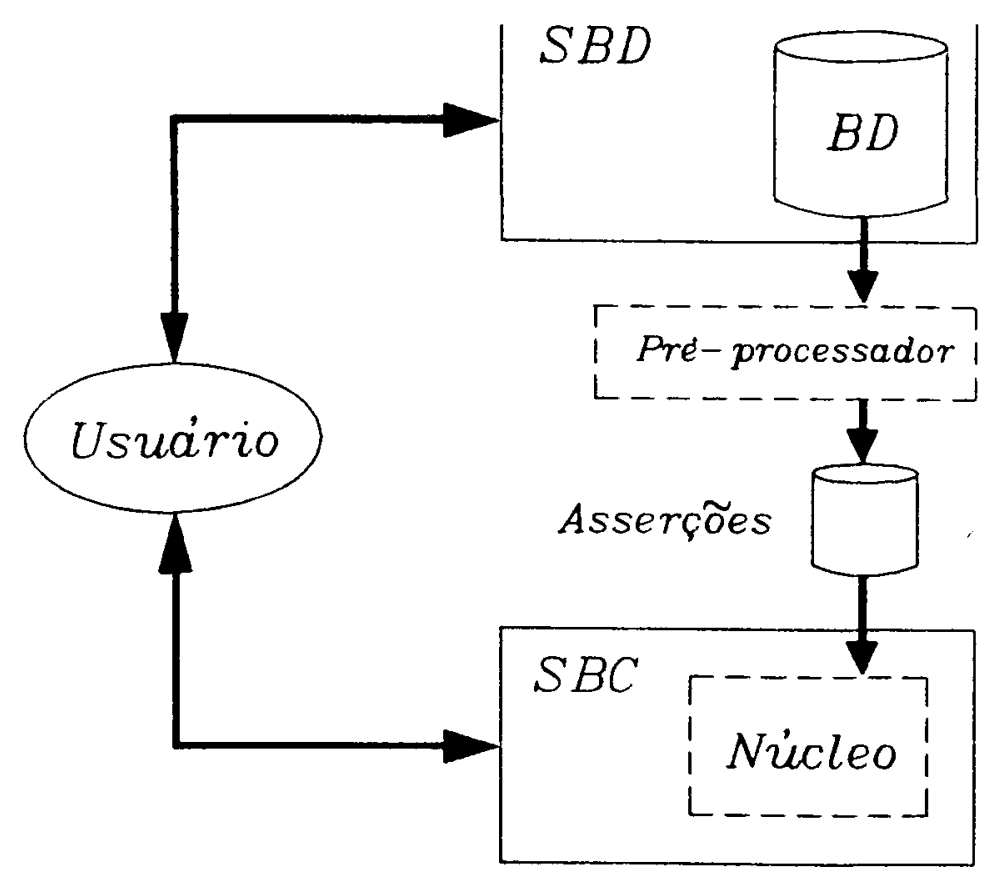

Figura 7.1: $O$ Sistema $O$ RION.

- Verificar as informações de um determinado hospital, etc...

bem como relatórios do tipo:

- Pacientes com soro fora do prazo de validade;

- Hospitais suspensos do processo de alocação de órgãos;

- Relação dos pacientes já transplantados...

Como alguns critérios utilizados no processo de alocação de órgãos podem ser alterados, por exemplo:

- Faixa de idade do receptor;

- Número mínimo de transfusões;

- Número mínimo de compatibilidades $H L A$ entre doador e receptor;

- Compatibilidade ou igualdade no grupo $A B O$ do doador com o receptor, etc... 
é possível para a equipe médica, se for de interesse, restringir ou relaxar esses critérios da forma que achar conveniente. Isso é muito importante, pois os especialistas podem restringir esses critérios e, dessa forma, podem selecionar os receptores mais "promissores" para um determinado rim. Geralmente, restringindo os critérios o número de receptores a serem selecionados tende a diminuir.

Deve ficar claro que, no SPIT, somente a Coordenadoria Central pode alterar esses critérios, com a aprovação dos hospitais integrantes. Assim, em seleções reais de receptores, esses critérios são sempre os mesmos até que o sistema São Paulo Interios Transplante, com seus centros hospitalares integrantes, decida alterálos. As facilidades de alteração dos critérios de seleção foram introduzidas, em $\mathcal{O} \mathcal{I O N}$, principalmente para atividades de ensino e pesquisa ${ }^{1}$.

Quando um doador estiver disponivel, suas caracteristicas relevantes são informadas ao Sistema de Base de Dados. De posse dessa informação e com base nesses critérios variáveis, um processo do SBD é ativado para fornecer os possiveis receptores para o doador específico, utilizando a informação determinística sobre os receptores contida nele, a saber:

- Grupo Sangüíneo;

- $H L A$;

- Painel;

- Número de retransplantes;

- Data do soro mais recente, etc...

Antes da ativação do Sistema Baseado em Conhecimento, todo subconjunto dos receptores factíveis - juntamente com informações específicas relacionadas a eles e ao doador - é transformado, pelo pré-processador - Figura 7.1 - em asserções no formato entendido pelo SBC e gravados na Base de Dados desse sistema.

Deve ser ressaltado que o processo de interagir com o SBD para em seguida iniciar a execução do Sistema Baseado em Conhecimento pode ser repetido tantas vezes quantas o estudante, ou pesquisador, julgar necessárias. Desse modo, é fácil alterar algum critério do processo de alocação e obter os receptores que se ajustam a essas novas considerações, possibilitando ao usuário uma noção quantitativa da população selecionada.

\footnotetext{
${ }^{1}$ Embora a alteração desses critérios seja fácil de ser efetuada, ORION possui um esquema de segurança. Maiores detalhes são fornecidos na Seção 8.2.
} 
É importante notar que, nessa fase, o máximo de dez pacientes selecionados para o exame Cross-Match não é uma restrição. A idéia é que o Sistema Baseado em Conhecimento trabalhe com todos os receptores que possuem chances de receber os rins do doador em questão.

O SBC, em princípio, seleciona todos os receptores e fornece uma listagem em ordem de preferência. A quantidade de pacientes que realizará o exame de CrossMatch pode ser, eventualmente, restringida. Ou seja, o SBC efetua seu trabalho, independentemente do número de receptores que serão selecionados para o CrossMatch.

Uma facilidade incorporada ao SBC do sistema $O R I O N$ é a capacidade de habilitar ou desabilitar cada fator que pode ser considerado no processo de alocação. Isso proporciona ao usuário a faculdade de ignorar alguns fatores durante esse processo a fim de testar suas hipóteses. É claro que, em processos reais de alocação de rins, os fatores habilitados são definidos e somente são alterados pela Coordenadoria Central com a aprovação dos centros hospitalares integrantes.

Salienta-se que a forma de proceder descrita acima é distinta daquela do préprocessador. No primeiro caso, o SBC utiliza apenas os fatores habilitados para selecionar os receptores - dentre todos os receptores factiveis. $\mathrm{O}$ préprocessador tem a função de filtrar, converter e transferir as informações dos receptores factiveis - rejeitando receptores sem chances de receberem o rim em questão - do Sistema de Base de Dados para o Sistema Baseado em Conhecimento.

Durante a execução do SBC, ele pode necessitar informações adicionais além daquelas que foram passadas a ele pelo pré-processador. Nesse caso, ele requisita esses dados ao usuário. Ao usuário é dada a capacidade de perguntar quais os motivos que levaram o sistema a concluir algo, por quê uma pergunta foi efetuada, etc. Ao término da operação, as informações deduzidas pelo SBC com base nas características do doador e receptor utilizados são apagadas.

Essa forma de "esquecimento" do Sistema Baseado em Conhecimento permite que $O R I O N$ seja utilizado em testes por estudantes. Um doador imaginário pode ser introduzido no SBD e logo após ativado o pré-processador. Isso criará as asserções para o Sistema Baseado em Conhecimento, que é então ativado. A partir desse ponto, os estudantes podem formular e testar algumas hipóteses como se o doador realmente existisse. Ao sair do sistema, os dados do doador hipotético são automaticamente apagados, não influenciando em processos de alocação reais que sejam realizados posteriormente.

Quando o usuário, auxiliado pelo Sistema Baseado em Conhecimento, decidir 
quais os receptores que receberão os órgãos e efetuado o transplante, esse fato é notificado ao sistema entrando os dados pelo SBD. A atualização não é efetuada automaticamente por $\mathcal{O R I O N}$ logo após a seleção, pois é possível que os receptores não sejam encontrados ou ocorra outro imprevisto qualquer. Somente após a realização da cirurgia é que esse fato será notificado ao Sistema de Base de Dados.

Com essas explicações, pode-se notar que a solução de interação entre o SBD e - SBC adotada é possível devido ao fato da Base de Dados de pacientes aptos a receber transplante possuir, atualmente, cerca de mil registros; além disso, dificilmente todos os registros serão transformados em asserções para o Sistema Baseado em Conhecimento, pois o pré-processador atua como um filtro.

Outro ponto importante é que caso se deseje utilizar outro software para a implementação do SBD, somente ele e o pré-processador devem ser alterados. Não será necessária nenhuma modificação no SBC. No caso da utilização de outro software que implemente o $\mathrm{SBC}$, só ele necessita ser reescrito.

Além do que foi dito, o interessante em não ter acesso direto ao Sistema de Base de Dados é que o espaço de busca é adequadamente reduzido para o Sistema Baseado em Conhecimento - que é a parte responsável em fazer muitas inferências - pois ele somente trabalha com pacientes que têm chances de ser transplantados.

A forma de proceder do SBC descrita acima indica que a utilização de Raciocínio Regressivo - "Backward Chaining" - é apropriada, pois além dos pacientes que tem-se da primeira filtragem, o Sistema Baseado em Conhecimento precisará de algumas informaçóes adicionais para ser auxiliado nas suas decisões, ou seja, no referenciamento do conhecimento determinístico existente na Base de Dados nele contida. Utilizando Raciocínio Regressivo, essas informações adicionais são requisitadas ao usuário somente quando necessárias.

Além desse fato, a utilização de Raciocínio Regressivo permite que o SBC descarte tão logo quanto possível os receptores que não obederem a um determinado critério. Com isso, inferências não proveitosas são descartadas o mais cedo possivel, poupando tempo de computação.

Conforme descrito na Seção 3.2.3, página 29, com o tipo de interação adotado poderiam ocorrer situações de inconsistência, incompatibilidade e redundância de informação. Entretanto, deve ser salientado que, em $\mathcal{O R I O N}$, as duas primeiros situações não ocorrem e a última ocorre em escala mínima.

A inconsistência entre a informação existente no Sistema de Base de Dados e aquela no Sistema Baseado em Conhecimento é eliminada uma vez que o SBC é 
ativado sempre no final de um processo de seleção, ou seja, imediatamente após o término da execução do pré-processador.

A incompatibilidade é evitada pela existência do pré-processador. Ele é o único processo encarregado de transformar as informações do formato do SBD para o SBC. Além disso, é interessante notar que existe uma diferença entre as Figuras 7.1, página 66 e 3.6, página 28: o fluxo de informação na Figura 7.1 é unidirecional, apenas do SBD para o SBC; na Figura 3.6 o fluxo é bidirecional.

A redundância de dados, embora exista, é reduzida ao mínimo. Isso é possivel uma vez que, na passagem de informação do SBD para o SBC, apenas um subconjunto dos receptores - aqueles que possuem condiçóes para receber o transplante é enviado do SBD para o SBC. Todavia, é interessante notar que o subconjunto que é passado do SBD para o SBC pode ser totalmente descartado ao final da operação do Sistema Baseado em Conhecimento.

Assim, quando o Sistema de Base de Dados está sendo executado, não há duplicação de informação. Ao ativar o Sistema Baseado em Conhecimento, o SBD é desativado, após pré-processar as informações necessárias para o SBC. O Sistema Baseado em Conhecimento, por sua vez, lê as informações pré-processadas, executa seu trabalho e devolve o controle para o SBD. Com isso, é possível perceber que a redundância das informações em $O R I O N$ existe apenas durante um curto período de tempo e de forma minimizada.

\subsection{Ambiente de Desenvolvimento do SBD}

O Sistema de Base de Dados foi implementado na linguagem de programação dBase III [Simpson 86], utilizando-se o compilador Clipper Versão 5.01, da Nantucked Corp. para a geração do código executável [Ramalho 91]. Nessa versão do compilador, estão disponiveis um pré-processador e outras inovações que tornam a linguagem mais flexível, com as facilidades de gerenciamento de bases de dados e interface com outras linguagens de programação.

Para o módulo de criptografia de informações dos usuários do sistema (senha, bases de dados modificadas, etc) utilizou-se o compilador Microsoft $C$ versão 4.0 [Kernighan 88]. A criptografia foi efetuada através de cifras de substituição e inserção de chave similar aos algoritmos descritos em [Schildt 87].

Para a elaboração de um dos gráficos, foi utilizado o compilador Borland Turbo Pascal versão 5.5 [Carroll 88]. Com esse compilador foi possível definir o gráfico para diversos tipos de monitor (CGA, EGA, Hercules, etc). 


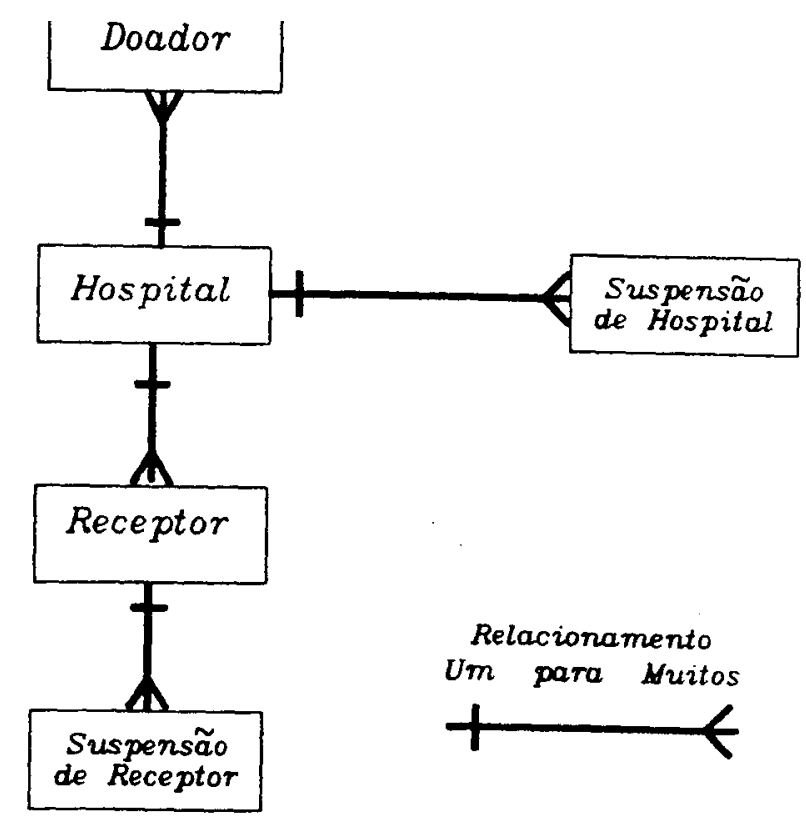

Figura 7.2: Modelo Entidade-Relacionamento de ORION.

A Figura 7.2 mostra o modelo Entidade-Relacionamento de $\mathcal{O R I O N}$ [Chen 76]. Como pode ser observado no relacionamento entre as entidades Receptor e Hospital, um receptor está relacionado com apenas um hospital; um hospital, por sua vez, está relacionado com vários receptores - relacionamento 'Um para Muitos'. Nesse caso, pode-se dizer que um receptor pertence a um único hospital; por outro lado, um hospital possui vários receptores. Os demais relacionamentos nessa figura são análogos ao explicado. Uma descrição majs detalhada do projeto do Sistema de Base de Dados é fornecida no Apêndice B.

\subsection{Ambiente de Desenvolvimento do SBC}

O ponto crucial no desenvolvimento de Sistemas Baseados em Conhecimento corresponde à especificação das regras de conhecimento. É importante ressaltar que para realizar essa tarefa e para casos duvidosos que apresentaram-se no desenvolvimento da Base de Conhecimento, contou-se com o auxílio do especialista no domínio, Prof. Dr. Agenor Ferraz, médico e docente do Hospital das Clínicas da Faculdade de Medicina de Ribeirão Preto - USP.

O ambiente para desenvolvimento de Núcleos de Sistemas Especialistas - elaborado no ICMSC [Monard 91,Rodrigues 90a] - foi utilizado para verificar a validade das regras de conhecimento. Esse sistema foi escrito na linguagem de 


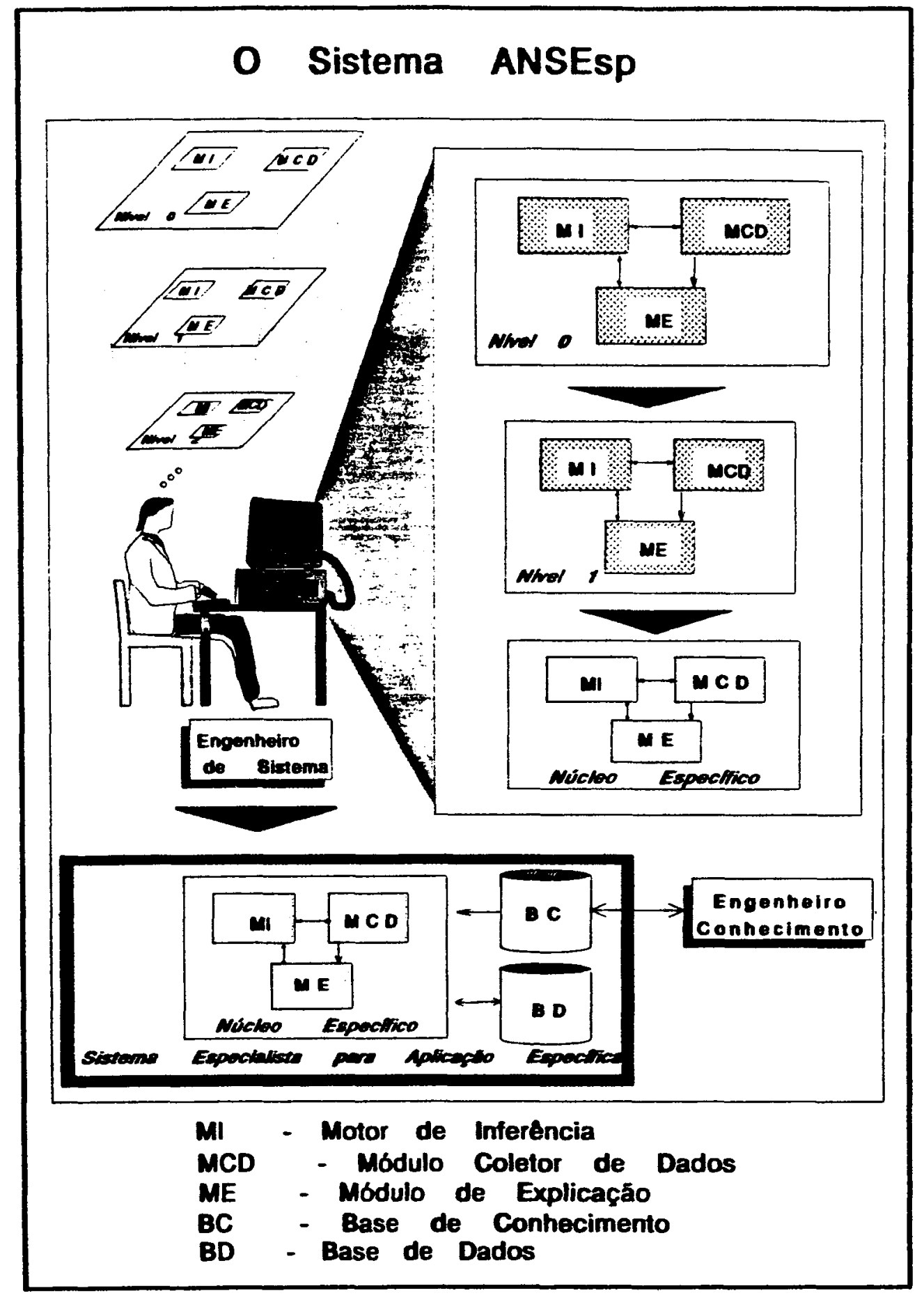

Figura 7.3: Ambiente para Auxiliar a Construção de Núcleos Específicos 
programação lógica Prolog [Arity 90] que utiliza a sintaxe do Prolog de Edinburgh [Bratko 90,Clocksin 87,Sterling 87].

Uma característica importante do ambiente desenvolvido em [Rodrigues 90a] é a facilidade oferecida ao projetista de unir ou alterar os elementos que o compõem, a saber:

- Motor de Inferência, elemento que contém uma linha de raciocínio com incertezas [Monard 89a] e processa o conteúdo das Bases de Dados e Conhecimento [Monard 89b];

- Módulo Coletor de Dados, o qual é responsável pela comunicação com o usuário [Rodrigues 89,Rodrigues 90b];

- Módulo de Explicação, elemento capaz de explicar porque o Motor de Inferência realiza uma determinada pergunta, como chegou a uma conclusão, o que aconteceria se alguma informação fosse trocada...

No nível mais alto tem-se a implementação total do Núcleo de um Sistema Especialista - NSE - incluindo todas as opções implementadas nesse ambiente. Entretanto, como em muitas aplicações a Base de Conhecimento pode não necessitar de todas as opções disponiveis, o projetista pode construir um núcleo específico para a aplicação em questão. Esse núcleo restrito pode ser visto no Nivel 1 da Figura 7.3 [Rodrigues 90a].

O Nível 1 é composto por um subconjunto do Nivel Superior, onde os códigos irrelevantes são removidos, sem nenhuma modificação no código remanescente. Isto constitui uma grande vantagem, pois há uma melhora no tempo de resposta do sistema final, uma vez que o núcleo faz uso de Meta-Interpretadores [Rodrigues 90c].

Como mais uma otimização, este ambiente também permite alterar o NSE para adequá-lo à aplicacãa específica em desenvolvimento, como mostra o Nível $2 \mathrm{da}$ Figura 7.3. Tais modificações permitem, por exemplo, alterar:

- a forma de armazenamento e acesso à Área de Trabalho;

- o modelo utilizado pelo Motor de Inferência para manipular incertezas;

- a estrutura da informação manipulada pelo Módulo de Explicação...

A construção do Nivel 1 está automatizada através do sistema computacional $\mathcal{G E N} \mathcal{E S E}$ [Franco 91,Franco 92]. Não foi necessário gerar o Nível 2 no desenvolvimento deste trabalho. 


\subsection{Consideraçōes Finais}

Dentre as várias formas de interação entre Sistemas de Base de Dados e Sistemas Baseados em Conhecimento, citadas no Capítulo 3, foi escolhida a "Comunicação Intersistemas", com abordagem "Processamento e Controle Distribuídos" para integrar o SBD com o SBC que compóem $\mathcal{O R I O N}$.

Adicionalmente, neste capítulo foi explicada a forma de ação do SBC. Com isso, foi possível determinar que utilização de Raciocínio Regressivo seria apropriada para o Sistema Baseado em Conhecimento em questão.

Finalmente, foram mostradas algumas características dos ambientes utilizados para desenvolver o Sistema de Base de Dados e o Sistema Baseado em Conhecimento, componentes do sistema desenvolvido neste trabalho. 


\section{Capítulo 8}

\section{Exemplos de Funcionamento do Sistema $\mathcal{O R I O N}$}

\subsection{Considerações Iniciais}

Alguns exemplos que mostram a forma de interação entre o usuário e o sistema $\mathcal{O} I O \mathcal{N}$ são apresentados neste capítulo. Isso tern como meta fornecer uma visão geral do funcionamento do sistema. De forma a facilitar o entendimento, é utilizado um conjunto reduzido de dados.

Conforme explicado anteriormente, $\mathcal{O} \mathcal{R} \mathcal{O N}$ é um sistema híbrido. Dessa forma, são apresentados exemplos separados para o Sistema de Base de Dados e para o Sistema Baseado em Conhecimento que compõem a aplicação desenvolvida.

\subsection{O SBD de $\mathcal{O} \mathcal{L I N}$}

No início da execução do sistema $\mathcal{O} I \mathcal{O N}$ é apresentada, ao usuário, a tela mostrada na Figura 8.1. Após o usuário pressionar qualquer tecla, surge a tela exibida na Figura 8.2 responsável pela autenticação do usuário. Nesse momento, é conveniente salientar que, ao pressionar a tecla ESCAPE, interrompe-se qualquer atividade que sistema esteja realizando, inclusive na fase de autenticação. Caso o usuário forneça um par (código, senha) válido, aparece o menu principal, conforme a Figura 8.3, página 77. 


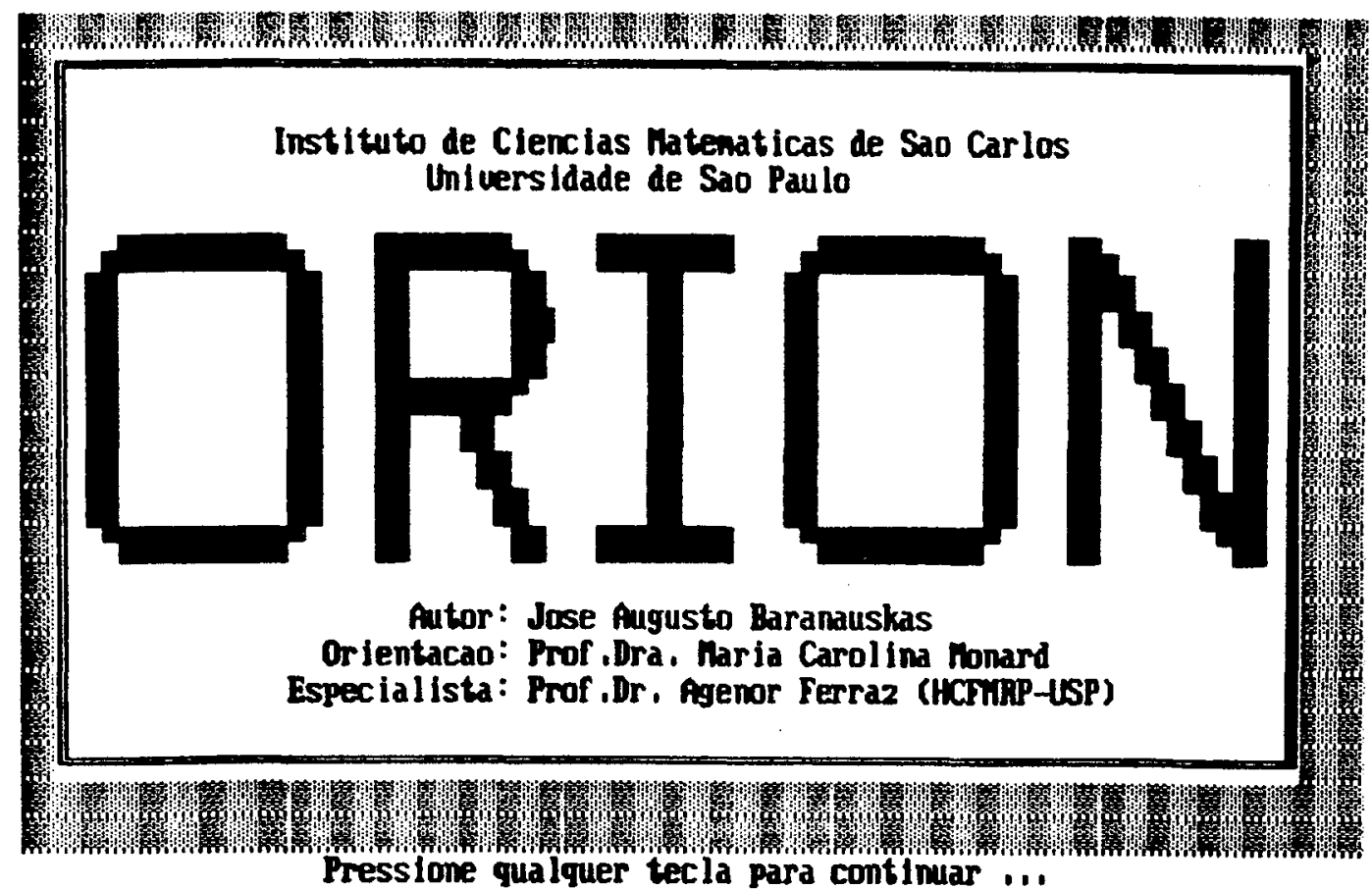

Figura 8.1: Tela de Apresentação

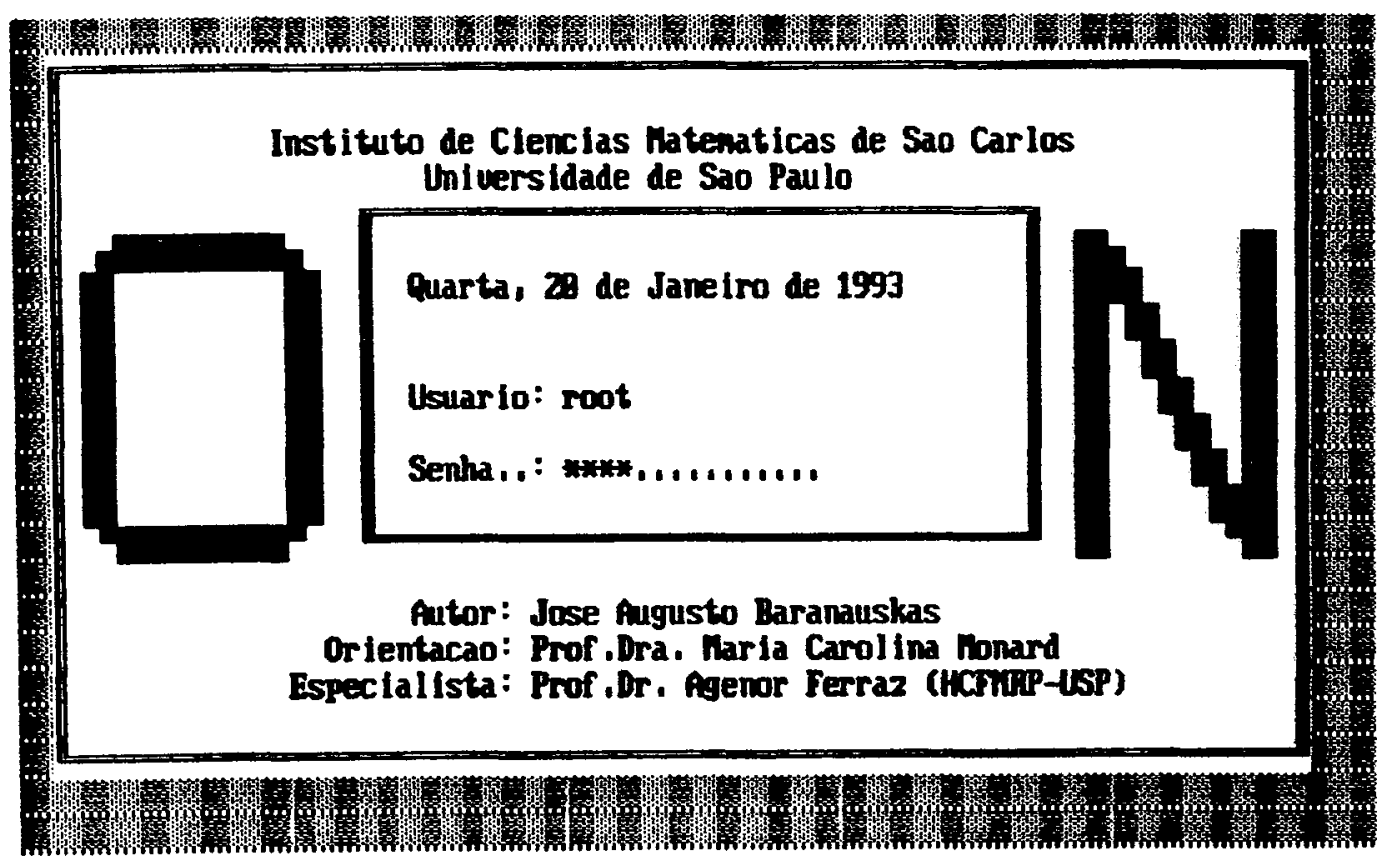

Figura 8.2: Autenticação do Usuário 


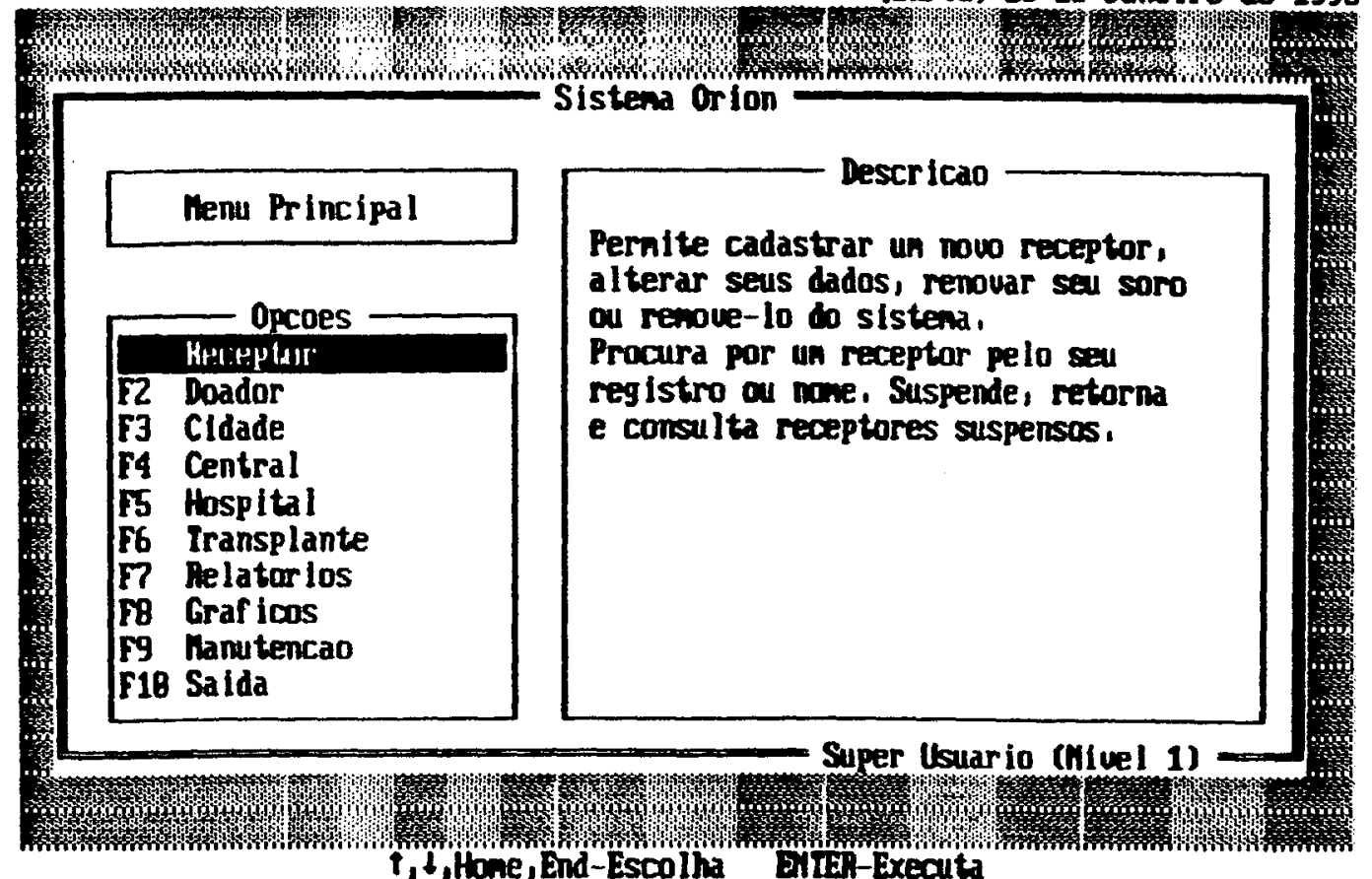

Figura 8.3: Menu Principal

É interessante notar que na moldura inferior à direita é exibido o código do usuário e seu nível de acesso dentro do sistema. ORION permite que seus usuários tenham um dentre três níveis de acesso.

O usuário de nível 1 é o super usuário do sistema, podendo utilizar qualquer uma das suas funções. O usuário, possuindo nível 2, pode executar as mesmas funções que o super usuário, exceto cadastrar novos usuários no sistema ou alterar os parâmetros de seleção de receptores. Já o usuário de nível 3 pode apenas realizar consultas às bases de dados.

\subsubsection{Menus Disponíveis}

Utilizando-se as setas que movimentam o cursor ou as teclas de função, é possível selecionar os sub-menus indicados em Opcoes do menu principal. A cada opção existente em Opcoes, é associada uma Descricao de forma a melhor esclarecer ao usuário do. que pode ser efetuado. A seguir são mostrados alguns desses submenus. 


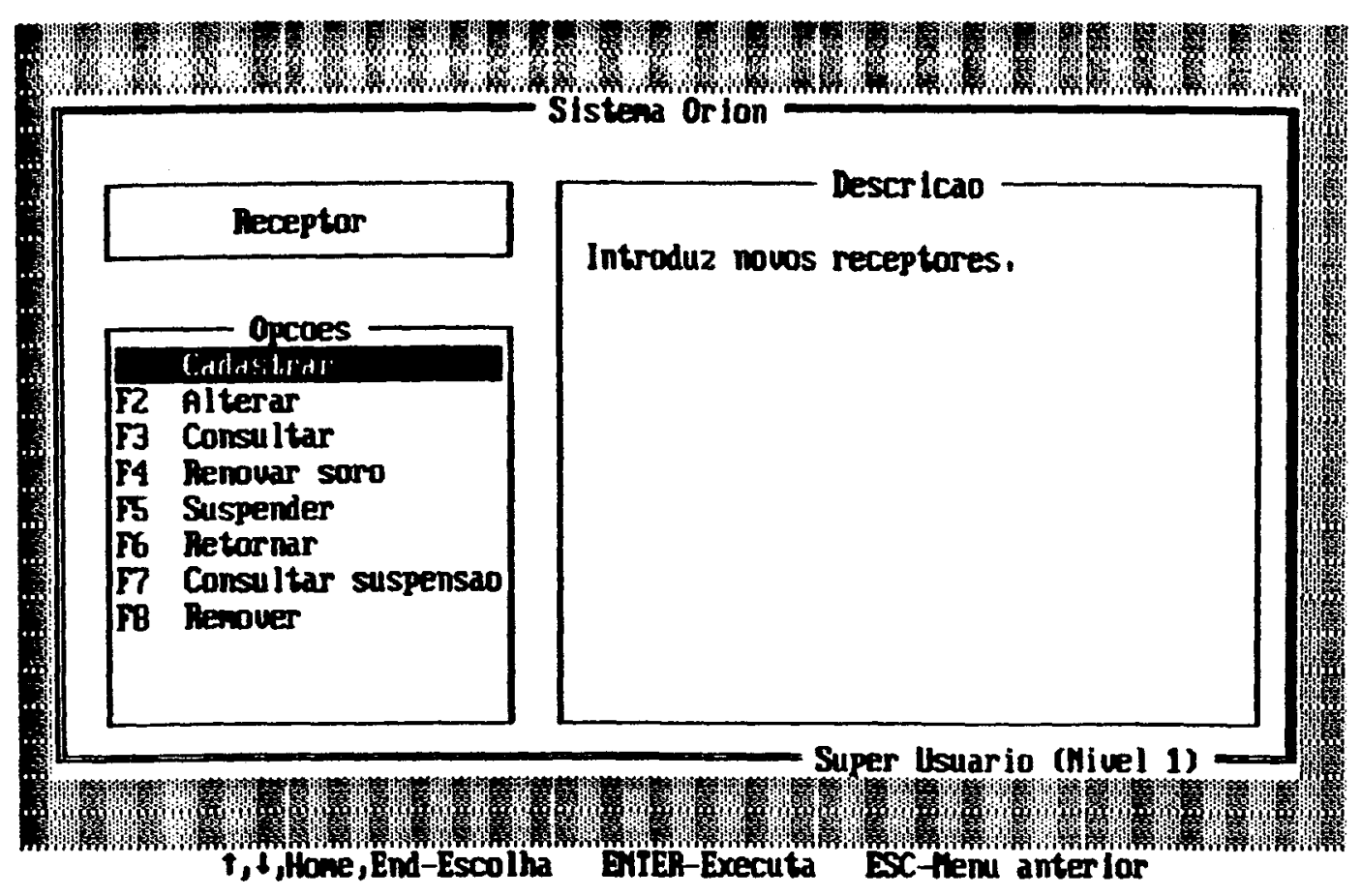

Figura 8.4: Menu Receptor

\section{Receptor}

Quando o usuário seleciona a opção Receptor no menu principal, surge a tela mostrada na Figura 8.4. Para cadastrar um receptor, basta pressionar ENTER ou F1. Com isso, aparece a tela da Figura 8.5.

Uma vez introduzidas as informaçôes sobre o receptor, são efetuadas verificações quanto à consistência desses dados. Caso haja qualquer problema, é mostrada uma mensagem explicativa na última linha da tela. Por exemplo, caso a informação "Sexo" fique em branco e a tecla PgDn seja pressionada, indicando final de entrada de dados (o mesmo acontece se a tecla ENTER for pressionada várias vezes até a última informação da tela), aparecerá a mensagem SEXO: M-MASCULINO F-FEMINIro. Com isso, $O R I O N$ indica ao usuário que as opcões permitidas para "Sexo" são ' $M$ ' ou ' $F$ '. A mesma situação ocorreria caso fosse digitada qualquer outra letra além de ' $M$ ' ou ' $F$ ', como mostra a Figura 8.6.

Somente quando todas as informações introduzidas forem validadas é que o sistema permitirá que elas sejam gravadas na base de dados - Figura 8.7, página 80 . Entretanto, no caso especial de receptores, após a validação das informações pode aparecer uma janela de aviso. Essa janela aparece apenas quando os dados introduzidos indicarem que aquele receptor não está apto a receber um transplante, de acordo com os parâmetros de seleção fixados - Figura 8.8, página 80. 
Sistena orion

| Cadastrar | Receptor

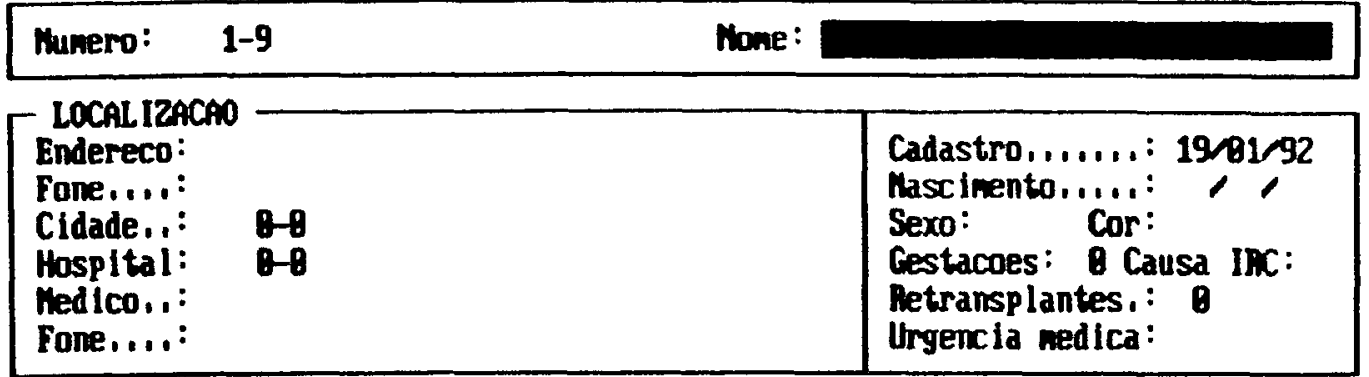

$\left[\begin{array}{llll}\text { ABO } \\ \text { Grupo ABO: }\end{array}\right.$

\begin{tabular}{|c|c|c|}
\hline$A: \begin{array}{l}(B, B) \\
B(B, B)\end{array}$ & $B: \begin{array}{l}\theta \\
\theta \\
\theta(B, B)\end{array}$ & DS: $\begin{array}{l}\theta(B, B) \\
B(B, B)\end{array}$ \\
\hline
\end{tabular}

PRA
PRA:
Ma ior PRA:

Figura 8.5: Cadastro de Receptor não Preenchido

Sistena Orion

| Cadastrar | Receptor

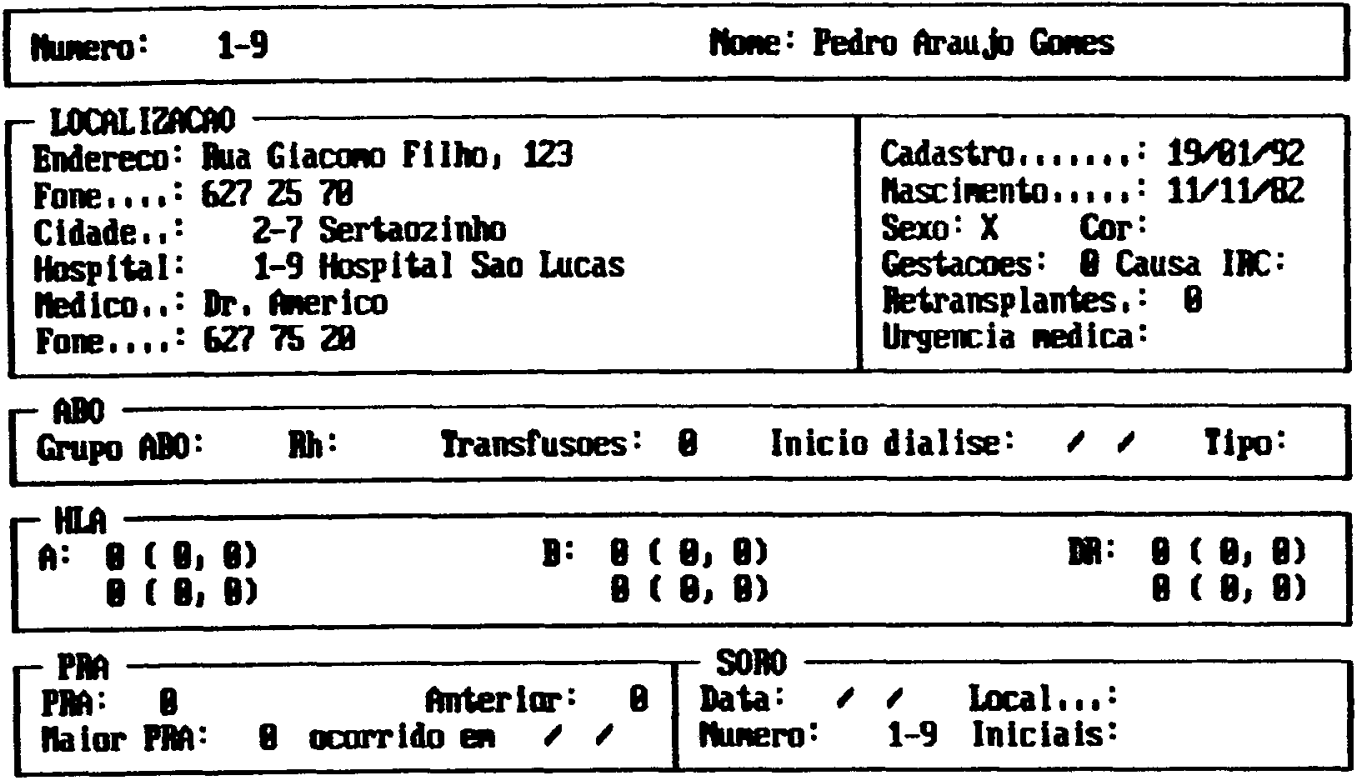

SEXo: n-mascallino E-FEIIMIno

Figura 8.6: Mensagem de Erro Exibida Quando o Sexo é Diferente de ' $M$ ' ou ' $F$ ' 


Munero: 1-9 Mone: Pedro Araujo Cones

\begin{tabular}{|c|c|}
\hline $\begin{array}{l}\text { Endereco: Rua Glacomo Filho, } 123 \\
\text { Fone....: } 6272578 \\
\text { Cldade.: } 2-7 \text { Sertaozinho } \\
\text { Hospital: } 1-9 \text { Hospital Sao Lucas } \\
\text { Hedico..: Dr. Americo } \\
\text { Fone...: } 6277528\end{array}$ & 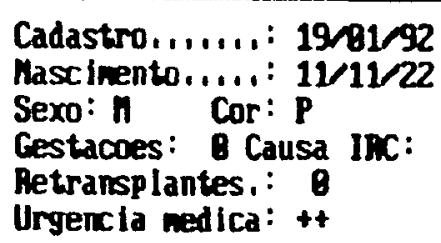 \\
\hline
\end{tabular}

Grupo ABO: Rh: + Iransfusoes: 1 Inicio dialise: , , Tipo:

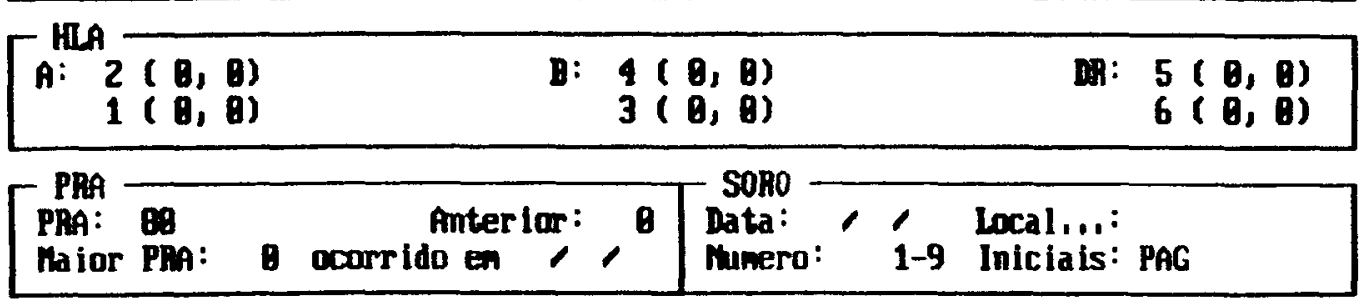

Conf Irma I S-Sin M-Hao A-Altera

Figura 8.7: Cadastro de um Receptor

Sistena Orion

| Cadistrar | Peceptor

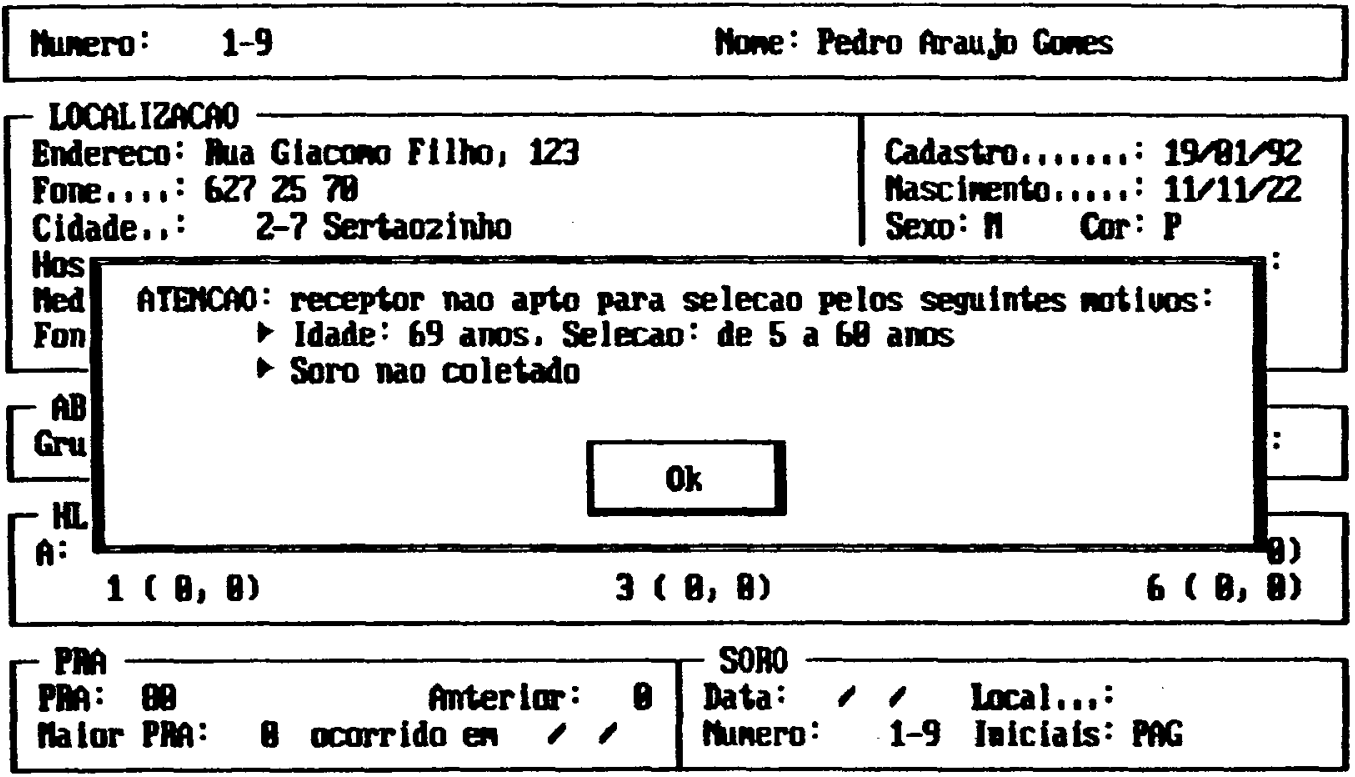

Figura 8.8: Janela de Aviso 
As telas de alteração, consulta e remoção são similares à tela de cadastro. $\mathrm{Na}$ tela de consulta, os dados dos receptores podem ser consultados de duas formas. Uma forma consiste em fornecer o número do receptor. Caso o receptor esteja cadastrado, suas informaçôes são exibidas. A partir desse instante, é possível movimentar-se para o receptor anterior ou posterior àquele solicitado.

Outra forma de consulta consiste em fornecer o nome, ou apenas parte dele. São exibidos, assim, todos o receptores que possuem aquele nome. Por exemplo, se desejar-se saber quais os receptores que possuem nome 'Marcos', seriam mostrados os receptores com nomes 'Marcos José da Silva', 'José Marcos da Silva', 'José da Silva Marcos' e todos aqueles que possuíssem 'Marcos' como parte de seu nome. Este tipo de consulta encontra-se também disponível para 'Cidade','Hospital' e 'Central'.

Como foi citado no Capítulo 4, ocasionalmente um receptor pode ser suspenso do processo de alocação. Para suspender um receptor basta selecionar a opção Suspender na tela mostrada na Figura 8.4, página 78. Com isso, aparece a tela como indica a Figura 8.9.

Para consultar as suspensões de um receptor, basta selecionar a opção Consultar suspensao e a tela correspondente à Figura 8.10 é exibida. Nessa tela, são mostradas todas as suspensões que um receptor já teve, com a indicação da data da suspensão, motivo e data de retorno da suspensão aplicada. Caso o receptor ainda esteja suspenso, uma mensagem indica esse fato.

Doador

Estando na tela indicada pela Figura 8.3, página 77 e pressionando-se F2, obtemse o menu Doador. Nesse menu, é possivel Cadastrar, Alterar, Consultar ou Remover um doador do sistema. Se, nessa última tela for pressionado F1, surge a tela de cadastro de doadores no sistema - Figura 8.11, página 83.

\section{Hospital}

Com a seleção da opção Hospital no menu principal, a tela mostrada na Figura 8.12, página 83, é apresentada. Percebe-se que ela possui funçôes similares àquelas do menu Receptor.

Selecionando-se a opção Alterar é requisitado o número do hospital e, caso ele já esteja cadastrado, é fornecida a tela conforme mostra Figura 8.13, página 84. 


Munero: 1-9 Mome: Pedro Araujo Cones

SUSPEISAO

Data: 1B/B1/93 hot1va: Exane sangue

Conf Irma suspensao I S-SIn M-Mao A-Altera

Figura 8.9: Suspensão de Receptor

Sistema Orion | Consultar Suspensao | Beceptar

Munero: 1-9 Mone: Pedro Arraubo Cones

\begin{tabular}{|c|c|c|}
\hline Data & Motivo & Detorno \\
\hline $18 / 81 / 93$ & Bxare sangue & SUSPBSD \\
\hline $\begin{array}{l}80 / 82 / 92 \\
22 / 94 / 92 \\
15 / 87 / 92\end{array}$ & $\begin{array}{l}\text { Exares sangue } \\
\text { Bxare HIU } \\
\text { Exare sangue }\end{array}$ & $\begin{array}{l}18 / 93 / 92 \\
15 / 6 / 92 \\
28 / 87 / 92\end{array}$ \\
\hline
\end{tabular}

Pressione qualquer tecla para continuar ...

Figura 8.10: Consulta d̀s Suspensões de um Receptor 
Munero: 3-5

Idade, : $35 \quad$ Sexo: F Cor: A Causa morte: A1

Cidade: 4-3 Sao Carlos

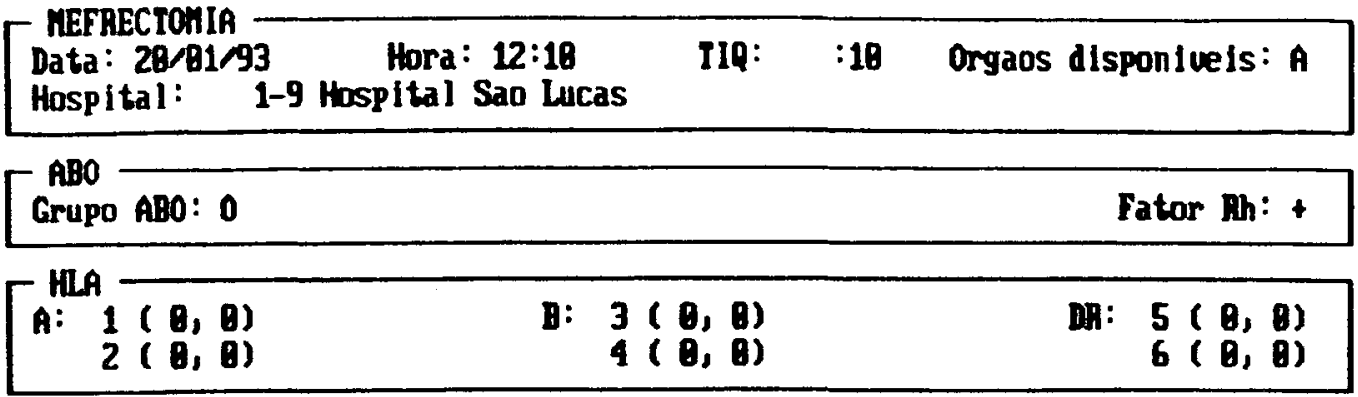

Conf Irma ? S-Sin M-Hao A-Altera

Figura 8.11: Cadastro de Doador

Quarta, 28 de Janeiro de 1993

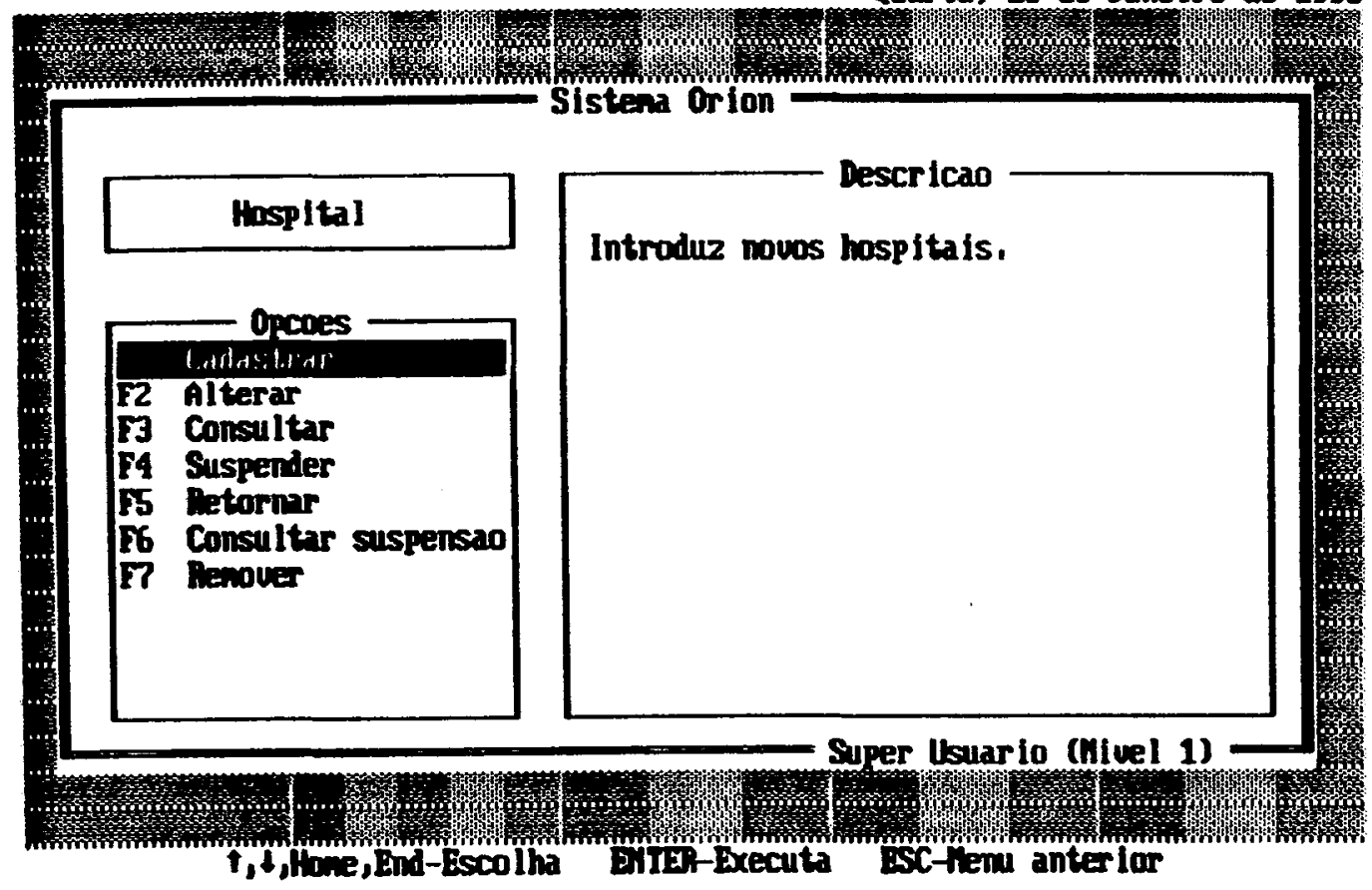

Figura 8.12: Menu Hospital 
Munero: 1-9 Razao social: Hospltal Sao Irancisco

Cidade.,: 1-9 Ribeirao Preto

Endereco: Mua Bernardinho de Canpos, 123

Telef one: $633-3333$

Contato.: Srta, Amella

Itpo..... I

Central,: 1-9 SPIT

Conf Irma ? S-Sin M-Hao A-Altera

Figura 8.13: Alteração de Hospital

\section{Cidade e Central}

As opções Cidade e Central do menu principal possuem telas similares, tendo o número e o nome das cidades e centrais hospitalares. Como já descrito anteriormente, uma central engloba vários hospitais e cada hospital pertence a uma única central.

\section{Transplante}

Utilizando-se a opção Transplante do menu principal indicado pela Figura 8.3, página 77, é possível alterar os parâmetros de seleção de receptores - Figura 8.14. Nessa tela pode-se alterar o intervalo de idade dos receptores que podem recebem um transplante, o número máximo de doadores que devem ser selecionados para o exame de Cross-Match, etc.

Outra opção do menu Transplante permite que a seleção de receptores - com base nos parâmetros fixados na tela indicada pela Figura 8.14 - seja efetuada. Isso pode ser visto na Figura 8.15. Com a seleção, o pré-processador é ativado criando as asserções no formato entendido pelo Sistema Baseado em Conhecimento. 


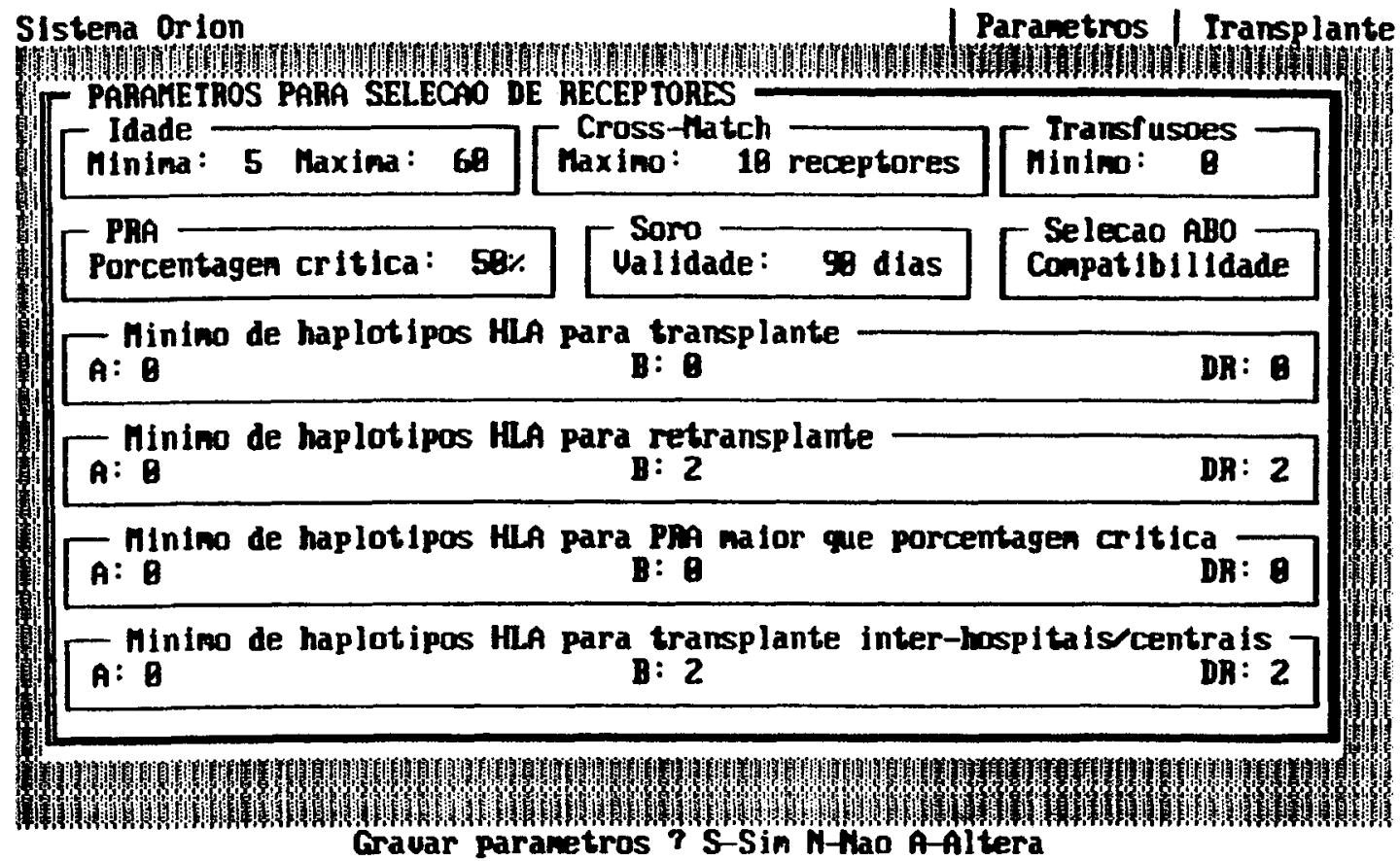

Figura 8.14: Alteração de Parâmetros

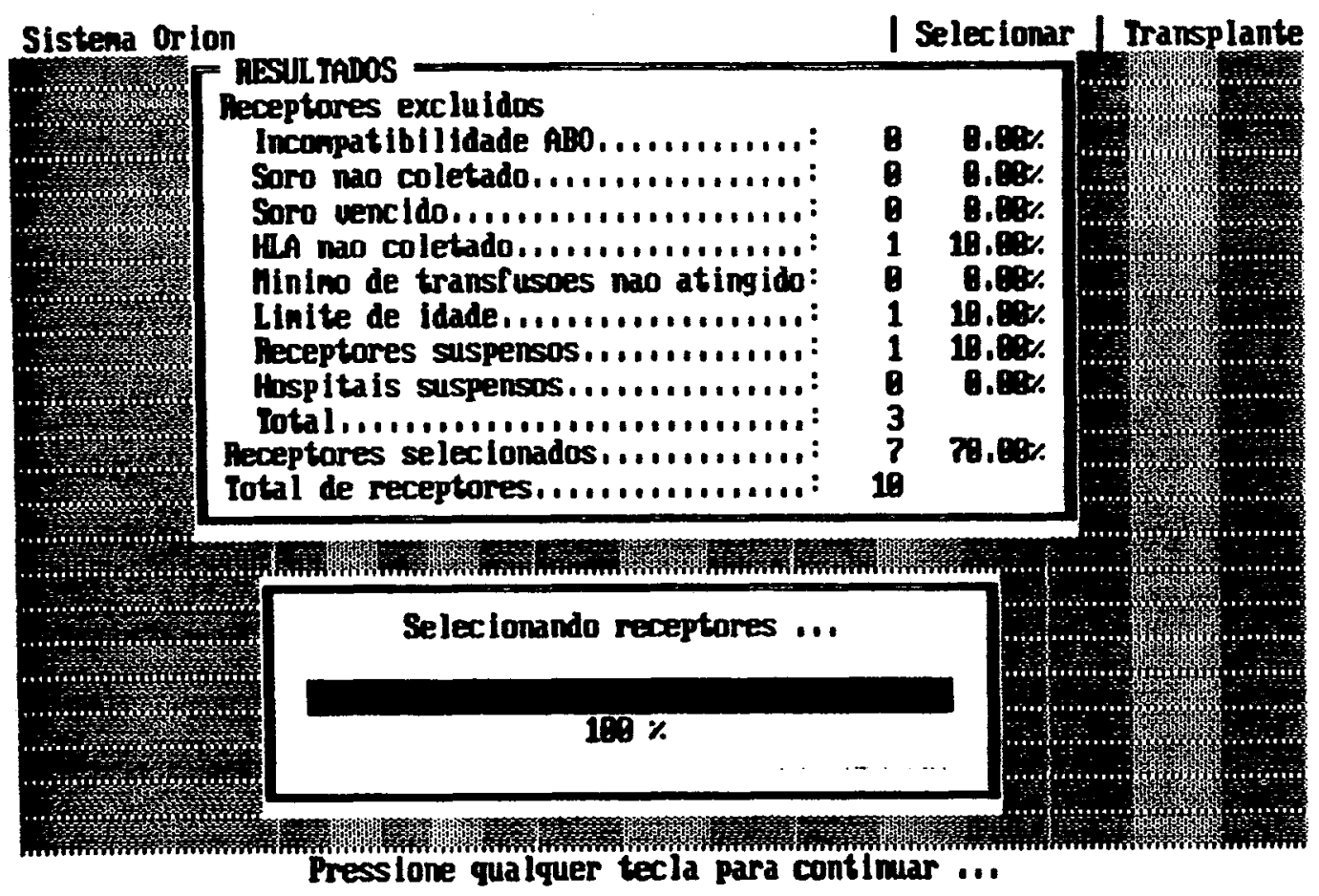

Figura 8.15: Seleção de Receptores 


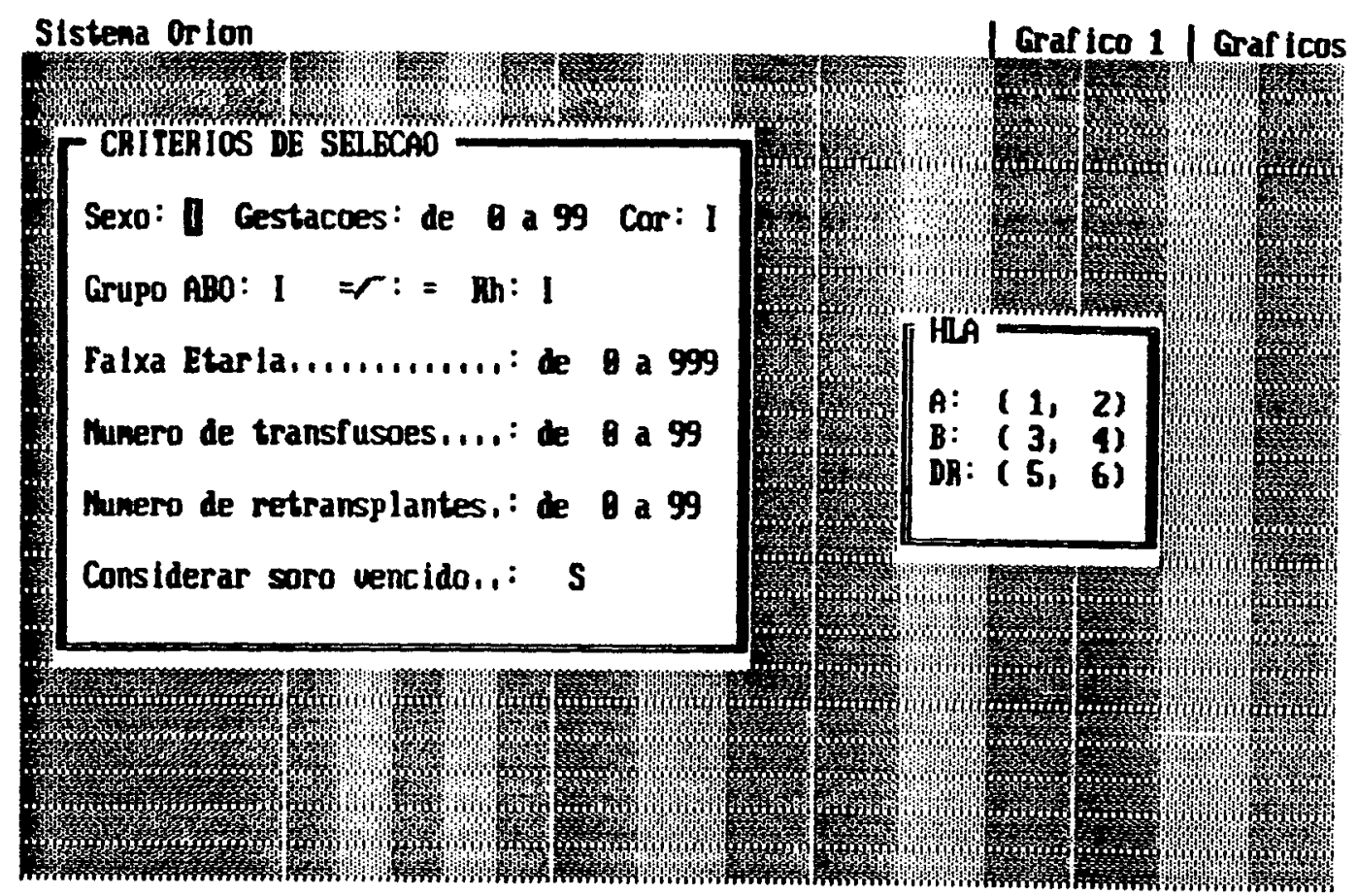

Figura 8.16: Opções para Seleção de Receptores na Construção de Gráfico

\section{Graficos}

$\mathcal{O R I O N}$ tem capacidade de construir alguns tipos de gráficos considerados relevantes pelos especialistas médicos. Esses gráficos foram desenvolvidos com o intuito de permitir uma melhor compreensão das informações [Leone 92].

- Grafico G1

Esse, como os outros gráficos, pode ser construido pela seleção de receptores de determinado sexo, cor, grupo $A B O$, fator $\mathrm{Rh}$, faixa etária, faixa de número de transfusōes, retransplantes e aqueles com soro vencido, como indica a Figura 8.16. Os demais gráficos possuem telas similares a essa última.

Uma vez escolhidos esses critérios para a elaboração, é construído o gráfico mostrado na Figura 8.17. Nele são exibidas as porcentagens de loci HLA dos receptores que são iguais a de um determinado doador. Os números entre parênteses indicam a freqüência absoluta de receptores.

- Grafico G2

No gráfico indicado pela Figura 8.18 são mostrados a porcentagem e o número de receptores que encontram-se em até 10 intervalos pré-definidos, ou definidos pelo usuário, de porcentagem de $P R A$. 


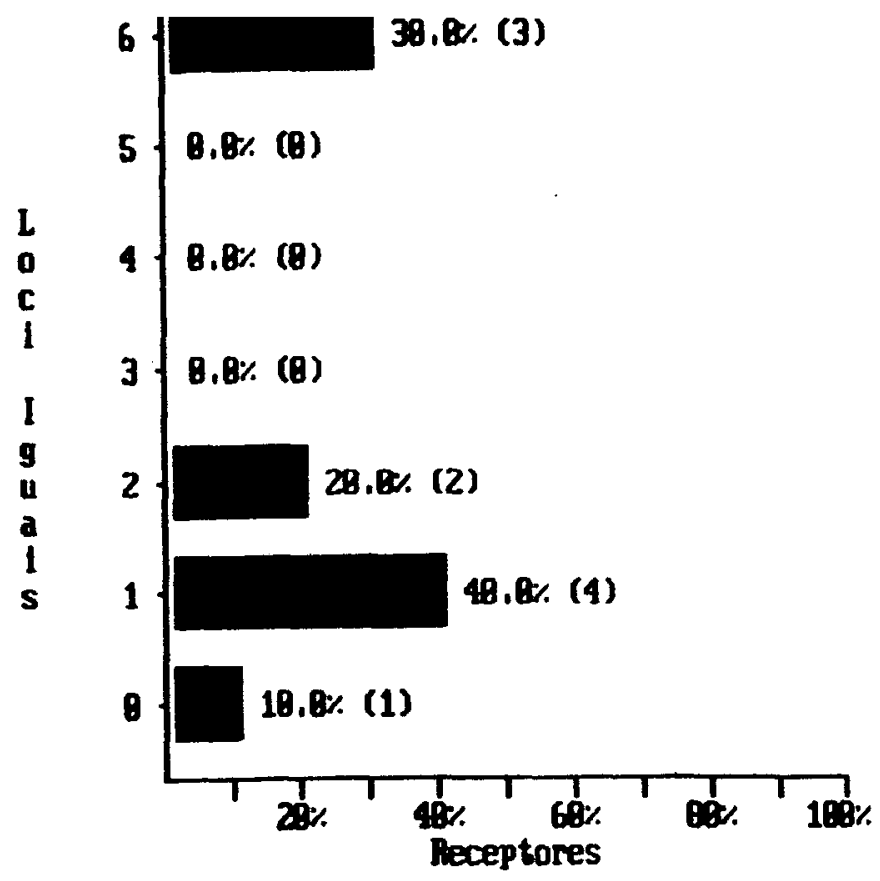

Igua ldades

ILA-A.: 13

HIA-B,: 6

MLAR: ?

Figura 8.17: Gráfico de Distribuição de HLA de um Doador Comparado com o HLA da População de Receptores

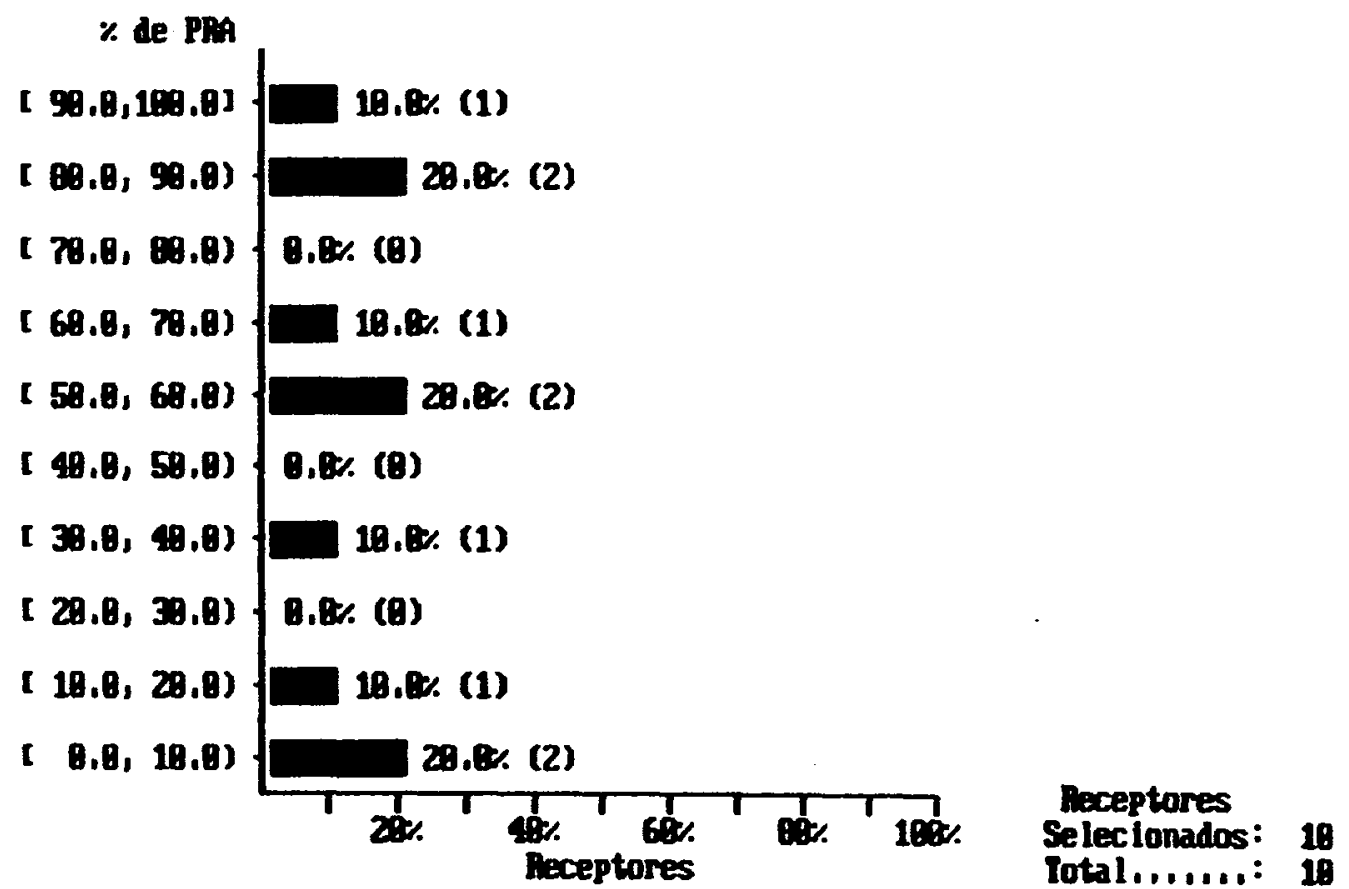

Figura 8.18: Gráfico de Distribuição da Porcentagem de PRA na População de Receptores 


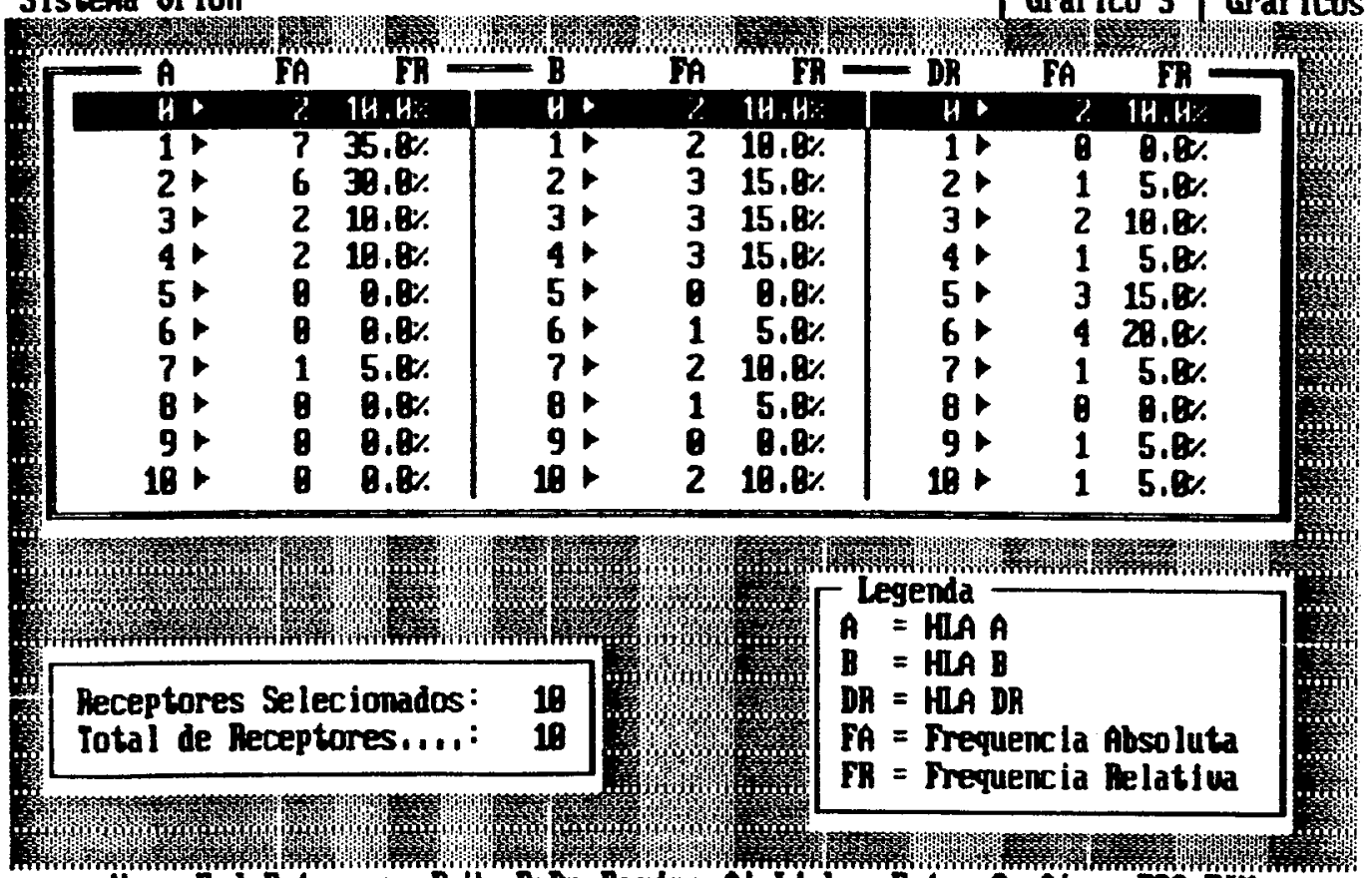

Hone,End-Extrenos Pylp,PgDn-Pag ina th-Linha Enter-Graf ico ESC-FIn

Figura 8.19: Freqüência dos loci HLA na População de Receptores
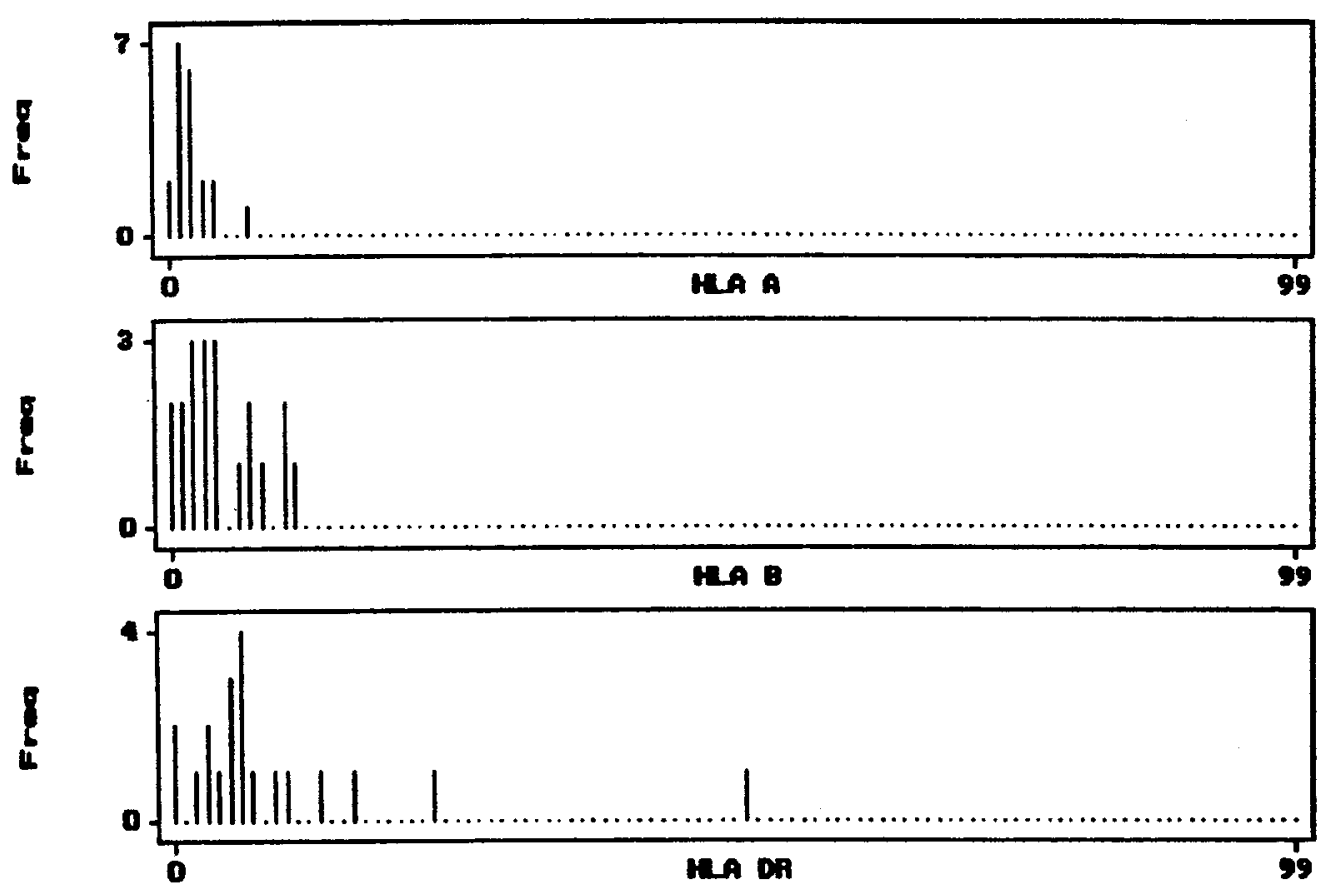

Figura 8.20: Gráfico de Freqüência dos loci HLA na População de Receptores (Sem Conectar as Linhas) 

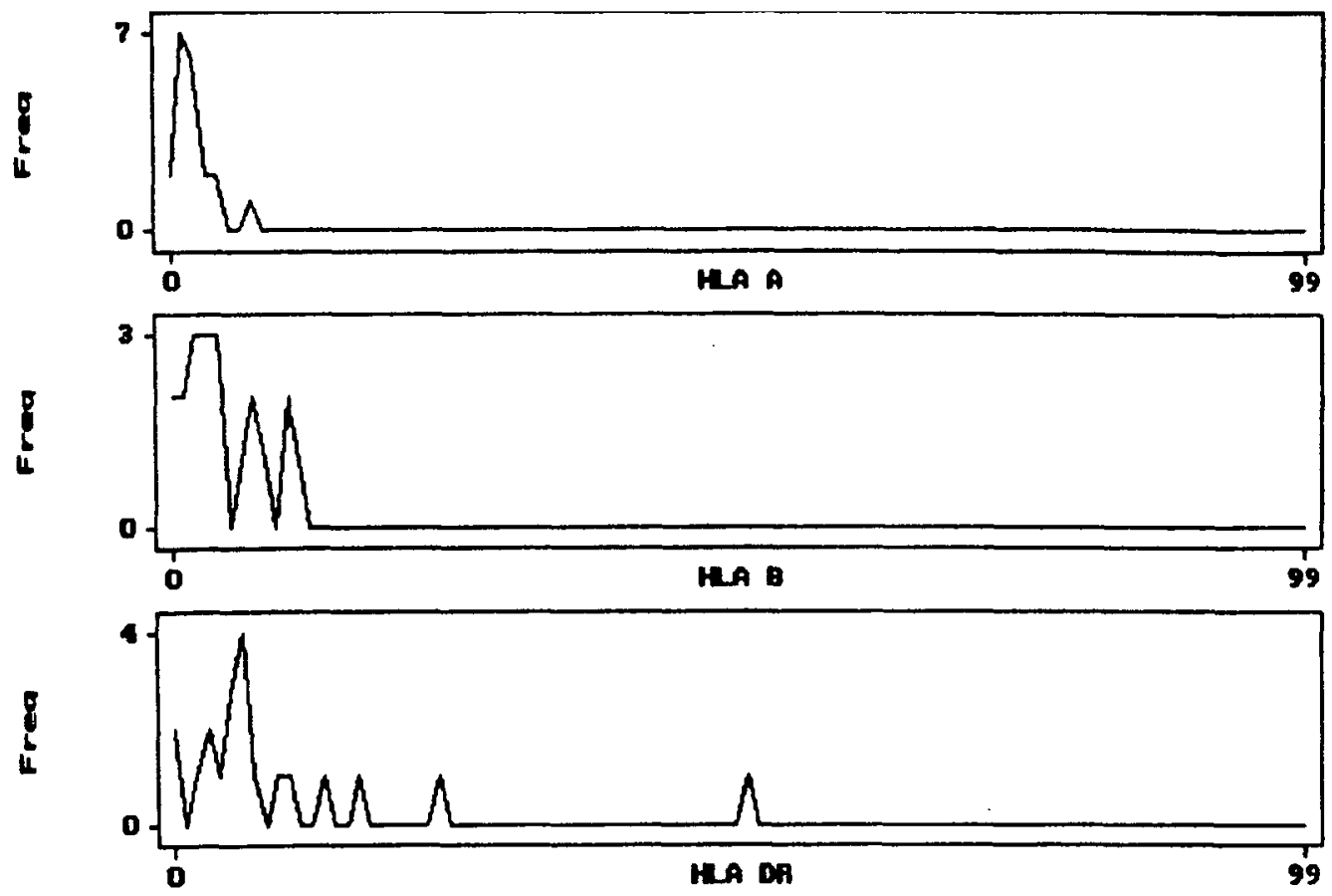

Figura 8.21: Gráfico de Freqüência dos loci HLA na População de Receptores (Linhas Conectadas)

- Grafico G3

Antes de ser mostrado esse gráfico, é exibida uma tela contendo informações numéricas, como mostra a Figura 8.19. Após isso, a tela da Figura 8.20 mostra o gráfico de freqüência dos loci HLA-A, HLA-B e HLA-DR na população de receptores. Esse gráfico também pode ser construído conectando-se os pontos, como mostra a Figura 8.21.

\section{Manutencao}

Nesse menu é possível alterar alguns parâmetros de operação do sistema, por exemplo, o uso ou não de aviso sonoro em condições de erro, redirecionamento da impressão para um arquivo, etc.

Também é possivel realizar a reorganização de arquivos. Isso é devido ao fato que, quando se remove algum registro de uma base de dados, ele é removido apenas logicamente. Com a reorganização, esses registros são removidos fisicamente.

Por último, essa opção permite que novos usuários de $O R I O \mathcal{N}$ sejam cadastrados, alterados, consultados ou removidos. Como já descrito, cada usuário possui 
Codigo: root

Ussar lo: Super Usuario

Nivel de autorlzacao:1

\begin{tabular}{|c|c|c|c|c|c|c|c|c|}
\hline Data & Hora & CID & HOS & SHos Cit & В.CP SRCP & DDR & IPL & $\mathrm{ACC}$ \\
\hline $\begin{array}{l}12 / 12 \times 92 \\
14 / 12 \times 92 \\
15 / 12 \times 92 \\
15 / 12 \times 92 \\
18 / 12 / 92 \\
23 / 12 \times 92 \\
23 / 12 / 92 \\
27 / 12 \times 92 \\
82 / 81 / 93 \\
12 / 81 / 93\end{array}$ & $\begin{array}{l}89: 14: 89 \\
89: 16: 54 \\
89: 19: 59 \\
29: 49: 35 \\
23: 87: 33 \\
66: 36: 83 \\
67: 12: 39 \\
18: 39: 19 \\
22: 11: 28 \\
17: 17: 36\end{array}$ & $\begin{array}{l}\bar{z} \\
- \\
- \\
- \\
\bar{z} \\
\overline{-} \\
-\end{array}$ & $\begin{array}{l}= \\
- \\
- \\
= \\
- \\
-\end{array}$ & 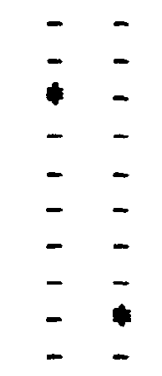 & $\begin{array}{l}- \\
- \\
- \\
- \\
- \\
- \\
- \\
-\end{array}$ & $\begin{array}{l}- \\
\bar{y} \\
- \\
\bar{z} \\
\overline{-} \\
\overline{-} \\
-\end{array}$ & $\begin{array}{l}\overline{-} \\
\bar{z} \\
\bar{z} \\
\bar{z} \\
\bar{z} \\
\bar{z}\end{array}$ & $\begin{array}{l}- \\
\bar{y} \\
- \\
- \\
- \\
- \\
-\end{array}$ \\
\hline
\end{tabular}

CID $=$ Cidade hOS=Hospital SHOS=Suspensao-hospital CrT=Central $\mathrm{MCP}=$ heceptar $S R C P=S u s p e n s a 0-$ Receptor $D D R=D o a d o r \quad I P L=$ Iransplante $A C C=$ fcesso *hodif icacoes

PgUp-Amterior PgDn-Posterior End-Fin

Figura 8.22: Consulta aos Acessos de um Usurio no Sistema

um código, uma senha e um nível de segurança para utilizar $\mathcal{O R I O N}$. Na tela de consulta - Figura 8.22 - são também mostradas as últimas utilizações que cada usuário efetuou, juntamente com as bases de dados modificadas em cada ocasião.

\subsection{O SBC de $\mathcal{O} \mathcal{I O N}$}

Quando é efetuada uma seleção - Figura 8.15, página 85 - o usuário é arguído se deseja ativar o Sistema Baseado em Conhecimento para continuar o processo de alocação de rins.

Ao ser ativado, o SBC mostra a tela indicada na Figura 8.23. Após pressionar-se uma tecla, é mostrado o menu da Figura 8.24

É possivel notar que a interface utilizada é bem mais simples do que aquela do SBD. O motivo desse fato é explicado na Seção 9.3, página 101. 


\author{
Orion \\ Un Sistema Baseado en Conkecirento \\ para fuxilliar mo Processo \\ de Alocacao de Rins
}

\begin{abstract}
Putor: Jose Augusto Baranauskas
Oriemtadora: Profa, Dra, Marla Carolina Monard

Especialista: Prof, Dr, Agenar Ferraz (HCFMRP-LSP)

ICTSC - USP - San Carlos

Iecle TESC para sair ou outra tecla para continuar
\end{abstract}

Figura 8.23: Tela de Apresentação

Sistena Orion

Quarta, 20 de Janeiro de 1993

Opcoes disponlueis:

1. Inf ornacoes gera is

2. Alterar os fatores utillzados no processo de alocacao

3. Alterar os fatores utillizadus no desenpate

4. At luar processo de alocacao

5. Pontuacao ins receptores selecionados

6. Bxplicar cono o sistena chegou a una solucan

7. Relatar io sobre o processo de alocacao

8. Salda

axt

Figura 8.24: Menu Principal 


\subsubsection{Menus Disponiveis}

A seleção de opções no Menu Principal é efetuada pressionando-se qualquer um dos números indicados à esquerda de cada opção e em seguida a tecla ENTER. As seçóes seguintes mostram alguns exemplos de cada um deles.

\section{Informacoes gerais}

De forma a facilitar o usuário, nesse menu são fornecidas informações referentes às opções existentes no sistema. Também são explicadas quais as ações que o usuário pode tomar quando o sistema requisita alguma informação.

Alterar os fatores utilizados no processo de alocacao

Nessa opção, o usuário pode "ligar" ou "desligar" alguns fatores para testar hipóteses. Ao ativar essa opção, o sistema mostra os fatores ativos naquele momento, conforme pode ser observado na Figura 8.25. Caso seja digitado ENTER, $\mathcal{O R I O N}$ mostra todos os fatores disponíveis - Figura 8.26.

Para alterar algum fator, basta escrever seu nome, pressionar ENTER e indicar se ele deve ou não ser considerado no processo de alocação. Isso pode ser visto na Figura 8.27, página 94. Ao final, basta que o usuário digite pare para que os novos fatores ativos sejam armazenados permanentente.

Alterar os fatores utilizados no desempate

Essa opção possui interface similiar à opção Alterar os fatores utilizados no processo de alocacao. Ela é utilizada para definir quais fatores devem ser considerados no desempate de dois ou mais receptores com a mesma pontuação.

Ativar processo de alocacao

Ao ativar o processo de seleção de receptores, o sistema exibe a tela mostrada na Figura 8.28, página 94 .

Durante a execução, podem ser necessárias informações adicionais ao SBC. Nesse caso ele as requisita ao usuário - Figura 8.29, página 95. Nesse instante, o 
Opcoes disponivels:

1. Inf armacoes gerais

2. Alterar os fatores utllizados no processo de alocacao

3. Alterar os fatores utllizados no desenpate

4. Atluar processo de alocacao

5. Pontuacao dos receptores selecionados

6. Explicar cono o sistena chegou a una solucao

7. Relator io sobre o processo de a locacao

8. Salda

*** 2

Fatores atualnente considerados no processo de selecao:

(prinario): abo rh hla splits

(secundario): transfusao retransplante painel gestacao

(terciario): dialise urgencia nedica tenpode_cadastro

Fator:

***

Figura 8.25: Verificando os Fatores Utilizados na Alocação de Rins.

Sistena Orion

Cuarta, 28 de Janeiro de 1993

*** 2

Fatores atualmente considerados no processo de selecao:

(prinario): abo rh hla splits

(secundario): transfusao retransplante painel gestacao

(terciario): dialise urgenciamedica tenpo-de cadastro

Fator:

iator

Respostas validas (digite 'pare' para parar):

(prinarlo): abo rh hla spilts

(secundario): transfusao retransplante painel gestacao distancia

(terciario): dialise urgenclanedica ldade tenpo de_cadastro

Fatares atualnente considerados no processo de selecao:

(prinario): abo rh hla splits

(secundario): transfusao retransplante painel gestacao

(terciario): diallse urgencla_nedica tempo_de_cadastro

Fatar:

***

Figura 8.26: Verificando todos os Fatores Disponiveis. 
Fator:

**x

Respostas validas (digite 'pare' para parar):

(prinario): abo rh hla splits

(secundario): transfusao retransplante painel gestacao distancia

(terciario): dialise urgencianedica idade tenpo_de cadastro

Fatores atualnente considerados no processo de selecao:

(prinario): abo rh hla splits

(secundar10): transfusao retransplante palnel gestacao

(terciario): dialise urgencia_nedica tempo_de_cadastro

Fator:

*** distancia

Considerar fator 'distancla' no processo de selecao ? (s on $n$ )

** 5

Fator:

** pare

Figura 8.27: Alterando os Fatores Utilizados na Alocação de Rins.

Sistema orion

Quarta, 29 de Janeiro de 1993

Selecao efetuada en $28 / 1 / 93$

Munero de receptares: 17

- Beceptar en aval lacao AUIBPA CAIXIA RIBEImo

\begin{tabular}{|c|c|c|}
\hline $\begin{array}{ll}\text { Fatares Prinarios } \\
\text { - Grupo ABO } & 1 \\
\text { - Fator Bh } & 8 \\
\text { - HA } & 8 \\
\text { - Splits HLA } & 0\end{array}$ & $\begin{array}{l}\text { Patares Secundarios } \\
\text { - Transfusao } 2 \\
\text { - Retransp lante } \\
\text { - Palnel } \\
\text { - Gestacao } \\
\text { - Distancia }\end{array}$ & $\begin{array}{l}\text { Fatares Terclarios } \\
\text { - Tenpo de Dialise } \\
\text { - Urgencia Medica } \\
\text { - Idade } \\
\text { - Tenpo de Cadastro }\end{array}$ \\
\hline
\end{tabular}

Figura 8.28: Selecionando Receptores. 
Selecao ef etuada en $28<1<93$

hunero de receptares: 17

Quanto tenpo (en horas) resta para que o transplante possa ser ef etuado ?

***

Figura 8.29: Pergunta feita ao Usuário.

usuário pode questionar por que o sistema está fazendo uma pergunta, conforme Figura 8.30. Caso o usuário queira mais informações, ele novamente requisita uma explicação ao sistema - Figura 8.31.

Ao término do processo de alocação, são mostrados os receptores conforme descrito na opção seguinte.

Pontuacao dos receptores selecionados

Após efetuado o processo de seleção, o usuário pode visualizar a pontuação referente a todos os receptores, Figura 8.32, página 97, os receptores selecionados para Cross-Match, Figura 8.33, página 97, e os receptores desempatados, Figura 8.34, página 98.

Explicar como o sistema chegou a uma solucao

Após realizado o processo de seleção, o sistema tem a capacidade de explicar como chegou a uma solução - como mostra a Figura 8.35, página 98. 
Selecao ef etuada en $28<1<93$

hurero de receptores: 17

Quanto tempo (en horas) resta para que o transplante possa ser ef etuado? * 25

Dual o tenpo (en huras) de percurso entre Sertaozinho e Ribeirao Preto? ** par-que

SE

- tenpo restante para a realizacao do transplante $e^{2} 25$ horas $E$ $E^{\prime}$ possivel deterninar o tenpo de percurso

emtre Sertacointo e Ribelrao Preto E

o tempo de viagen e' menor que 25 horas

Bitho

E' possivel loconover-se de Sertaozinho para Ribeirao Preto

en tempo para realizar o transplante

Qual o tenpo (en huras) de peraurso entre Sertazinho e Ribeira Preto?

**

Figura 8.30: Usuário Questiona “por que” o Sistema Necessita uma Informação.

Sistena orion

Quarta, 28 de Janeiro de 1993

en tenpo para realizar o transplante

Qual o tenpo (en horas) de percurso entre Sertaozinho e Ribeira Preto? ** por-que

Foi prouado que:

o fator secumdario 'distancia' esta' habilitado

Qual o tenpo (en haras) de percurso entre Sertaozinho e Ribeira Preto?

** Par-que

STP

- fatar secundario 'distancla' esta' habilitado E

E' possivel locomover-se de Sertaozinho para Ribeirao Preto

en tenpo para reallzar o transplante Bimo

fALBB CARCIA BIBEIMO (3-5) ten condicoes de chegar ate

Sertacoinho para realizar o transplante

Qual o tenpo (en huras) de peraurso entre Sertarzinho e Bibeira Preto? a*

Figura 8.31: Usuário Questiona novamente “por que” o Sistema Necessita uma Informação. 


\begin{tabular}{|c|c|c|}
\hline 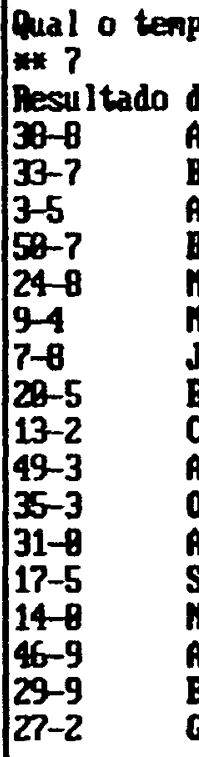 & 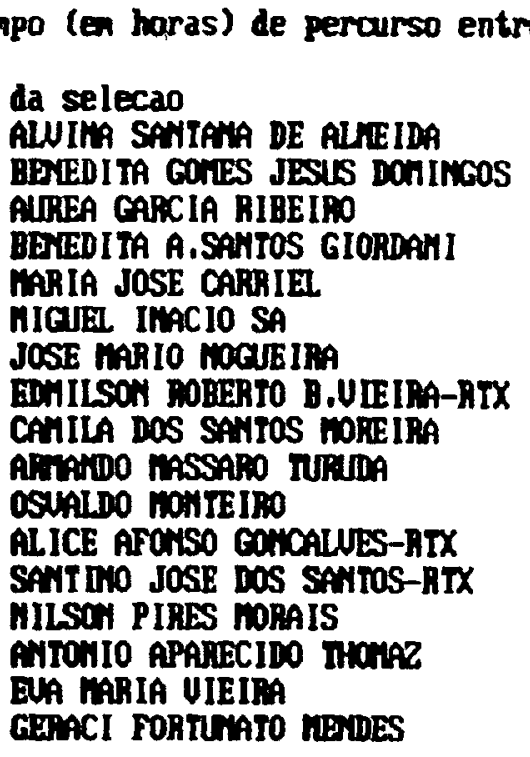 & $\begin{array}{l}11.5 \\
11.5 \\
11.8 \\
9.8 \\
8.5 \\
8.8 \\
7.8 \\
7.8 \\
7.8 \\
6.5 \\
6.5 \\
6.5 \\
6.5 \\
6.5 \\
6.8 \\
5.5 \\
5.5\end{array}$ \\
\hline
\end{tabular}

Pressione qualquer tecla para continuar...

Figura 8.32: Pontuação dos Receptores.

Sistema Orion Quarta, 20 de Janeiro de 1993

\begin{tabular}{|c|c|c|}
\hline $\begin{array}{l}46-9 \\
29-9 \\
27-2\end{array}$ & 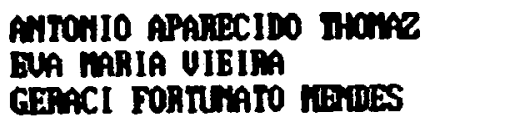 & $\begin{array}{l}6.8 \\
\mathbf{5} .5 \\
\mathbf{5 . 5}\end{array}$ \\
\hline $\begin{array}{l}\text { Paciemtes } \\
30-8 \\
39-7 \\
3-5 \\
50-7 \\
24-8 \\
9-4 \\
7-8 \\
28-5 \\
17-2 \\
49-3 \\
35-3 \\
31-8 \\
17-5 \\
14-8\end{array}$ & 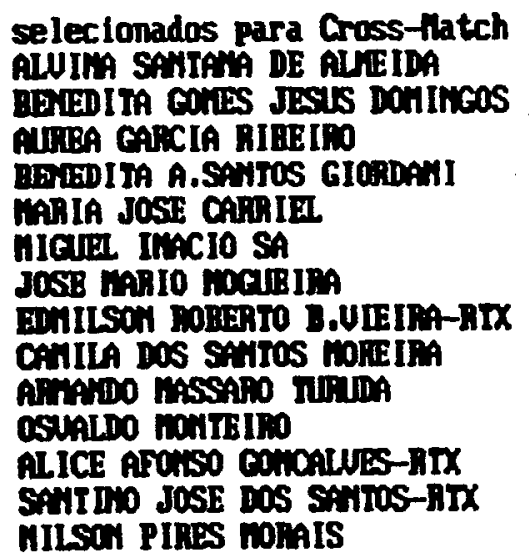 & $\begin{array}{l}11.5 \\
11.5 \\
11.8 \\
9.8 \\
8.5 \\
8.8 \\
7.8 \\
7.8 \\
7.8 \\
6.5 \\
6.5 \\
6.5 \\
6.5 \\
6.5\end{array}$ \\
\hline
\end{tabular}

Presslone qualquer tecla para continuar...

Figura 8.33: Receptores Selecionados par Cross-Match. 


\begin{tabular}{|c|c|}
\hline $\begin{array}{l}31-8 \\
17-5 \\
14-8\end{array}$ & $\begin{array}{l}\text { ALICE AFOUSO COHCALUES-RTX } \\
\text { SPNTIIIO JOSE DOS SPNITS-RTX } \\
\text { MILSOH PIRES MOBAIS }\end{array}$ \\
\hline $\begin{array}{l}\text { Pacientes } \\
33-7 \\
30-8 \\
3-5 \\
58-7 \\
24-8 \\
9-4 \\
13-2 \\
20-5 \\
7-8 \\
14-8 \\
17-5 \\
31-8 \\
35-3 \\
49-3\end{array}$ & 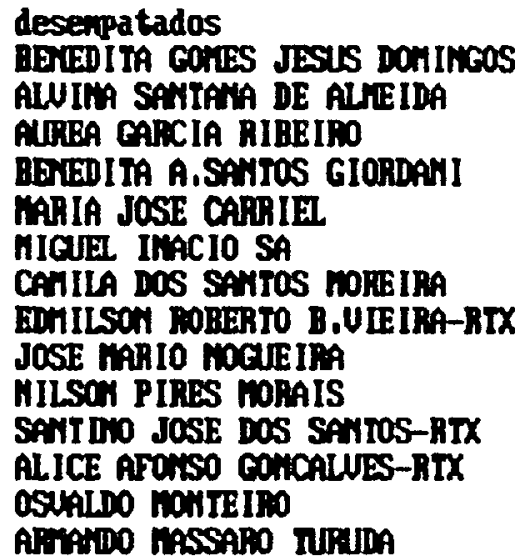 \\
\hline
\end{tabular}

Pressione qualquer tecla para continuar...

Figura 8.34: Receptores Desempatados.

Sistena orion

Quarta, 28 de Janeiro de 1993

Considerando que

0 ponto referemte aos fatores prinarios e' 1 B

0 ponto referemte aos fatores secundarios $e^{\prime} 6$ E

0 ponto referente ans fatares terciarios $e^{j} 4,0$ E

Conbinando as pontos obten-se 11.8

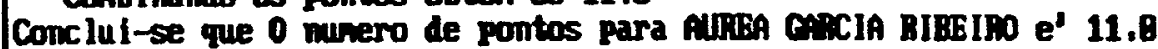

Quer que explique os considerandos dessas condicoes $(5 / n) 7$

As respostas ualidas sad: s para sin ou n para nad

Responda nowanzinte

Figura 8.35: Explicação de Como o Sistema chegou a uma Solução 


\section{Relatorio sobre o processo de alocacao}

Essa opção permite imprimir um relatório referente ao processo de alocação que foi efetuado, mostrando quais os receptores selecionados, quais aqueles que devem ser selecionados para Cross-Match, etc.

\subsection{Considerações Finais}

Neste capítulo foram mostrados alguns exemplos de interação do usuário com o sistema $\mathcal{O} \mathcal{R} \mathcal{I} \mathcal{N}$. Esses exemplos foram elaborados utilizando uma quantidade pequena de receptores, de modo a facilitar a compreensão.

Com esses exemplos, foi possivel perceber que a interface utilizada pelo Sistema Baseado em Conhecimento é mais simples daquela utilizada pelo Sistema de Base de Dados. Essa e outras dificuldades encontradas no decorrer do desenvolvimento do sistema $\mathcal{O R I O N}$ - principalmente quanto aos softwares disponiveis na Universidade - serão descritas com maiores detalhes capítulo seguinte. 


\section{Capítulo 9}

\section{Conclusões}

\subsection{Considerações Iniciais}

Este capítulo conclui esta dissertação, descrevendo algumas considerações sobre o sistema $\mathcal{O R I O N}$. São mostradas, também, sugestões para a continuidade do trabalho aqui efetuado.

\subsection{Considerações sobre o SBD}

Embora o desenvolvimento do Sistema de Base de Dados tenha sido efetuado na versão mais recente de um dos mais difundidos "SGBD" para microcomputadores, foi realmente trabalhoso e algo que consumiu muito tempo a elaboração das telas, gráficos e relatórios.

Além desse fato, e por motivos de segurança, foi necessária a construção do módulo de criptografia de senhas e outros dados dos usuários do sistema em linguagem $\mathbf{C}$. Isto foi devido ao baixo desempenho no tempo de resposta que foi obtido com a utilização da linguagem DBase III.

A linguagem utilizada também não é capaz de elaborar gráficos. Sendo assim, dois gráficos foram construidos utilizando-se caracteres especiais, sem utilizar o modo gráfico do monitor de vídeo. Outro gráfico foi elaborado utilizando-se a linguagem Pascal, compilando-se com o Turbo Pascal 5.5 da Borland para geração do código executável. Nesse último caso, foi necessária mais uma interface que fosse capaz de transferir os dados do DBase III para Pascal. 
Salienta-se que o principal motivo da escolha dos compiladores, tanto para o SBD como para o SBC, foi devido à disponibilidade desses softwares. Entretanto, é tempo de centros de pesquisa como a Universidade de São Paulo adquirir softwares de boa qualidade que permitam, ao pesquisador, utilizar seu tempo realmente em pesquisas e não em esforços desnecessários devido a limitações de software.

\subsection{Considerações sobre o SBC}

É realmente muito difícil encontrar um Núcleo de Sistema Especialista que seja perfeitamente adequado aos requisitos de uma aplicação específica. Geralmente, os núcleos existentes comercialmente - denominados Shells - são restritos, não apresentando características importantes no desenvolvimento de sistemas.

Por outro lado, a existência de um núcleo que possua todas essas caracteríticas pode tornar a aplicação demasiadamente lenta, supondo que ela não utilize todas a facilidades oferecidas. Isso é devido ao fato de não ser possível remover os códigos redundantes em um núcleo fechado.

Portanto, é interessante ao projetista de um Sistema Baseado em Conhecimento e, conseqüentemente de um Sistema Especialista, que o núcleo seja flexível o suficiente para se adequar ao problema que deve solucionar. Isso pode ser obtido desenvolvendo-se um núcleo composto por módulos que possam ser alterados, modificados ou substituídos por outros.

O Ambiente descrito em [Monard 91,Rodrigues 90a] possui as características acima mencionadas. Entretanto, é necessário salientar que para trabalhos voltados para uso profissional não faz sentido utilizar um ambiente desenvolvido e destinado à pesquisa, devido a existência de uma interface muito simples com o usuário, basicamente textual.

Com relação ao software Arity Prolog 6.0, no qual o SBC de ORION foi escrito, ele é composto de um interpretador e um compilador de código fonte Prolog. $O$ compilador, utilizado para gerar o código executável, apresenta problemas quando se utiliza "dialog boxes" e outros objetos de manipulação de tela.

Além desse fato, a manipulação desse objetos visuais não é nada trivial. Por essa razão, foi utilizada uma interface que não fizesse uso desses objetos, de forma a permitir o uso do compilador e não apenas do interpretador. 


\subsubsection{Ferramentas}

Sem dúvida, o processo de desenvolvimento dos Sistemas Baseados em Conhecimento é consideravelmente facilitado com a utilização de linguagens como Prolog e LISP, pois oferecem suporte a uma grande variedade de estruturas de dados e de controle.

Entretanto, atualmente, a maioria dos SBCs são construídos utilizando alguma ferramenta de Engenharia de Conhecimento - as Ferramentas de Apoio e os Shells - reduzindo ainda mais o tempo necessário para o desenvolvimento desses sistemas.

As Ferramentas de Apoio oferecem vários esquemas de representação de conhecimento, motor de inferência, estratégia para resolução de problemas, interfaces para aquisição de conhecimento e explicação de conclusões.

Os Shells são mais restritos, pois a interface e a estratégia para resolução de problemas são pré-fixadas, não podendo ser modificadas. Geralmente, os esquemas de representação de conhecimento e motor de inferência podem ser alterados.

Conforme [Rodrigues 93], os Shells são usados para resolver uma classe específica de problemas e não possuem a flexibilidade e a generalidade encontradas nas Ferramentas de Apoio, que permitem, ao Engenheiro de Conhecimento, definir seus próprios mecanismos de controle. Mesmo sendo mais restritos, os Shells tendem a ser mais simples e fáceis de serem usados do que as Ferramentas de Apoio.

Alguns exemplos de ferramentas de suporte à construção de Sistemas Baseados em Conhecimento, seus respectivos distribuidores e preços (em US\$) são fornecidos na Tabela 9.1 [Mattos 91].

\begin{tabular}{|c|c|r|}
\hline Ferramenta & Distribuidor & Preço \\
\hline ART & Inference & 65.000 \\
\hline BABYLON & GMD & 3.000 \\
\hline KEE & Intellicorp & 50.000 \\
\hline $\begin{array}{c}\text { Knowledge } \\
\text { Craft }\end{array}$ & $\begin{array}{c}\text { Carnegie } \\
\text { Group }\end{array}$ & 50.000 \\
\hline LOOPS & XEROX & 15.000 \\
\hline
\end{tabular}

\begin{tabular}{|c|c|r|}
\hline Shell & Distribuidor & Preşo \\
\hline INSIGHT & Level-5-R & 500 \\
\hline KES & Software A\&E & 4.000 \\
\hline MED2 & Inware & 15.000 \\
\hline $\begin{array}{c}\text { Nexpert } \\
\text { Object }\end{array}$ & Neuron Data & 4.000 \\
\hline Picon & LMI & 60.000 \\
\hline
\end{tabular}

Tabela 9.1: Ferramentas de Apoio e Shells 


\subsection{Trabalhos Futuros}

São apresentadas, nas seções seguintes, algumas sugestões de trabalhos que podem ser desenvolvidos com base nos resultados obtidos nesta dissertação.

\subsubsection{Extensões no Sistema de Base de Dados}

A seguir são apresentadas algumas sugestões para melhorias no SBD de $\mathcal{O} R \mathcal{I O N}$ :

- De acordo com o que foi citado na Seção 9.2, tudo colabora para que trabalhos futuros utilizem um Sistema Gerenciador de Base de Dados com maiores recursos para o desenvolvedor de sistemas, englobando facilidades de confecção de telas, relatórios e gráficos.

- Para os relatórios e gráficos esporádicos, é conveniente que o SGBD possua uma linguagem de consulta. Com isso, qualquer usuário pode extrair informações das Bases de Dados no formato desejado, sem que haja a necessidade de introduzir novos módulos com utilização pouco freqūente no sistema.

- Outro ponto importante é que o SGBD possa ser executado em diversas plataformas de hardware, possibilitando a migração de uma máquina para outra de forma mais simples.

- Com a utilização em maior escala das redes locais de computadores e com o surgimento das estações de trabalho, é muito importante que o Sistema Gerenciador de Base de Dados possua também, dentre algumas, as facilidades de controle de acesso concorrente aos dados, dicionário de dados ativo e transações atômicas [Elmasri 89].

- Devido ao fato do projeto do SBD estar documentado no Apêndice B, espera-se no futuro, dependendo do sucesso do sistema, transportá-lo para um SGBD apropriado, ou seja, com as características citadas nos itens anteriores. 


\subsubsection{Extensões no Sistema Baseado em Conhecimento}

Com relação ao Sistema Baseado em Conhecimento, pode-se sugerir que:

- O núcleo desenvolvido em [Rodrigues 90a] foi de grande utilidade para ve rificar e validar as regras de conhecimento. Esse ambiente também permite que se aprenda como um núcleo de SBC realmente trabalha, permitindo avaliar com maior facilidade os núcleos comercialmente existentes. Entretanto, é de fundamental importância que o SBC existente em $O R I O \mathcal{N}$ seja reescrito utilizando um bom núcleo comercial, principalmente para obter-se uma interface profissional com o usuário [Rodrigues 93].

- Mesmo utilizando-se o ambiente de [Rodrigues 90a], algumas melhorias podem ser efetuadas - ainda ressaltando que a solução apropriada consiste no uso de um sistema profissional:

- Quando disponivel uma versão do compilador Arity Prolog que aceite a utilização de objetos visuais, tais como "dialog boxes", seria conveniente alterar a atual interface com o usuário;

口 Uma interface gráfica (Microsoft Windows ou IBM OS/2) poderá ser utilizada de forma a proporcionar ao usuário um meio mais amigável de usar o sistema;

- Implementação de uma interface no SBC que permita alterar e introduzir novas regras de conhecimento em linguagem natural. Atualmente, essas inclusões e alterações devem ser efetuadas por um editor de texto e em linguagem Prolog. Todavia, é necessário não somente um conhecimento prático da linguagem [Monard 93a,Monard 93b] mas há determinados aspectos teóricos de Prolog que também devem ser conhecidos para usá-la apropriadamente [Nicoletti 93].

- Em trabalhos posteriores, seria altamente conveniente que se utilizasse ferramentas que auxiliassem durante o processo de aquisição e estruturação do conhecimento. No presente trabalho, embora pareçam simples, essas fases foram realmente trabalhosas.

\subsection{Consideraçōes Finais}

Apesar da grande discrepância existente entre a tecnologia brasileira, tanto em hardware como em software, e a de países do Primeiro Mundo - o que dificulta a 
realização de trabalhos em áreas de pesquisas como em Ciência da Computação, onde as evoluções ocorrem rapidamente - os pesquisadores universitários têm conseguido contornar essa situação, com esforços muitas vezes desnecessários e descomunais, para desenvolver softwares que atendam suas necessidades.

Entretanto, isso é obtido somente através de um grande trabalho computacional pelo simples motivo de utilizar-se o que se tem e não necessariamente o que seja mais apropriado. Seria realmente muito nobre e engrandecedor para o pesquisador - e para a cumunidade para qual ele desenvolve suas pesquisas - se fossem fornecidos a ele os recursos necessários para poder trabalhar com softwares de primeira qualidade. 


\section{Referências}

[Alty 84] Alty, A.L. and Coombs, M.J. "Expert Systems - Concepts and Examples". NCC Publications, 1984.

[Arity 90] Arity Corporation. "The Arity/Prolog Programming Language". CSA Press, Massachussets, 1990.

[Ávila 91] Ávila, B.C. "Representação de Conhecimento Utilizando Frames". Tese de Mestrado, ICMSC-USP, 1991.

[Ávila 92] Ávila, B.C. e Monard, M.C. "SEMARF: Um Sistema para Manipular Frames". Notas do ICMSC-USP, № 111, Maio 1992.

[Bachanan 85] Bachanan, B.G. and Shortliffe, E.H. "Rule-Based Expert Systems: The MYCIN Experiments of the Stanford Heuristic Programming Project". Addison-Wesley, 1985.

[Brachman 88] Brachman, R.J. "The Basics of Knowledge Representation and Reasoning". AT\&T Technical Journal, Vol. 67, Issue 1, Jan-Feb. 1988, pp. 7-24.

[Braga 88] Braga, J.L. e Melo, R.N. "Sistemas para Gerenciamento de Bases

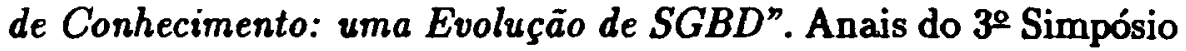
Brasileiro de Banco de Dados, 1988, pp. 180-190.

[Bramer 82] Bramer, M.A. "A Survey and Critical Review of Expert Systems Research". Introductory Readings in Expert Systems, Michie, D. (ed.), University of Edinburgh, 1982, pp. 3-29.

[Bratko 90] Bratko, I. "Prolog Programming for A.I.". Addison-Wesley, 2 Edition, 1990.

[CA 90] Computer Associates. "Computing Architecture for the 90s". Computer Associates International, Inc., 1990. 
[Cameron 86] Cameron, J.R. "An Overview of JSD". IEEE Transactions on Software Engineering, Vol. SE-12, № 2, Feb. 1986, pp. 222-240.

[Cameron 89] Cameron, J.R. "JSP and JSD: The Jackson Approach to Software Development”. IEEE Computer Society Press, $2^{\frac{n d}{d}}$ Edition, 1989.

[Carroll 88] Carroll, D.W. "Programação em Turbo Pascal". McGraw-Hill, 1988.

[Chen 76] Chen, P.P. "The Entity-Relationship Model - Toward a Unified View of Data". ACM Transactions on Database Systems, Vol. 1, № 1, Mar. 1976, pp. 9-36.

[Clocksin 87] Clocksin, W.F. and Mellish, C.S. "Programming in Prolog". Springer Verlag, $3^{\text {rd }}$ Edition, 1987.

[Date 86] Date, C.J. "Introdução a Sistemas de Bancos de Dados". Editora Campus, 4⿳亠丷厂 Edição, 1986.

[Davis 90] Davis, W.S. "Sistemas Operacionais: uma Visão Sistemática". Editora Campus, $3^{\text {a }}$ Edição, 1990, pp. 64-69.

[Debenham 89] Debenham, J.K. "Knowledge Systems Design”. Prentice Hall, 1989.

[DISCO 90] "Design and Implementation of Symbolic Computation Systems". In Proc. International Symposium DISC0'90, Capri (Italy), Apr. 1990, in Lecture Notes in Computer Science, Miola, A. (ed.), Springer Verlag, Vol. 429, 1990.

[EAIA 90] Proc. Natural Language Processing EAIA'90, $2^{\text {nd }}$ Advanced School in AI, Guarda (Portugal), Oct. 1990, in Lecture Notes in Computer Science, Filgueiras, M.; Damas, L.; Moreira, N. and Tomás, A.P. (eds.), Springer Verlag, Vol. 476, 1991.

[Elmasri 89] Elmasri, R. and Navathe, S.B. "Fundamentals of Database Systems". The Benjamin/Cummings Publishing Company, Inc., 1989.

[EWSP 91] Proc. European Workshop on Planning EWSP'91, Sankt Augustin (FRG), Mar. 1991, in Lecture Notes in Computer Science, Hertzberg, J. (ed.), Springer Verlag, Vol. 522, 1991.

[Ford 87] Ford, N. "How Machines Think: A General Introduction to Artificial Intelligence”. John Wiley \& Sons, 1987. 
[Franco 91] Franco, J.L. "Sobre Avaliação Parcial de Meta-Interpretadores e Geração de Núcleos Específicos de Sistemas Especialistas". Tese de Mestrado, ICMSC-USP, 1991.

[Franco 92] Franco, J.L. e Monard, M.C. “Avaliação Parcial de Programas Prolog e sua Utilização na Meta-Programação." Série C\&T do ILTC, Vol. 1, № 13, Novembro 1992.

[Freundlich 90] Freundlich, Y. "Knowledge Bases and Databases - Converging Technologies, Diverging Interests”. Computer, Vol. 23, № 11, Nov. 1990, pp. 51-57.

[Gabriel 85] Gabriel, R. "Postgraduate Nephrology". Butterworths, $3^{\text {rd }}$ Edition, 1985.

[Gilks 91] Gilks, W.R.; Gore, S.M. and Bradley, B.A. "Predicting Match Grade and Waiting Time to Kidney Transplantation". Transplantation, Vol. 51, № 3, Mar. 1991, pp. 618-624.

[Grahne 91] Grahne, G. "The Problem of Incomplete Information in Relational Databases". In Lecture Notes in Computer Science, Springer Verlag, Vol. 554, 1991.

[Gray 89a] Gray, P.M.D. "Integration of Databases and Expert Systems through Prolog". Perspectives in Artificial Intelligence, Campbell, J.A. and Cuena, J. (eds.), Ellis Honwoud Limited and John Wiley \& Sons, Vol. 2, 1989.

[Gray 89b] Gray, P.M.D.; Archibald, I.G. and Lunn, K. "Interfacing a Knowledge-Based System to a Large Database". The Knowledge Engineering Review, Vol. 4, № 1, 1989, pp. 31-51.

[Halasz 91] Halasz, N.A. "Medicine and Ethics - How to Allocate Transplantable Organs”. Transplantation, Vol. 52, № 1, Jul. 1991, pp. 43-46.

[Harris 87] Harris, L.R. "The Marriage of AI and Data Base Technology". AI Expert, Mar. 1987, pp. 7-8.

[Hayes-Roth 84] Hayes-Roth, F. “The Knowledge-Based Expert System: A Tutorial". Computer, Sep. 1984, pp. 11-28.

[Hayes-Roth 87] Hayes-Roth, F. "Rule-Based Systems". Encyclopedia of Artifcial Intelligence, Shapiro, S.C. (ed.), John Wiley \& Sons Inc., Vol. 2, 1987, pp. 963-973. 
[Hikita 85] Hikita, S.; Kawakami, S. and Haniuda, H. "Database Machine FREND". Database Machines - Fourth International Workshop, Mar. 1985, pp. 190-207.

[Hohne 87] Hohne, B. and Pierce, T. "Chemistry, AI in". Encyclopedia of Artificial Intelligence, Shapiro, S.C. (ed.), John Wiley \& Sons Inc., Vol. 1, 1987, pp. 93-99.

[Howard 89] Howard, H.C. and Rehak, D.R. “KADBASE - Interfacing Expert Systems with Databases". IEEE Expert, Fall 1989, pp. 65-76.

[Kellogg 86] Kellog, C. "From Data Management to Knowledge Management". Computer, Jan. 1986, pp. 75-84.

[Kernighan 88] Kernighan, B.W. and Ritchie, D.M. "The C Programming Language”. Prentice Hall, $2^{\text {nd }}$ Edition, 1988.

[Klahr 86] "Expert Systems: Techniques, Tools and Applications". Klahr, P. and Waterman, D.A. (eds.), Addison-Wesley, 1986.

[Lecot 86] Lecot, K. and Parker, D.S. “Control Over Inexact Reasoning”. AI Expert, 1986, pp. 32-43.

[Leland 85] Leland, M.D.P. and Roome, W.D. "The Silicon Database Machine". Database Machines - Fourth International Workshop, Mar. 1985, pp. 169-189.

[Leone 92] Leone, F.A; Degrève, L. and Baranauskas, J.A. "SIGRAF A Versatile Computer Program for Fitting Enzyme Kinetic Data". Biochemical Education, 20(2), 1992, pp. 94-96.

[Leung 90] Leung, K.S. and Wong, M.H. "An Expert-System Shell using Structured Knowledge". Computer, Mar. 1990, pp. 38-47.

[Manninen 85] Manninen, D.L. and Evans, R.W. "Public Attitudes and Behavior Regarding Organ Donation”. JAMA, № 21, Vol. 253, Jun. 7, 1986, pp. 3111-3115.

[Martin 86] Martin, D. “Advanced Database Techniques”. The MIT Press, 1986.

[Masiero 88] Masiero, P.C. e Penteado, R.A.D. “Desenvolvimento Sistemático de Sistemas de Informação: A Abordagem JSD”. ICMSC-USP, 1988. 
[Masiero 92] Masiero, P.C. “Análise Estruturada de Sistemas pelo Método de Jackson”. Edgard Blucher Ltda, 1992.

[Mattos 90a] Mattos, N. "An Approach to DBS-based Knowledge Management". In Proc. First Workshop on Information Systems and Artificial Intelligence: Integration Aspects, Ulm (Germany), Mar. 1990, in Lecture Notes in Computer Science, Karagiannis, D. (ed.), Springer Verlag, Vol. 474, 1991, pp. 127-152,.

[Mattos 90b] Mattos, N. "Performance Measurements and Analyses of Coupling Approaches of Databases and Expert Systems and Consequences to their Integration". In Proc. First Workshop on Information Systems and Artificial Intelligence: Integration Aspects, Ulm (Germany), Mar. 1990, in Lecture Notes in Computer Science, Karagiannis, D. (ed.), Springer Verlag, Vol. 474, 1991, pp. 283-288.

[Mattos 91] Mattos, N. "An Approach to Knowledge Base Management". In Lecture Notes in Computer Science, Siekmann, J. (ed.), Springer Verlag, Vol. 513, 1991.

[Menezes Filho 88] Menezes Filho, A.; Sette, S.S.; Florissi, D. e Soares, P.G. "Proposta de um Linguagem de Restrição de Dados". Anais do 3o Simpósio Brasileiro de Banco de Dados, 1988, pp. 62-72.

[Miola 91] Miola, A. "Symbolic Computation and Artificial Intelligence". In Proc. International Workshop on Fundamentals of Artificial Intelligence Research, Smolenice (Czechoslovakia), Sep. 1991, in Lecture Notes in Artificial Intelligence, Jorrand, P. and Kelemen, J. (eds.), Springer Verlag, Vol. 535, 1991, pp. 244-255.

[Monard 89a] Monard, M.C. e Prado, A.H.A. "Uso de Incerteza em Sistemas Baseados em Conhecimento". ILTC, Maio 1989.

[Monard 89b] Monard, M.C. e Rodrigues, S.R. "Implementação Lógica de um Motor de Inferência com Raciocínio Backward Chaining para a Construção de um Sistema Especialista”. Notas do ICMSC-USP, № $51,1989$.

[Monard 89c] Monard, M.C. e Rodrigues, S.R. "Desenvolvimento de Sistemas Especialistas em Prolog”. ILTC, Julho, 1989.

[Monard 91] Monard, M.C. and Rodrigues, S.R. “An Environment for Developing Expert Systems Shells". The World Congress on Expert Systems, Orlando, Florida USA, 1991. 
[Monard 93a] Monard, M.C. e Nicoletti, M.C. "Programas Prolog para Processamento de Listas e Aplicações". Notas Didáticas do ICMSC-USP, № 7, Janeiro 1993.

[Monard 93b] Monard, M.C. e Nicoletti, M.C. "Técnicas Avançadas de Programação Prolog para Tratamento de Árvores". Notas Didáticas do ICMSC-USP, № 8, Fevereiro 1993.

[Nau 83] Nau, D.S. “Experts Computer Systems”. Computer, Vol. 16, № 2, Feb. 1983, pp. 63-85.

[Ng 90] $\mathrm{Ng}, \mathrm{K}$. and Abramson, B. "Uncertainty Management in Expert Systems". IEEE Expert, Apr. 1990, pp. 29-48.

[Nicoletti 93] Nicoletti, M.C. and Monard, M.C. "Herbrand Interpretation, Model and Least Model within the Framework of Logic Programming". Notas do ICMSC-USP, Série Computação, № 002, Junho 1993.

[Opelz 88] Opelz, G. "The Benefit of Exchanging Donor Kidneys among Transplant Centers". The New England Journal of Medicine, Vol. 318, № 20, May 1988, pp. 1289-1292.

[Payne 90] Payne, E.C. and McArthur, R.C. "Developing Expert Systems: A Knowledge Engineer's Handbook for Rules 8 Objects". John Wiley \& Sons, 1990.

[Pressman 87] Pressman, R.S. “Software Engineering: A Practitioner's Approach". McGraw-Hill, 2 ${ }^{\text {nd }}$ Edition, 1987.

[Ramalho 91] Ramalho, J.A. "Clipper 5.0”. McGraw-Hill, Vol.1, 1991.

[Rennels 87] Rennels, G. and Shortliffe, E. “Medical Advice Systems". Encyclopedia of Artificial Intelligence, Shapiro, S.C. (ed.), John Wiley \& Sons Inc., Vol. 1, 1987, pp. 584-591.

[Renold 88] Renold, A. “Jackson System Development for Real Time Systems". Scientia Eletrica, Vol. 34, № 2, 1988, pp. 3-43.

[Rich 87] Rich, E. "Artificial Intelligence”. Encyclopedia of Artificial Intelligence, Shapiro, S.C. (ed.), John Wiley \& Sons Inc., Vol. 1, 1987, pp. 9-16.

[Rich 88] Rich, E. "Inteligência Artificial”. McGraw-Hill, São Paulo, 1988.

[Richards 88] Richards, B.L. "When Facts Get Fuzzy". Byte, Apr. 1988, pp. 285290. 
[Rodrigues 89] Rodrigues, S.R. e Monard, M.C. “Um Subsistema de um Núcleo de Sistema Especialista para Interrogar o Usuário Admitindo Diversas Categorias de Perguntas”. Anais do 60 Simpósio Brasileiro em Inteligência Artificial, 1989, pp. 78-93.

[Rodrigues 90a] Rodrigues, S.R. "Um Ambiente para Auxiliar a Construção de Núcleos de Sistemas Especialistas". Tese de Mestrado, ICMSCUSP, 1990.

[Rodrigues 90b] Rodrigues, S.R. e Monard, M.C. "Implementação Lógica de um Módulo Coletor de Dados para a Construção de Sistemas Especialistas". Notas do ICMSC-USP, № 63, 1990.

[Rodrigues 90c] Rodrigues, S.R. e Monard, M.C. “Uso de Metn-Interpretadores no Desenvolvimento de Núcleos de Sistemas Especialistas". ILTC, Agosto 1990.

[Rodrigues 93] Rodrigues, S.R. e Monard, M.C. "Sistemas Baseados em Conhecimento: Conceitos Fundamentais e Aplicações”. A ser publicado nos Anais CONDEX/SUCESU, São Paulo, SP, Agosto 1993.

[Sagan 85] Sagan, C. "Cosmos". Francisco Alves Editora, Rio de Janeiro, 1985.

[Sawaki 91] Sawaki, J. "Um Sistema Baseado em Conhecimento para Apoio aos Usuários da Biblioteca NAG". Tese de Mestrado, ICMSC-USP, 1991.

[Schildt 87] Schildt, H. “Advanced Modula-2". Osborne-McGraw Hill, 1987, pp. 213-250.

[Scholl 87] Scholl, M. et al. "VERSO: A Database Machine Based on Nested Relations". Nested Relations and Complex Objects in Databases in Lecture Notes in Computer Science, A biteboul, S.; Fischer, P.C. and Schek, H.-J. (eds.), Springer Verlag, Vol. 361, 1987, pp. 27-49.

[Schur 88] Schur, S. “The Intelligent Database”. AI Expert, Jan. 1988, pp. 26-34.

[Sciore 88] Sciore, E. and Warren, D.S. "Integrating Data Bases \& Prolog". AI Expert, Jan. 1988, pp. 38-43.

[Silva 90] Silva, E.C. e Braga, J.L. “Um Protótipo de Otimizador de Consultas a Banco de Dados Relacionais com Base de Conhecimento Multinivel". Anais do $5^{\circ}$ Simpósio Brasileiro de Banco de Dados, 1990, pp. 231-243. 
[Simpson 86] Simpson, A. "dBase III - Guia Completo". EBRAS, 1986.

[SPIT 89] "Protocolo São Paulo Interior Transplante". Hospital das Clínicas da Faculdade de Medicina de Ribeirão Preto - USP, Majo 1989.

[SPIT 91] "Protocolo São Paulo Interior Transplante". Hospital das Clínicas da Faculdade de Medicina de Ribeirão Preto - USP, Julho 1991.

[Starzl 87] Starzl, T.E. et al. "A Multifactorial System for Equitable Selection of Cadaver Kidney Recipients". JAMA, № 22, Vol. 257, Jun. 12, 1987, pp. 3073-3075.

[Stefik 82] Stefick M. et al. "The Organization of Expert Systems, A Tutorial". Artificial Intelligence, Vol. 18, 1982, pp. 135-173.

[Sterling 87] Sterling, L. and Shapiro, E. "The Art of Prolog". The MIT Press, 1987.

[Sutcliffe 88] Sutcliffe, A. “Jackson System Development”. Prentice Hall, 1988.

[Swartout 91] Swartout, W.; Paris, C. and Moore, J. "Design for Explainable Expert Systems". IEEE Expert, Jun. 1991, pp. 58-64.

[TCOTTS 86] The Council of the Transplantation Society. "Commencialization in Transplantation: The Problems and Some Guidelines for Practicen. Transplantation, Vol. 41, № 1, Jan. 1986, pp. 1-3.

[Thomas 90] Thomas, G. et al. "Heterogeneous Distributed Database Systems for Production Use”. ACM Computing Surveys, Vol. 22, № 3, Sep. 1990, pp. 237-266.

[Thompson 85] Thompson, B.A. and Thompson, W.A. "Inside an Expert System". Byte, Apr. 1985, pp. 315-330.

[Ullman 82] Ullman, J.D. "Principles of Database Systems". Computer Science Press, $2^{\text {nd }}$ Edition, 1982.

[Unland 90] Unland, R. and Sclageter, G. "Object Oriented Database Systems: Concepts and Perspectives". In Proc. International Symposium of IBM Germany on Database Systems of the 90s, Berlin (Germany), Nov. 1990, in Lecture Notes in Computer Science, Blaser, A. (ed.), Springer Verlag, Vol. 466, 1990, pp. 154-197.

[Waterman 86] Waterman, D.A. “A Guide to Expert Systems”. Addison-Wesley, 1986. 
[Wiederhold 84] Wiederhold, G. "Databases". Computer, Oct. 1984, pp. 211-223.

[Zobaidie 87] Zobaidie, A. and Grimson, J.B. "Expert Systems and Database Systems: How Can They Serve Each Other". Expert Systems, Vol. 4, № 1, Feb. 1987, pp. 30-37.

[Zadeh 83] Zadeh, L.A. "Commonsense Knowledge Representation Based on Fuzzy Logic”. Computer, Vol. 16, № 10, Oct. 1983, pp. 61-65. 


\section{Apêndice A}

\section{Siglas e Abreviaturas}

BC Base de Conhecimento.

BD Base de Dados.

CGA Color Graphics Adaptor.

e.g. Do latim exempli gratia (por exemplo).

EGA Enhanced Graphics Adaptor.

FMRP Faculdade de Medicina de Ribeirão Preto - USP.

GE General Eletric.

HCFMRP Hospital das Clínicas da Faculdade de Medicina de Ribeirão Preto - USP.

IA Inteligência Artificial.

IBM International Business Machines.

IDS Integrated Data Store.

IMS Information Management System.

PRA Panel Reactive Antibody number.

Prolog Programming in Logic.

SBC Sistema Baseado em Conhecimento. 
SBD Sistema de Base de Dados.

SPIT São Paulo Interior Transplante.

SPI Software Products International.

SQL/DS Structured Query Language/Data System.

USP Universidade de São Paulo. 


\section{Apêndice B}

\section{Projeto do Sistema de Base de Dados}

\section{B.1 Considerações Iniciais}

Com base nas informaçōes dos capítulos anteriores é possivel definir as informaçôes a serem colocadas no Sistema de Base de Dados contido em ORION. Para tanto, é adotado o método Jackson System Design - JSD - para o projeto do sistema [Cameron 89,Sutcliffe 88].

É conveniente salientar que uma descrição funcional de $\mathcal{O R I O N}$ foi descrita nos Capítulos 4 à 7 . $O$ modelo entidade-relacionamento - referente ao Sistema de Base de Dados de $O R I O N$ [Masiero 92] — foi mostrado na Figura 7.2, página 71.

Nas seções seguintes é suposto que o leitor tenha conhecimento desse método, contudo uma breve explicação de cada uma das suas etapas é fornecida, juntamente com o desenvolvimento do projeto do sistema $O R I O N$.

\section{B.2 Sobre JSD}

Em JSD, um sistema é visto da forma mostrada na Figura B.1 [Renold 88]. Os processos de entrada coletam dados do mundo real, verificam erros e os passam para os processos de modelagem, se estiverem corretos. Caso contrário, os dados são rejeitados. 


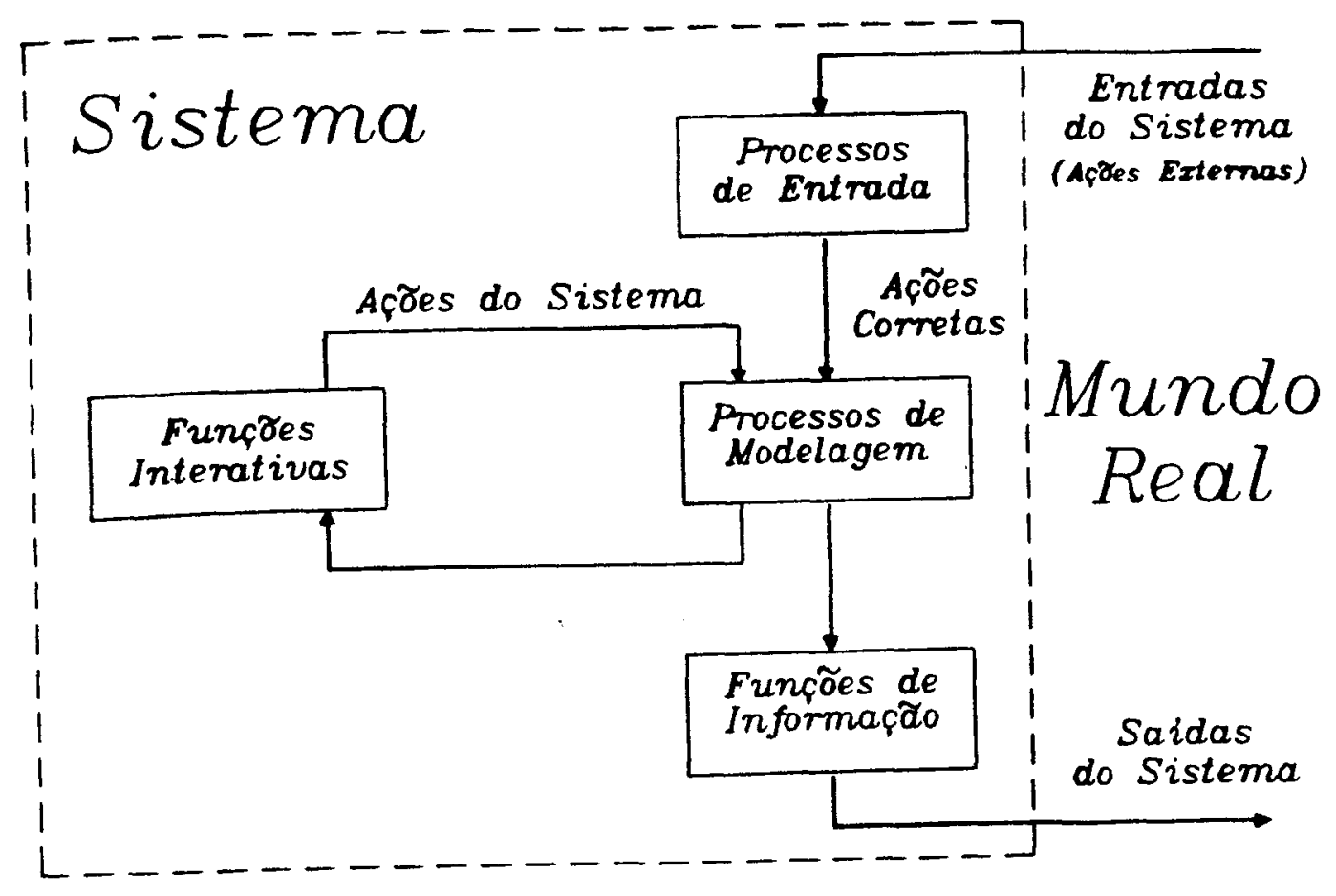

Figura B.1: JSD: Visão Geral

Os processos de modelagem modelam os processos correspondentes no mundo real dentro do sistema. Por exemplo, quando um cliente retira dinheiro de sua conta bancária, o processo de modelagem correspondente dentro do sistema deve subtrair a quantidade retirada.

Os processos funcionais, ou funções de informação, extraem informações do modelo de forma a obter as saídas necessárias ao mundo real. Exemplos típicos sâo os relatórios, gráficos, etc.

As funções interativas geram ações do sistema. As ações podem ser vistas como funções externas que são criadas pelo próprio sistema. Em muitos casos, essas funções necessitam de informações do modelo para gerar novas ações. Desse modo, as funçôes interativas são como processos funcionais, exceto que elas produzem entradas para o sistema ao invés de saídas.

Exemplificando, um sistema de gerenciamento de contas bancárias, após ter recebido um número determinado de cheques sem fundos de um mesmo cliente, pode cancelar seu cartão especial. Nesse caso, o bancário não informou diretamente ao sistema que o cartão especial do cliente em questão deveria ser cancelado. Foi o próprio sistema que se encarregou de realizar essa ação. 
Esses processos, mostrados na Figura B.l, não são obtidos de uma só vez. Ao invés, eles são construídos durantes as seguintes fases do método:

- Escolha das Entidades e Ações;

- Estruturação Cronológica das Ações;

- Construção do Modelo Inicial;

- Adição de Funções;

- Articulação Temporal dos Componentes do Sistema e

- Projeto da Implementação do Sistema.

Segue-se uma decrição de cada uma das fases.

\section{B.3 Escolha das Entidades e Ações}

Nesta etapa, determina-se a abrangência do sistema: quais os aspectos do mundo real que serão ou não considerados pelo sistema. Segundo [Masiero 88]:

...os limites do sistema são definidos pela escolha de entidades relevantes dentro do ambiente do problema. Essas entidades são pessoas ou coisas do mundo real que interagem através de açôes que elas executam ou sofrem ...

Os conceitos de entidade e de ação, fundamentais em JSD, são definidos como:

Uma entidade significa algum objeto real ou abstrato do ambiente do problema. As entidades executam ou sofrem ações, modificando, dessa forma, a situação do ambiente.

Os três critérios abaixo, em ordem de importância, auxiliam a identificar as entidades:

- Sofrer ou executar ações, dentro de uma certa ordem cronológica; 
- Ter existência no mundo real e não apenas dentro do Sistema de Informação em desenvolvimento e

- Ter identidade própria.

As ações possuem também certas características que facilitam a sua identificação. Pela ordem de importância, elas são:

- Ser instantânea;

- Ocorrer no mundo real e não apenas dentro do sistema e

- Não ser decomponível em subações.

No sistema SPIT, foram identificadas as seguintes entidades:

- Receptor;

- Suspensão de Receptor;

- Doador;

- Hospital;

- Suspensão de Hospital;

- Transplante.

Pelas definições anteriores, é claro que Receptor, Doador e Hospital são entidades, no contexto de $\mathcal{O} \mathcal{L} \mathcal{}$ N . Tanto Suspensão de Receptor, Suspensão de Hospital e Transplante poderiam ser considerados como ações de Receptor ou Doador. Entretanto, eles foram escolhidos como entidades, pois o sistema deverá ser capaz de responder questões do tipo:

- Quais as suspensões impostas a um determinado hospital ?

- Quantos transplantes um determinado receptor rejeitou ?

- Quais são os pacientes que já foram suspensos ? etc...

As ações das entidades selecionadas são mostradas na Tabela B.1. A seguir, são descritas a ações das entidades selecionadas. 


\begin{tabular}{|l|l|}
\hline ENTIDADE & AÇĀO \\
\hline \hline Hospital & $\begin{array}{l}\text { Cadastrar } \\
\text { Desligar }\end{array}$ \\
\hline $\begin{array}{l}\text { Suspensão } \\
\text { de Hospital }\end{array}$ & $\begin{array}{l}\text { Suspender } \\
\text { Retornar }\end{array}$ \\
\hline Receptor & $\begin{array}{l}\text { Cadastrar } \\
\text { Renovar soro } \\
\text { Desligar }\end{array}$ \\
\hline $\begin{array}{l}\text { Suspensão } \\
\text { de Receptor }\end{array}$ & $\begin{array}{l}\text { Suspender } \\
\text { Retornar }\end{array}$ \\
\hline Doador & $\begin{array}{l}\text { Cadastrar } \\
\text { Desligar }\end{array}$ \\
\hline Transplante & $\begin{array}{l}\text { Transplantar } \\
\text { Perder } \\
\text { Morrer }\end{array}$ \\
\hline
\end{tabular}

Tabela B.1: Entidades e Ações do Sistema ORION

Entidade B.3.1 Hospital

- CADASTRAR: o hospital é cadastrado no sistema.

ATRIBUTOS: número do hospital, razão social, tipo do hospital, grupo de hospitais a que pertence, fone, endereço, pessoa para contato e cidade.

- DESLIGAR: o hospital é desligado do sistema. ATRIBUTOS: número do hospital.

Entidade B.3.2 Suspensão de Hospital

- SUSPENDER: o hospital é suspenso, impedindo que seus pacientes participem do processo de seleção para transplante até a retirada da suspensão. ATRIBUTOS: número do hospital, data e motivo da suspensão.

- RETORNAR: retirada da suspensão do hospital. ATRIBUTOS: número do hospital, data do retorno. 


\section{Entidade B.3.3 Receptor}

- CADASTRAR: o receptor é cadastrado no sistema. ATRIBUTOS: número SPIT, nome, endereço, cidade, hospital, data de nascimento, data de cadastro, sexo, cor, data do soro recente, data do soro que forneceu o maior PRA, grupo $A B O, R h, H L A$, número de gestações, data de início da hemodiálise, número de transfusões, número de retransplantes, urgência médica.

- RENOVAR SORO: o soro é renovado.

ATRIBUTOS: número do receptor, data do soro recente.

- DESLIGAR: receptor é desligado do sistema.

ATRIBUTOS: número do receptor, data e motivo da saída

Entidade B.3.4 Suspensão de Receptor

- SUSPENDER: o paciente é suspenso do processo de alocação para transplante até a retirada da suspensão.

ATRIBUTOS: número do receptor, data e motivo da suspensão.

- RETORNAR: retirada da suspensão do receptor. ATRIBUTOS: número do receptor, data do retorno.

\section{Entidade B.3.5 Doador}

- CADASTRAR: o doador é cadastrado no sistema.

ATRIBUTOS: número do doador, grupo $A B O, R h, H L A$, cor, sexo, idade, causa morte, data da nefrectomia, hora nefrectomia, tempo de isquemia quente, número de orgãos, cidade de origem.

- DESLIGAR: o doador é retirado do sistema, devido a algum problema. ATRIBUTOS: número do doador.

\section{Entidade B.3.6 Transplante}

- TRANSPLANTAR: o transplante é efetuado.

ATRIBUTOS: número do doador, número do receptor, diurese do receptor, número de receptores aguardando por transplante com compatibilidade $A B O$ com o doador. 
- PERDER: o transplante é rejeitado pelo receptor.

ATRIBUTOS: número do doador, número do receptor, data da perda, causa.

- MORRER: o receptor morre com o transplante.

ATRIBUTOS: número do doador, número do receptor, data, causa.

\section{B.4 Estruturação Cronológica das Ações}

No mundo real, as ações ocorrem dentro de uma ordem cronológica. Nessa etapa do método, as ações executadas, ou sofridas, pelas entidades são colocadas em ordem cronológica de acordo com o mundo real. Os textos estruturados, referentes às entidades, são mostrados a seguir. Os diagramas de estrutura cronológica podem ser vistos nas Figuras B.2, B.3, B.4, B.5, B.6 e B.7.

Estrutura Cronológica B.4.1 Hospital

HOSPITAL seqūência

CADASTRAR;

DESLIGAR;

HOSPITAL fim

Estrutura Cronológica B.4.2 Suspensão de Hospital

SUSPENSÃO DE HOSPITAL iteração

SUSPENDER;

RETORNAR;

SUSPENSÃO DE HOSPITAL fim

Estrutura Cronológica B.4.3 Receptor

RECEPTOR seqüência

CADASTRAR;

RENOVAÇÃO-SORO iteração

RENOVAR;

RENOVAÇÃO-SORO fim

DESLIGAR;

RECEPTOR fim 


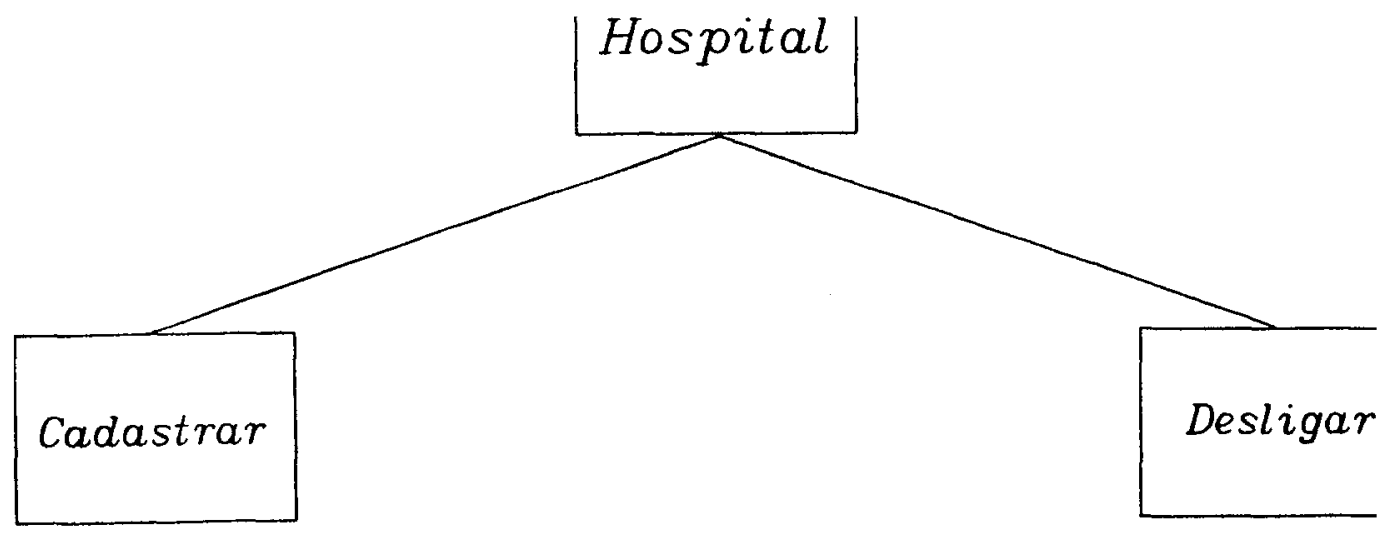

Figura B.2: Hospital: Diagrama de Estrutura Cronológica

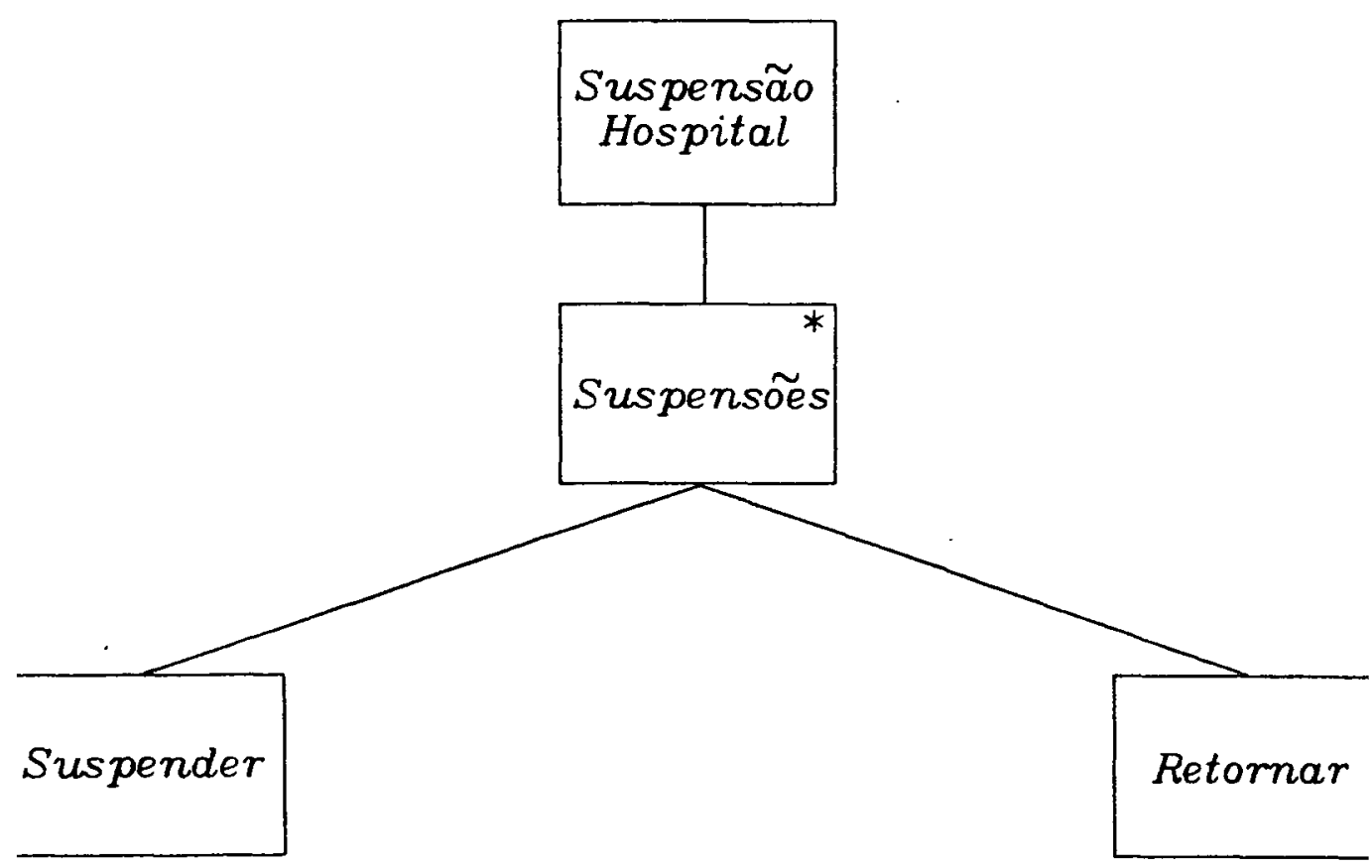

Figura B.3: Suspensão de Hospital: Diagrama de Estrutura Cronológica 


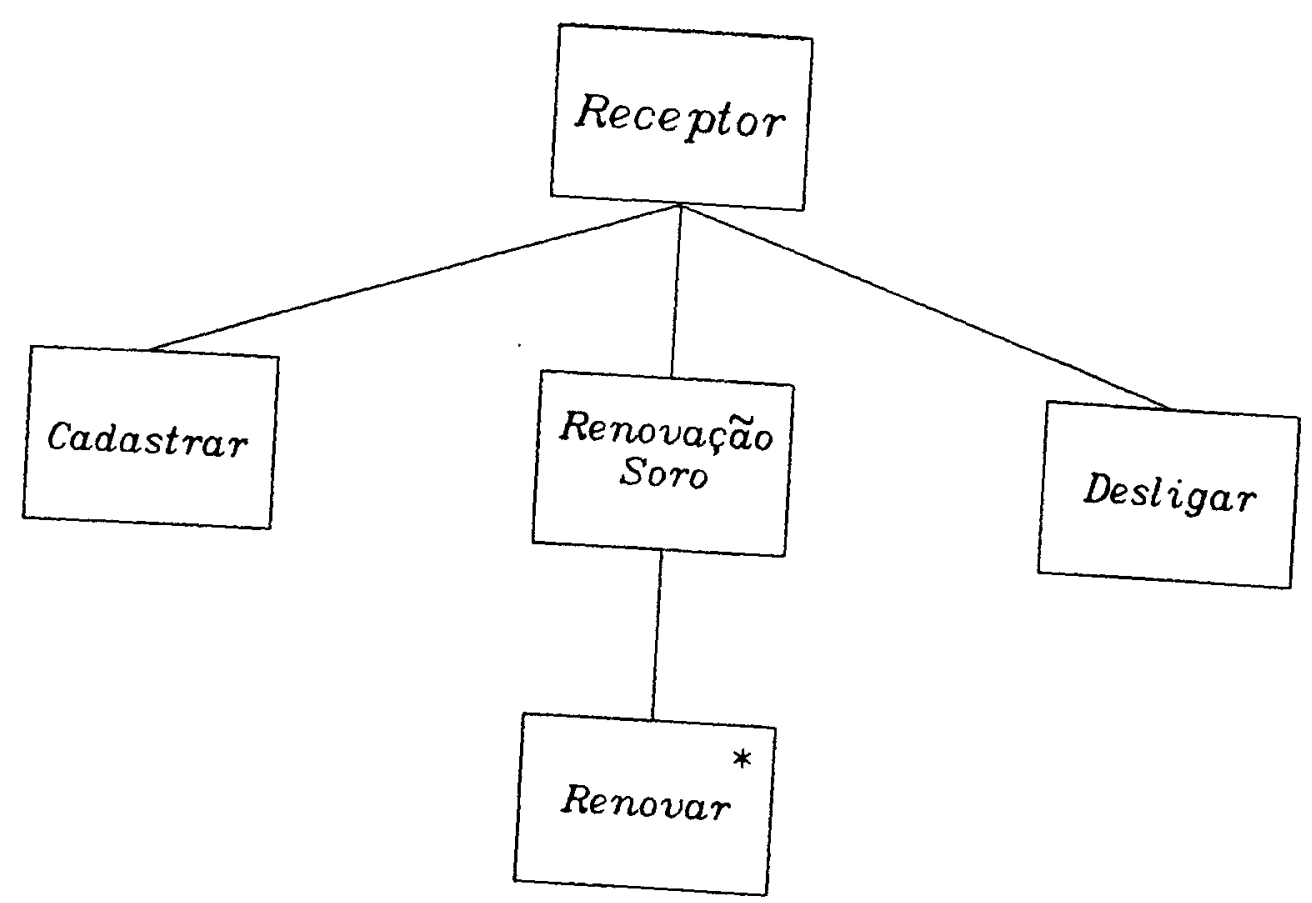

Figura B.4: Receptor: Diagrama de Estrutura Cronológica

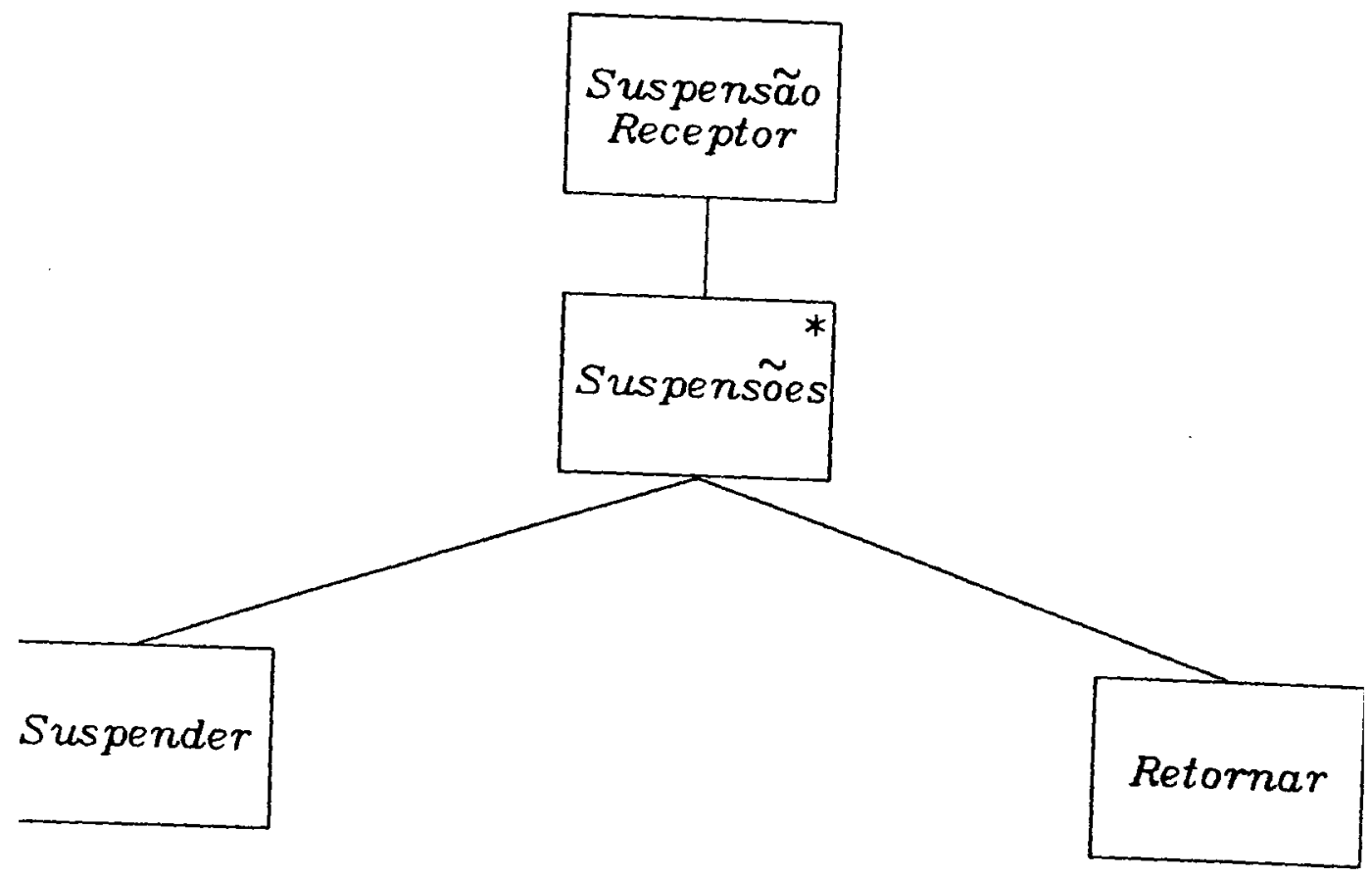

Figura B.5: Suspensão de Receptor: Diagrama de Estrutura Cronológica 


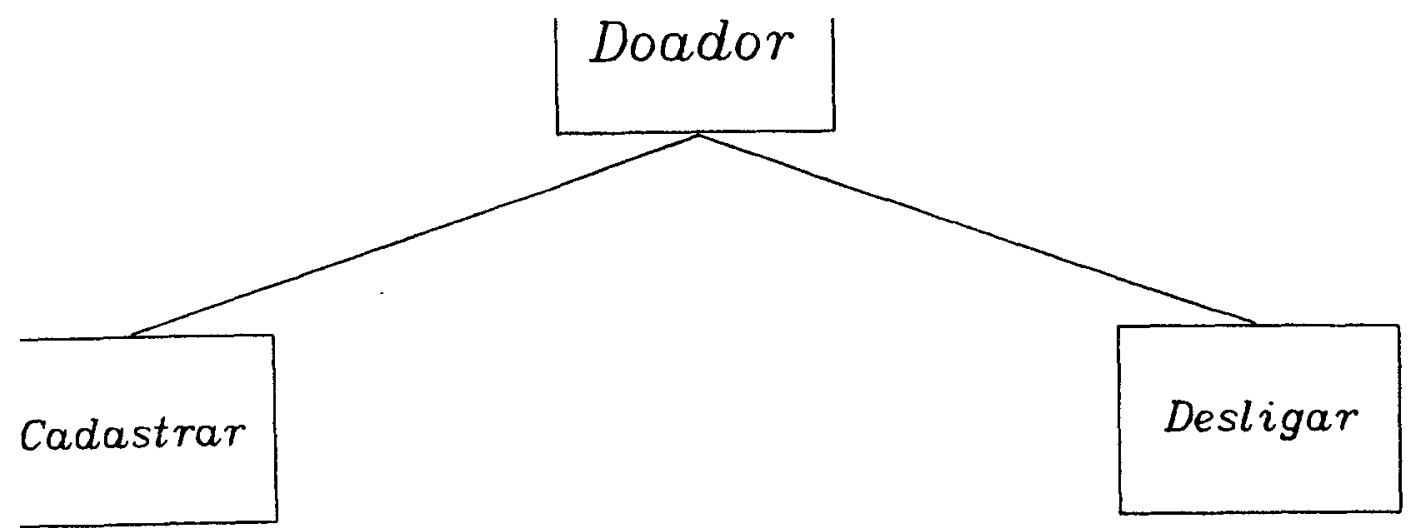

Figura B.6: Doador: Diagrama de Estrutura Cronológica

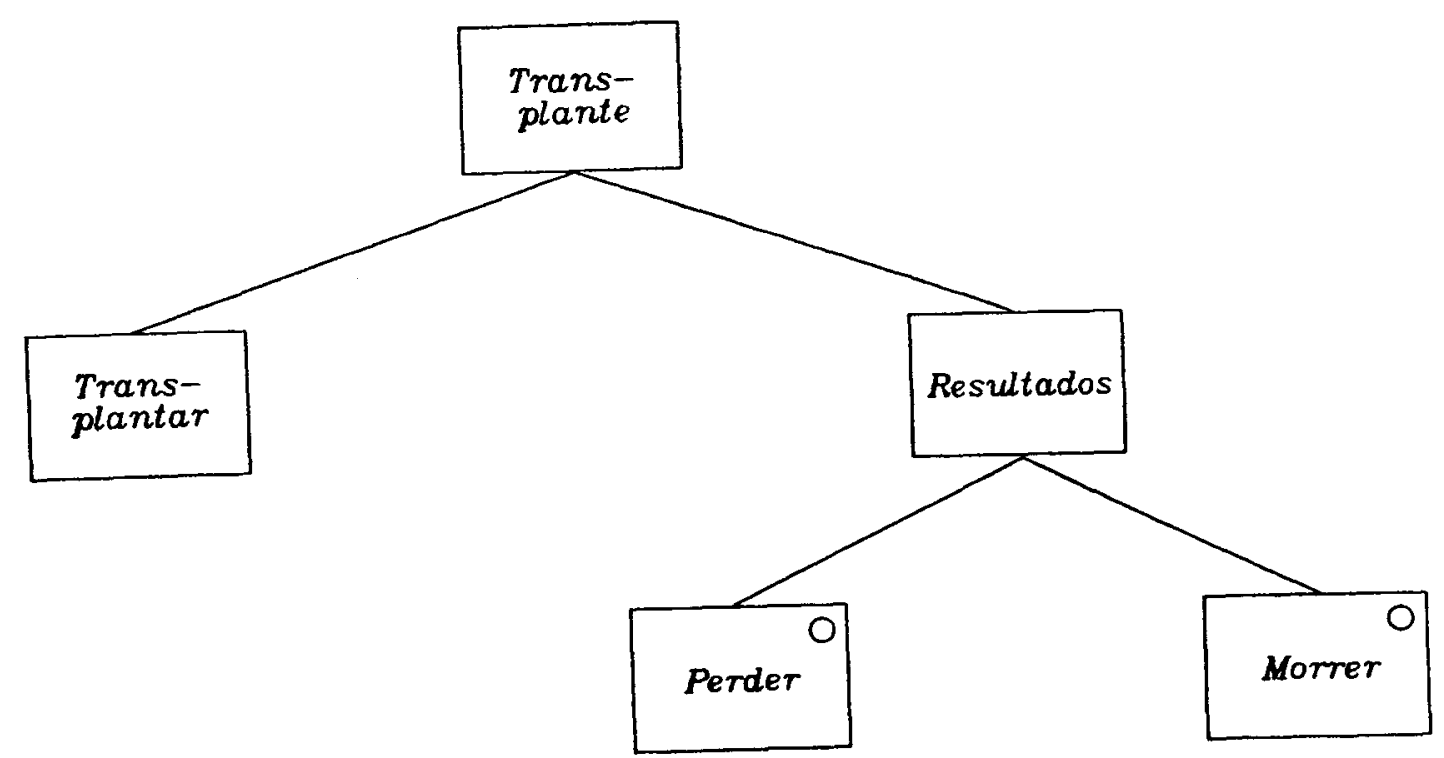

Figura B.7: Transplante: Diagrama de Estrutura Cronológica 
Estrutura Cronológica B.4.4 Suspensão de Receptor

SUSPENSÃO DE RECEPTOR iteração

SUSPENDER;

RETORNAR;

SUSPENSÃO DE RECEPTOR fim

Estrutura Cronológica B.4.5 Doador

DOADOR sequêencia

CADASTRAR;

DESLIGAR;

DOADOR fim

Estrutura Cronológica B.4.6 Transplante

TRANSPLANTE seqüência

TRANSPLANTAR;

RESULTADOS seleção

PERDER;

RESULTADOS alternativa

MORRER;

RESULTADOS fim

TRANSPLANTE fim

\section{B.5 Construção do Modelo Inicial}

O objetivo do modelo inicial é conectar o mundo real com os processos do sistema. A utilização de sufixos - -0 - nos nomes dos processos do mundo real e do sistema - -1 - tem como função tornar clara a distinção entre eles.

Existem basicamente duas formas de comunicação entre as entidades:

- Fluxo de Dados e

- Vetor de Estado. 
A comunicação por fluxo de dados ocorre quando alguém, ou algum processo, envia dados para uma entidade do sistema; esta, por sua vez, é responsável em executar as instruções necessárias para que as Bases de Dados, também chamadas de Vetores de Estado - VEs - reflitam a nova situação.

A comunicação por vetor de estado ocorre quando uma entidade do sistema processo de modelagem - resolve, por si mesma, consultar as Bases de Dados de outros processos para realizar alguma tarefa.

No caso do sistema em questão, as entidades do mundo real se comunicam com os processo de modelagem por fluxo de dados. Algumas ações tais como, consultas a vetores de estado, são bem óbvias e são acrescentadas ao modelo inicial Figura B.8. As siglas entre parênteses dadas a seguir constituem os vetores de estado ou fluxos de dados dessa figura.

Ao cadastrar um receptor, o VE de hospitais (hr) onde ele está cadastrado deve ser consultado para verificar a existência do hospital em questão.

Quando um hospital se desliga do sistema, o VE de receptores ( $\mathrm{rb}$ ) deve ser consultado, pois não deve ser permitida a retirada do hospital que esteja sendo utilizado por um receptor.

$\mathrm{Na}$ suspensão de hospitais, o VE de hospitais (sh) fornece as informações sobre o hospital sendo suspenso. Isto é necessário para não suspender um hospital não cadastrado. 0 mesmo se aplica a suspensão de receptores (sr).

Quando um transplante é efetuado, o VE do receptor (rt) é consultado para verificar se ele não está impedido de ser transplantado. $\mathrm{O} V E$ do doador (dt) é verificado, pois um doador pode doar no máximo dois rins. Deve também ser verificado o VE de suspensão de hospitais (st), de forma a não permitir o transplante em doadores pertencentes a hospitais suspensos. Na efetivação do transplante, o processo de modelagem "Transplante-1" envia um fluxo de dados (ir) para "Receptor-1", pedindo que ele incremente o número de transplantes que foram efetuados no receptor.

\section{B.6 Adição de Funções}

Nesta fase do método, o modelo inicial é completado, adicionando-se os processos que fornecem os relatórios e as demais as funções que são necessárias aos usuários.

Após conversar com os usuários do SPIT, alguns dos processos funcionais neces- 


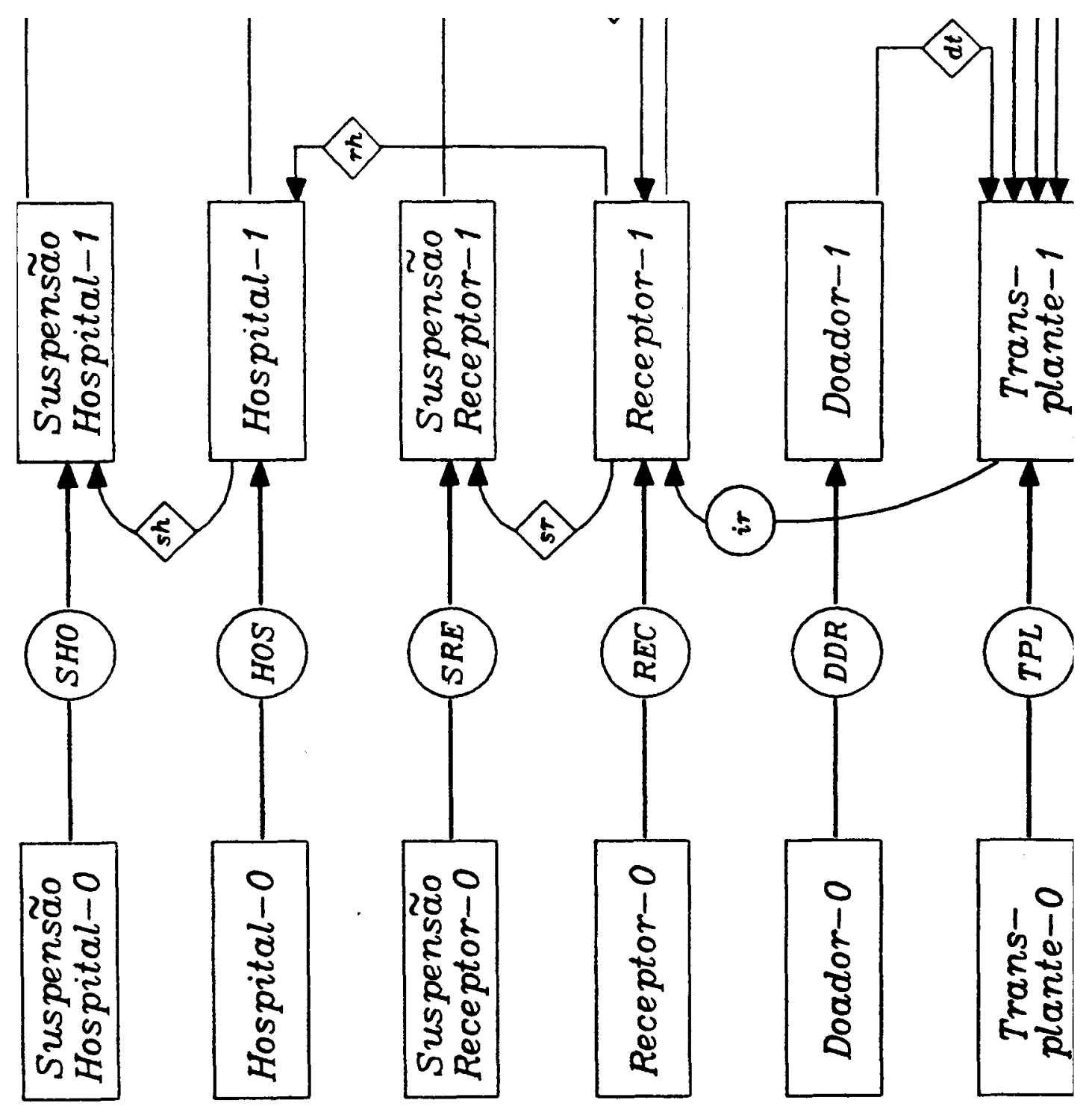

Figura B.8: Diagrama de Especificação do Sistema: Modelo Inicial 


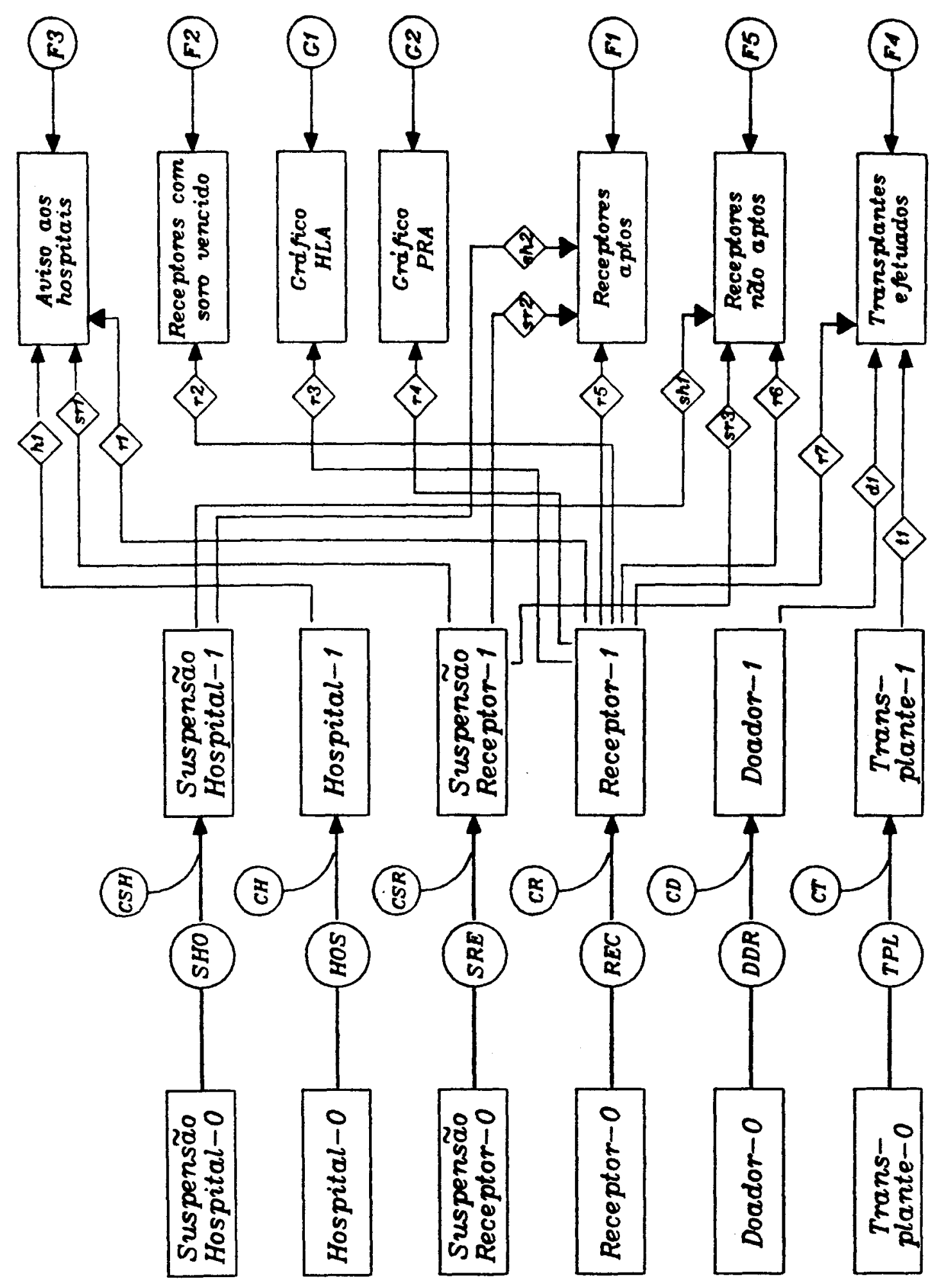

Figura B.9: Diagrama de Especificação do Sistema: Processos Funcionais ' 
sários ao sistema $O R I O N$ são os seguintes:

- C1: Para todas as entidades, exibir seus dados para simples conferência.

- F1: Relação dos possíveis receptores (que estão aptos a receberem um transplante) cadastrados no sistema.

- F2: Relação dos receptores com soro vencido.

- F3: Cartas de aviso aos hospitais que possuem receptores que não estão participando do processo de alocação por um motivo qualquer.

- F4: Relação dos transplantes já efetuados, incluindo dados dos doadores e dos receptores.

- F5: Relação dos pacientes que não estão aptos a serem selecionados para transplante.

- G1: Porcentagem da população de receptores que apresenta (0-100\%) que apresenta loci $H L A$ idênticos a um determinado doador. Gráfico de barras.

- G2: Porcentagem da população de receptores que apresenta PRA entre intervalos definidos pelo usuário.

Gráfico de barras.

- G3: Frequêencias absolutas e relativas dos loci HLA da população de receptores.

Gráfico de linhas.

De modo a não tornar o Diagrama do Modelo Inicial muito denso, as comunicações já mostradas na Figura B.8, página 129 são removidas. A adição de processos funcionais é mostrada na Figura B.9. As consultas simples (C1) serão implementadas nos próprios processos de modelagem.

\section{B.7 Articulação Temporal}

Neste passo de JSD, são consideradas as restrições de tempo que o sistema deve obedecer de forma que a implementação funcione adequadamente. Essa fase é necessária, por exemplo, quando partes do sistema são implementadas em módulos de processamento imediato - "on-line" - e outras em processamento por lotes - "batch". Como todos os processos do sistema proposto estão sendo implemen'tados em módulos de processamento imediato, está fase não foi necessária. 


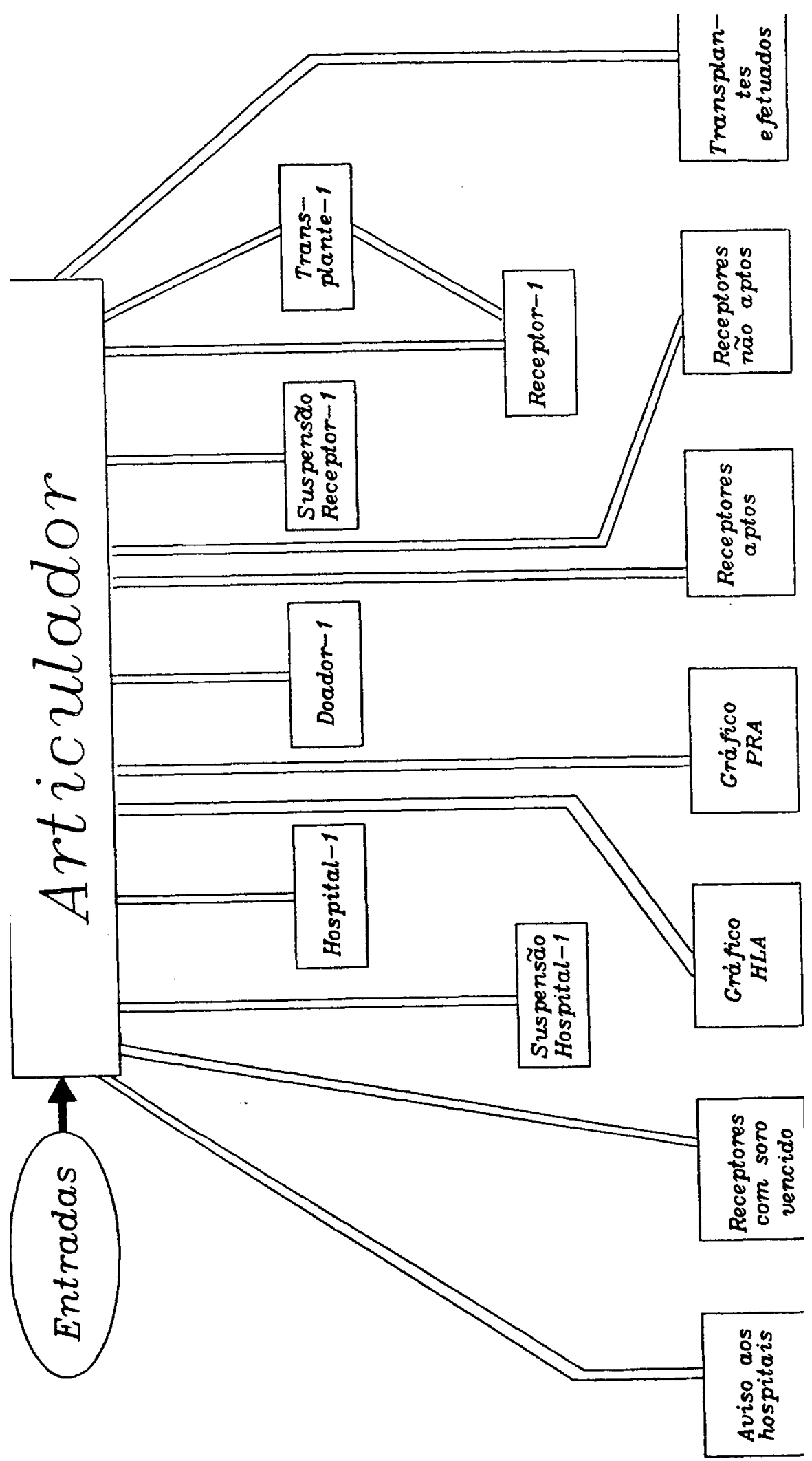

Figura B.10: Projeto da Implementação do Sistema 


\section{B.8 Projeto da Implementação do Sistema}

Esta fase consiste em transformar o Diagrama de Especificação do Sistema numa hierarquia de processos. Esses processos são controlados por um programa principal - o Articulador - como mostra a Figura B.10. Nessa figura, processos na parte superior chamam os processos de níveis inferiores (e.g. 0 processo Articulador chama o processo Transplante-1).

\section{B.9 Considerações Finais}

Neste apêndice foram descritas as várias fases do método JSD, aplicando-as ao Sistema de Base de Dados da aplicação $\mathcal{O} R \mathcal{I O N}$. Esse método foi escolhido pela facilidade que oferece em captar o dinamismo do sistema sendo projetado.

Embora esse método - voltado para projeto de sistemas [Pressman 87] - tenha sido muito útil no desenvolvimento de $\mathcal{O} \mathcal{R} \mathcal{I} \mathcal{N}$, foi realmente um processo cansativo e pouco criativo a elaboração manual dos vários grafos em cada fase de JSD.

Devido à falta de recursos na Universidade de São Paulo, não foi possivel a utilização de ferramentas automatizadas [Cameron 86] para a elaboração do projeto do Sistema de Base de Dados que integra a aplicação $\mathcal{O R I O N}$. 